\title{
QUELLEN UND LITERATUR
}

Im Quellenverzeichnis werden die konsultierten Archivalien nach ihren Fundorten und ebenso wie die benutzten Texte nach Ländern geordnet aufgelistet. Anonyme Schriften werden nach dem ersten Substantiv im Titel eingeordnet. Unter Periodika werden die wichtigsten und am häufigsten konsultierten Zeitschriften aufgeführt. Die Bibliographie erfaßt den Stand vom Sommer 2002.

\section{Quellen}

\section{Hilfsmittel}

Allgemeine Deutsche Biographie [ADB], hg. v. der Historischen Kommission der Akademie der Wissenschaften, 56 Bände mit Nachträgen und Generalregister, Berlin ${ }^{2}$ 1967-1971.

Neue Deutsche Biographie [NDB], hg. v. der Historischen Kommission bei der Bayerischen Akademie der Wissenschaften, bisher 20 Bände [bis »Püterich «], Berlin 1953-2001.

CASSElle, Pierre (Hg.), Bibliographie des publications officielles de la ville de Paris et du département de la Seine, Teil 1: 1800 à 1848, Paris 1991 und Teil 2: février 1848 à décembre 1859, Paris 1995.

Conseil Municipal de Paris. Rapports 1871-1966. Rapports et documents présentés au Conseil Municipal. Tables.

Conseil Général de la Seine. Catalogue des rapports \& Propositions imprimés et Table 1875 à 1919, Paris 1924.

Dictionnaire biographique et géographique du nationalisme français (1880-1900). Boulangisme, ligue des patriotes, mouvements antidreyfusards, comités antisemites, hg. v. Bertrand JOLY, Paris 1998.

Dictionnaire de Biographie Française, bisher 19 Bände [bis La-], Paris 1929-1995.

The Concise Dictionary of National Biography. From earliest times to 1985, 3 Bände, Oxford 1992.

Deutsche Biographische Enzyklopädie [DBE], hg. v. Walter KILLY und Rudolf VIERHAUS, 10 Bände, München u.a. 1995-1999.

Generalregister zu den stenographischen Berichten über die Verhandlungen und den amtlichen Drucksachen des konstituierenden Reichstages des Norddeutschen Bundes, des Deutschen Zollparlaments und des Deutschen Reichstages vom Jahre 1867 bis 1894/95, Berlin 1896.

Index to the House of Commons Parliamentary Papers 1801-1995/96, CD-Rom 1997.

Palmer's Index to The Times, CD-Rom 1999.

Public Record Office Guide, London 1997.

Stenographische Berichte über die Verhandlungen der durch die Allerhöchste Verordnung (...) einberufenen Häuser des Landtages. Haus der Abgeordneten, Berlin 1848/49 bis 1918, Register.

Wellesley Index to Victorian Periodicals 1824-1900, CD-Rom-Version.

Who's who of British Members of Parliament. A Biographical Dictionary of the House of Commons, Bd. 1 (1832-1885), hg. v. Michael STENTON, Hassocks 1976 und Bd. 2 (18861916), hg. v. DEMS. und Stephen LEES, Hassocks 1978 
WIKENS, Andreas, Archivführer Paris 19. und 20. Jahrhundert. Zentrale Bestände zu Politik, Wirtschaft und Gesellschaft in Archiven und Bibliotheken, Sigmaringen 1997 (DHIP Instrumenta, 2).

\section{Französische Quellen}

\subsection{Archivalien}

Archives Nationales, Paris

$\mathrm{F}^{\mathrm{lc}}$ I Ministre de l'Intérieur. Esprit public, élections, Conseils Généraux, Conseils d'Arrondissement. Hommages publics.

$F^{\text {le }}$ I 167 Seine: Paris $1830-1859$

- 23 mai-15 juillet 1850 . Autorisation d'ériger une statue, dans la cour du Val-de-Grâce, au Baron Larrey.

$F^{\text {ic }}$ I 168 Seine: Paris $1860-1882$

- 1860-1870. Projet des décrets du 25 avril 1860 et 19 mars 1870, autorisant l'érection de statues à Parmentier et à Vauquelin.

- 8 mars 1878-avril 1879. Projet d'érection d'une statue à la mémoire de l'astronome Leverrier.

- 5 avril-14 mai 1878. Érection d'une statue à Alexandre Dumas.

- 11 mai 1878. Érection d'une statue à Voltaire.

- 1878/79. Érection d'une statue de la République, place du Château d'Eau.

- 16 mars-23 avril 1880. Décret autorisant l'érection d'une statue à Pinel à la Salpétrière.

- 1881. Érection d'une statue à Coligny au chevet du Temple de l'Oratoire.

- mars 1882-févr. 1884. Érection d'une statue à Ledru-Rollin, place Voltaire.

$F^{\text {le }}$ I 169 Seine: Paris 1883-1895

- 7-26 juillet 1884 . Autorisation d'ériger une statue à Diderot.

- 27 nov. -12 déc. 1884 . Érection d'un monument à Gambetta.

- 24 juin 1885-27 oct. 1886. Érection d'une statue à Louis Blanc (place Monge).

- 2-30 juin 1883. Autorisation d'ériger un monument à Lamartine.

- 13 déc. 1886-21 mars 1887. Érection d'une statue à Étienne Dolet.

- 30 déc. 1887-3 mars 1887 et 3 juillet 1891 . Érection d'une statue à Danton.

- 22 juin-13 juillet 1888 . Érection d'une statue à Shakespeare.

- 27 juillet-28 août 1888 . Érection d'une statue à Condorcet.

- 20 oct. -24 déc. 1888 . Érection d'un monument à Raspail.

- 13 juillet-9 oct. 1889. Érection d'une statue à Alphonse Neuville.

- I8 avril 1890-31 jan. 1891. Érection d'une statue à Beaumarchais.

- 11 févr. 1891-18 mai 1899. Enlèvement et réinstallation de la statue de Marat par Baffier.

$F^{\mathrm{lc}}$ I 170 Seine: Paris 1896-1908

- 23 déc. 1883-14 août 1895. Délibération du conseil municipal demandant d'érection d'un monument aux fédérés fusillés en 1871 .

- févr.-2 mars 1896. Constitution d'un comité départemental en Mayenne pour l'érection à Paris d'un monument à Pasteur.

- 10 sep.-18 déc. 1896. Érection d'un monument à la mémoire d'Eugène Flachat (ingénieur).

- 11 déc. 1896-2 juin 1897. Érection d'un monument à Victor Hugo.

- 30 déc. 1896-5 mai 1897. Érection d'un monument à François Garnier.

- 20 avril-14 juin 1897. Projet d'un monument à Pelletier et à Caventou.

- 22 nov. -21 déc. 1897 . Érection d'un monument à Lavoisier.

- 30 déc. 1898-29 mai 1902. Érection d'un monument à Jules Simon. 
- 21 juin-22 nov. 1901. Érection d'un monument à Baudin.

- 31 déc. 1902-30 mai 1903. Érection d'un monument à Pasteur.

- mai 1904-21 juillet 1905. Érection d'un monument au chevalier de La Barre.

- 29 nov. 1905-27 mars 1906. Érection d'un monument à Charles Floquet.

- 11 juin-20 sep. 1906. Érection d'un monument à Ludovic Trarieux, ancien sénateur.

- 26 juin-16 juillet 1907. Érection d'un monument à Garibaldi.

- 8 juillet $1907-1^{\text {er }}$ févr. 1908. Érection d'un monument à Michel Servet.

- 12 juillet-22 oct. 1907. Érection d'un monument à Louis Ratisbonne.

- 10 juillet 1908-23 janv. 1909. Érection d'un monument au docteur Péan.

- 17 déc. 1909-23 avril 1910. Érection d’un monument à François Coppée.

$\mathrm{F}^{21}$ Beaux-Arts

$\mathrm{F}^{21} 566$ Bulletin des Beaux-Arts (1877-1878) (...). Concours pour la figure de la République (1848). 1828-1878.

$\mathrm{F}^{21} 576$ Monuments et édifices parisiens et départementaux. Monuments parisiens: Colonne

Vendôme et Église de la Madeleine. Encouragements et souscriptions. An XII-1876.

$\mathrm{F}^{21} 583$ Statue de Louis XIV, place des Victoires, et monument du maréchal Ney. 18161854.

$F^{21} 757$ Bâtiments civils et Palais nationaux. Colonne de Juillet 1851-1879. Colonne de la place Vendôme 1852-1879.

$\mathrm{F}^{21} 814$ Palais du Louvre. 1852-1865.

$F^{21} 1375$ Colonne Vendôme. 1815-1875.

$\mathrm{F}^{21} 1509$ Palais du Louvre. 1848-1852.

$F^{21} 1566$ Monument de Courbevoie (Napoléon $I^{\text {er) }}$ 1863-1871 (...) Monument du maréchal Ney 1898.

$F^{21} 4845$ à 4868 Attributions en dépôt et concessions d'Euvres d'art, décorations d'édifices publics, monuments commémoratifs 1811-1945. Attributions: classements par départements et par villes. Paris 1820-1945.

$\mathrm{F}^{21} 4849$

- Statue de Denis Papin, destinée au Conservatoire des Arts et Metiers, 20 nov. 1885-17 jan. 1890.

$\mathrm{F}^{21} 4853$ [Jardin du Luxembourg]

- Monument St. Beuve, $1^{\text {et }}$ févr. 1897-11 jan. 1899.

- Monument Scheurer-Kestner, 17 mars-29 juillet 1909, restauration.

- Monument de Madame de Ségur, 16 mai 1908-15 avril 1909.

- Monument du poète Gabriel Vicaire, 27 oct. 1901-29 mai 1902.

- Monument Raffet, peintre, 29 déc. 1891-20 nov. 1895.

- Monument Meissonier, 22 juillet 1891-31 mars 1896.

- Hôtel des Invalides, Statue de Napoléon I ${ }^{\text {et }}$ par Seurre, 20 nov.1914-28 août 1915.

- Monument Waldeck-Rousseau, 6 mars 1906, 4 déc. 1904-15 mai 1926.

$\mathrm{F}^{21} 4854$

- Monument Arthur Ranc, journaliste, 24 déc. 1910-19 févr. 1916.

$\mathrm{F}^{21} 4855$

- Monument à la Mémoire de Béranger, poète, 16 févr. 1879-12 mai 1885.

- Monument à Maurice Berteaux, 20 jan. 1914.

- Statue de Bobillot, 6 juillet 1888-10 sep. 1928.

- Monument de Sardi Carnot, et de l'alliance franco-russe, 18 oct.-27 nov. 1913.

- Monument Camille Desmoulins, 22 sep. 1905-10 août 1906, Palais Royal.

- Monument au Général Alexandre Dumas et Monument Alexandre Dumas fils, 25 sep.- 24 déc. 1895.

- Monument de la femme française de 1870-1871, 20 avril-22 juillet 1909.

- Monuments Floquet, (1) 23 mars 1907-16 sep. 1908, (2) 9 juillet 1898-13 déc. 1901.

- Statue de Galilée, 23 mars 1900. 
- Monument à Garibaldi, 30 nov. 1906-14 juin 1912.

- Monument Francis Garnier, 13 mars 1895-8 oct. 1900.

- Monument Baudin, 7 oct. 1901-4 sep. 1902.

- Monument Victor Hugo, 4-14 oct. 1889.

- Monument Victor Hugo, 27 oct. 1897-3 févr. 1902.

$F^{21} 4856$

- Monument Chevalier de La Barre, avril 1906-21 jan. 1919.

- Monument Le Royer, par Houdain, 4 févr.-15 avril 1899.

- Monument George Sand, 24 juin 1904-8 août 1905.

- Monument de Mme Staël, statuaire, 3 mars-2 juillet 1909.

- Monument à Philippe Pinel, médecin, 17 sep. 1877-31 août 1884.

- Statue de Nicolas Leblanc, 8 mars 1885-22 jan. 1886.

- Monument Lamarck, 29 avril 1907-9 avril 1910.

- Monument Pelletier et Cavantou, Bld. Saint Michel, 24 déc. 1900-8 juillet 1902.

- Monument Parmentier et Vauquelin, cour de l'École de Pharmacie, 20 jan. 1869-18 nov. 1875 .

- Monument à la mémoire de Parmentier, 25 nov.-11 déc. 1884

- Monument à la mémoire d'Alphonse de Neuville, peintre, 12 mars 1888-7 déc. 1889.

- Monument à la mémoire de Le Verrier, 25 juin 1878-7 jan. 1879.

- Monument J.J. Rousseau, sur la Place du Panthéon, 8 déc. 1881-25 jan. 1893.

- Monument Clémence Royer, 15 sep. 1907-12 mars 1928.

- Monument à la mémoire de Théophile Renaudot, fondateur du journalisme parisien.

- Monument à la mémoire d'Henri Regnault, et des élèves tués pendant la guerre de 18701871/pendant le siège de Paris, sur le portique d'École Nationale des Beaux Arts.

- Monument de F.V. Raspail, 28 juin 1888-18 juillet 1889.

$\mathrm{F}^{21} 4857$

- Monument Trarieux, 25 juin 1906-4 juillet 1907.

- Monument Émile Zola, 3 juin 1910-2 juin 1914.

$F^{21} 4860$

- Statue de Lavoisier, 21 juillet 1894-9 juillet 1900.

- Place Malesherbes: square, Monument à la mémoire d'Alexandre Dumas, 5 déc. 1881-13 avril 1883.

- Place Voltaire: Monuments de Ledru Rollin, 10 févr. 1882-14 mars 1885.

AJ52 493 Fonds des archives de l'École Nationale Supérieure des Beaux Arts. Concours et expositions extérieurs à l'École. (Concours indépendants). Exposition à l'École des Euvres et des concurrents 1829-1855. (...)

Archives de Paris

V.M Édifices Municipaux

V.M 91 Monuments divers.

V.M 92 Statues et Fontaines.

V.M 92/1 Affaires générales.

V.M 92/2-5 Statues de Paris par ordre alphabéthique des rues et des places.

V.R 161 Concours pour l'érection du monument allégorique à Courbevoie. Défense de Paris (1879).

V.R 162 Concours pour la statue de la place de la République (1879).

Direction des Affaires culturelles, Paris [Dossiers]

- Jeanne d'Arc, Place St. Augustin u. Jeanne d'Arc, Place des Pyramides

- Jeanne d'Arc, Bld. Saint Marcel

- Jules Ferry

- Ledru-Rollin 
- Waldeck-Rousseau

- La République (de Soitoux)

- Sadi-Carnot

- Camille Desmoulins, statue.

\subsection{Gedruckte Quellen}

Affaire de la souscription [Alphonse] Baudin. [Appel.] Seul compte rendu complet, recueilli par la sténographie et revu par les défenseurs, Paris 1868.

Anniversaire de la mort de Napoléon-le-Grand, détails interéssants sur la statue de l'empereur qui doit être placée sur la colonne de la Place Vendôme, o. O. o. J.

Association patriotique de Jeanne d'Arc, Paris 1890.

AUBRY-VÉZAN, La Barrière de Clichy au Maréchal Moncey à l'occasion de l'érection du monument de la Place Clichy, Paris o. J.

D'AVRAY, Maurice, Le procès du chevalier de La Barre: un crime judiciaire et une erreur d'opinion d'après les documents authentiques, préface de Henry DE GOUDOURVILLE, Paris 1908.

BADER, Louise, La couronne civique. À la mémoire de Henri Regnault et des combattants morts pour la France 1870/71 dans la guerre de 1870/71, Paris 1872.

BARTHÉLEMY, Charles, Erreurs et mensonges historiques, Bde 14 und 15, Paris 1881 und 1882.

- Erreurs et mensonges historiques. Le chevalier de la Barre, quatorzième série, Paris 1881.

BAvoux, Évariste, Les Monuments à Paris. La Colonne Vendôme et Jeanne d'Arc, Paris 1874.

BÉRgerat, Émile, Sauvons Courbet! Paris 1871.

BLONDEL, Jehan, Saute Marianne!, Paris 1880.

BLOU, Alexandre, Fête nationale du 14 juillet 1883. Érection de la statue de la République, Paris 1883.

BolleaU (Fils), Louis-Charles, Dédié à M. Spuller, député, président du conseil d'execution. En passant devant le monument Gambetta (signé: L'architecte L.C.B., fils), Paris 1888.

-, Monument Gambetta. Souscription et programme. Commentaire du projet Aubé-Boileau et Monographie, par l'architecte B., Paris, o. J. [1890].

BOULMIER, Joseph, Estienne Dolet. Sa vie, ses Euvres, son martyre, Paris 1857

[BourgeoIS, Paul,] La Colonne Vendôme. 18 mai 1871 [signé: Un Vendéen] o. 0. [Versailles] 1871.

BOURGIN, Georges, Gabriel HENRIOT (Hg.), Procès verbaux de la Commune de 1871, 2 Bde, Éd. critique, Paris 1924.

BOURNEVILLE, Étienne Dolet. Sa vie, ses œuvres, son martyre. Conférence faite le 18 mai 1889 à la mairie du $V^{e}$ arrondissement à l'occasion de l'inauguration de la statue d'Étienne Dolet sur la place Maubert. Par le citoyen B., député de la Seine, Paris 1889 (Société de la Libre-pensée du $\mathrm{V}^{\mathrm{e}}$ arrondissement (Groupe Étienne Dolet).

BOUTEILLER, E. de, Notes iconographiques sur Jeanne d'Arc, Paris 1879

CAHEN, Albert, Note sur Denis Papin à l'occasion de l'inauguration de sa Statue au conservatoire nationale des Arts et Métiers, par A.C., vice-président de la Société (Extrait du Bulletin Administratif N/2 1887; Société des anciens élèves des Écoles Nationales d'Arts et Métiers), Paris o. J.

CASTAgnary, Jules-Antoine, Gustave Courbet et la Colonne Vendôme. Plaidoyer pour un ami mort, Paris 1883.

CastellaNt, Auguste, Centenaire de la Révolution, Jean-Jacques Rousseau. Hommage national, Paris 1887

[CASTELlaNT,] La Statue de Jean-Jacques Rousseau, o. O. o. J. [Asnières 1890]. 
Cérémonie de la Sorbonne en l'honneur de Jules Ferry (20 décembre 1906), Corbeil 1907.

ChampVILle, Gustave Fabius de, Camille de Desmoulins. Précis historique en vers dit par l'auteur à l'inauguration de la statue de C. D., le 22 Septembre 1905 au Palais-Royal, Paris 1905.

CHÉRY, Ph., Notes analytiques sur la statue équestre de Henri IV, érigée en bronze, sur le terre-plain du Pont-Neuf, à Paris, Paris 1819.

Le Chevalier de la Barre. Son procès, ses bourreaux, o. O. 1905.

Aux trois grands citoyens. Grévy, Gambetta, Victor Hugo. La France reconnaissante, Paris 1880

La Colonne. L'anciene statue de Napoléon et la nouvelle, o. O. o. J. [28 juin 1833].

Colonne Vendôme. Monument triomphal commencé le 25 août 1806, terminé le 15 août 1810 , Paris 1858.

La Colonne Vendôme, Paris o. J. (1863).

Comité international de la statue d'Auguste Comte, Paris o. J.

Comité du Monument Waldeck-Rousseau. 17 Rue de la Rochefoucauld, Paris, 6 juillet 1910.

Comité national du centenaire de 1848 . Procès-Verbaux du gouvernement provisoire et de la Commission du pouvoir exécutif, 24 février-22 juin 1848, hg. Charles $\mathrm{H}$. POUTHAS u. Albert SOBOUL, Paris 1950.

Compte rendu des travaux de la commission de souscription pour le monument de Larrey érigé au Val-de-Grâce, le 8 août 1850, Paris 1850 (suivi de treize discours prononcés à l'inauguration du monument).

Concours pour l'érection d'un monument à Danton. Rapport général sur les opérations du Jury, Paris 1890 (Ville de Paris).

Conseil Municipal de la Ville de Paris. Procès-verbaux des débats 1871-1914, 70 Bände.

Conseil Municipal de la ville de Paris. Rapports et documents présentés au Conseil Municipal de Paris 1871-1918, Paris 1871-1918, 47 Bände.

Courbet. Rapport authentique. Conduite et agissement du peintre Courbet sous le gouvernement du 4 septembre, et sous le gouvernement du 18 mars, dit la Commune de Paris, à propos de la conservation des arts, et de la colonne Vendôme, 1871, in: Louis ARAGON, L'exemple de Courbet, Paris 1952, S. 56-63.

Dalou - sa vie et ses Euvres. Le Triomphe de la République. Inauguré solonellement par la Ville de Paris le 19 novembre 1899, Paris 1899.

DANIEL, Alphonse-Exupère, abbé [vicaire à Saint-Nicolas de Chadonnet], Dolet. Sa statue place Maubert. Ses amis. Ses ennemis, Paris 1889.

Darc, Jeanne, in: Pierre LAROUSSE, Grand dictionnaire universel du $\mathrm{XLX}^{\mathrm{e}}$ siècle français, historique, géographique, mythologique, bibliographique, littéraire, artistique, scientifique, Bd. 6, $1^{c}$ partie, Paris [1870] ND 1982, S. 106-115.

DELABORDE, Le Vicomte Henri, Sur la déstruction récente de quelques monuments de l'art, à Paris [lu dans la séance publique annuelle des cinq Académies le mercredi 25 oct 1871], Paris o. J.

[DESCHAMPS, F.,] Oraison funèbre à la mémoire des gardes nationaux morts pour la République. Monument commémorative élevé à leur gloire place Vendôme, en remplacement de la Colonne, Paris o. J. [1871].

Description de la Colonne de la Grande Armée et de la statue du général Desaix, o. 0 . o. J. [1810].

Description de la nouvelle statue de Henri IV avec un fac-simile de l'écriture de ce bon roi, Paris 1819.

Description de la statue équestre de Henri IV sur le Pont Neuf ou détails intéressants sur les anciennes et nouvelles statues équestres de ce Prince, Paris 1820.

DESNOYERS, F. E., L'iconographie de Jeanne d'Arc, Orléans ${ }^{2} 1893$.

DESTOUCHES, Émmanuel, [Le Gros fermier de la France.] Le Monument des Héros, Février 1848. 
Détails sur la cérémonie qui va avoir lieu au Marché des Carmes (12 $2^{\mathrm{e}}$ arrondissement), à l'occasion de l'inauguration du buste du Prince Louis-Napoléon, Président de la République, Paris o. J.

Discours prononcé à l'inauguration de la statue de Le Verrier le jeudi 27 juin 1889, Paris 1889.

Discours prononcés à l'inauguration du monument élevé à la mémoire de Marcelin Berthelot à Paris, Le dimanche 20 mai 1917, Paris 1917 (Institut de France).

Discours prononcés à l'inauguration du monument élevé à la mémoire de Pasteur à Paris, le samedi 16 juillet 1904, Paris 1904 (Institut de France).

Discours prononcés à l'occasion de l'inauguration de la Statue Du Maréchal Ney, surnommé le Brave des Braves, Paris o. J.

Discours prononcés à l'occasion de l'inauguration de la statue de Le Verrier sous la présidence de M. Fallières à l'observatoire de Paris, le jeudi 27 juin 1889, Paris 1889 (Institut de France. Académie des Sciences).

Dithyrambe. Réinstallation de la statue de Napoléon sur la Colonne de la Place Vendôme, le 18 juillet 1833, Paris 1833.

DROUYN DE LHYS, Projet d'élever une statue à Daubenton, Rapport fait à la Société dans la séance du 3 mai 1861, Paris 1861 (Société impériale zoologique d'acclimatation).

DuPanlouP, Félix-Antoine Philibert, Mgr. [Évêque d'Orléans], Premières lettres à MM. les membres du Conseil muncipal de Paris sur le Centenaire de Voltaire, Paris 1878.

[DUPIN,] Discours de M. Dupin, prononcé à la cérémonie de l'inauguration de la statue du maréchal Ney, sur l'esplanade du Luxembourg, le 7 décembre 1853, Paris o. J. [1853].

DURAND, Hippolyte, Notice biographique sur Napoléon I ${ }^{\text {er }}$. Détails sur l'érection de sa statue en Empereur romain sur la colonne de la Grande Armée, Paris 1863.

Enquête Parlementaire sur l'insurrection du 18 mars. Rapport de la Commission. Édition contenant in extenso les trois volumes distribués à L'Assemblée Nationale, Paris 1872.

FABRE, Jospeph, Jeanne d'Arc. Libératrice de la France, Paris o. J. [1883].

- Les bourreaux de Jeanne d'Arc et sa fête nationale. Notices sur les personnages du procès de condamnation. Documents sur la fête du patriotisme, Paris 1915.

FAURE, Étienne, Où sera érigé sa statue?, par É.F., disciple de Raspail, Paris o. J.

FAUVEZ, H., Projet de tombeau pour l'Empereur Napoléon Premier par Louis Auvray, statuaire. Dédié à sa Majesté l'Empereur Napoléon III, Paris 1861.

FÉlD, Maurice, Le régime administratif du département de la Seine et de la Ville de Paris, Paris ${ }^{3} 1945$.

FrançoIS, L., Diderot. Lettres à M. Bizot de Fonteny à propos de l'érection de la statue de Diderot, Langres 1884.

[FRETTÉ, P.,] La Statue de Voltaire. Qui la paiera? Songe d'une nuit d'été dédié à M. de St.e Beuve, par P.F., Paris 1868.

GAIPOUR, E., Récits nationaux et patriotiques. Extraits des grands chroniqueurs et des grands historiens, Paris o. J. [1883].

GALLET, Valentin, La statue du dieu Voltaire, Paris 1867

GARSOU, Jules, Béranger et la légende napoléonienne, Bruxelles 1897.

—, Les créateurs de la légende napoléonienne. Barthélemy et Méry, Bruxelles 1899.

- L'Évolution napoléonienne de Victor Hugo sous la Restauration, Paris 1900.

GoIs, Étienne-Pierre-Adrien, Projet de monument et fête patriotique [précédé d'une dédicace à NN. SS. les représentants de la nation], Paris o. J.

GromiER, (M.)-A., En l'honneur de Garibaldi (à propos de sa campagne en France), Paris 1891 (signé: oct. 1879).

GULLAUME, Concours pour l'exécution d'un buste de la République et d'une face de médaille représentant les figures de la République et de la ville de Paris. Rapport présenté au nom du jury chargé du classement des esquisses, Paris 1879 (Ville de Paris). 
-, Concours pour l'érection place de la République d'une statue monumentale de la République. Rapport présenté au nom du jury chargé de juger les modèles admis au second degré du concours, Paris 1880 (Ville de Paris).

HAMEL, Ernest, La statue de Jean-Jacques Rousseau. Paris ${ }^{2} 1868$.

[HATIN, Eugène,] Enfin! Théophraste Renaudot. Aura-t-il la Statue qu'il mérite à tant de titres! L'absolue vérité sur sa vie et ses (Euvres, outrageusement défigurées depuis deux siècles par la calomnie \& l'ignorance, par l'Histoire de la Presse, Paris 1892.

D'HENRIET, Ch., La statue de Voltaire, Paris 1868, Extrait de la Philosophie positive, maijuin 1868 .

HILAIRE DE BARENTON, Étienne-Marie Boulé, Le Tract populaire, illustré, Paris 1905-1914.

Histoire du Maréchal Ney, Duc d'Elchingen, prince de la Moskowa. Inauguration de sa statue, Lyon 1854.

Hommage d'un patriote aux défenseurs de la nation. Le coq gaulois, chant patriotique, Chaumont 1871 .

HOUDON, Réflexions sur les concours en général et sur celui de la statue de Jean-Jacques Rousseau en particulier, Paris o. J. [1791].

Hugo, Victor, À La Colonne de la Place Vendôme. Ode, Paris ${ }^{2} 1827$.

—, Souvenirs personnels 1848-1851, réunis et présentés par Henri GULLEMIN, Paris 1952.

[-,] Lettres à mon curé ( $1^{\text {er }}$ lettre). Les Processions par Un Ami de la Liberté. Suivi de l'Histoire du Supplice de Jean Calas et du supplice du Chevalier de La Barre, Orthez o. J. [1895].

[HUMBERT,] Proposition faite par la presse française pour l'érection d'un Monument élevé à la gloire de Napoléon III., Mirecourt 1883 [par H.].

Hus, Auguste, La Colonne de la Place Vendôme bourbonisée, Paris 1822 [1 ${ }^{\text {er }}$ septembre].

Inauguration du buste de Gabriel Vicaire, dans le Jardin du Luxembourg à Paris, le 23 octobre 1902. Discours et Vers, Bourg-en-Bresse 1902.

Inauguration du monument François Coppée à Paris, le 5 juin 1910 sur la place de SaintFrançois Xavier, Paris 1910.

Inauguration du monument élevé à Pierre Corneille, à Paris, le dimanche 27 mai 1906, Paris 1906.

Inauguration du monument érigé à Lavoisier par une souscription internationale sous le patronage de l'Académie des Sciences, le 27 juillet 1900, Paris 1900.

Inauguration du Monument élevé à la mémoire de Jean Macé et à la glorification de l'enseignement laïque, le vendredi 13 juillet 1900, Paris 1900.

Inauguration du Monument Péan, 16 décembre 1909, Paris 1909.

Inauguration du Monument élevé à la mémoire de Sainte-Beuve à Paris, le 19 juin 1898, Paris 1898 (Institut de France, Académie Française).

Inauguration de la statue de François Arago à Paris, le dimanche 11 juin 1893, Paris 1893.

Inauguration de la statue d'Alexandre Dumas à Paris, le mardi 12 juin 1906, Paris 1906.

Inauguration de la Statue du Baron Larrey, chirurgien en chef de la Grande Armée, dans la Cour d'honneur du Val-de-Grâce, le 8 aout 1850. Extrait du Moniteur Universel du 9 août 1850 .

Inauguration de la statue de Nicolas Leblanc à Paris le 28 juin 1887, Paris 1887 (Institut de France. Académie des Sciences).

Inauguration de la statue de Philippe Pinel sur la place de la Salpétrière, le 13 juillet 1885 , Paris 1885.

Inauguration de la statue de Théophraste Renaudot (1586-1653), Fondateur du Journalisme et des consultations charitables pour les pauvres malades, 4 juin 1893, sous la présidence de Charles Dupuy, président du Conseil des Ministres, Ministre de l'Intérieur, Paris 1893.

Inauguration de la statue de Voltaire, Paris 1885. 
Inauguration de la statue de Voltaire à 25 ans, 6 novembre 1887, offerte par l'auteur $M$. Émile Lambert à la ville de Paris et placée dans la cour de la mairie du $\mathrm{IX}^{\mathrm{e}}$ arrondissement. Discours pronocé par Ernest Dupré, Paris 1887.

Inventaire des richesses d'art de la France. Paris. Monuments civils, Paris, Bd. 1 (1879), Bd. 2 (1889).

Marquis de JAUCOURT, Jean François Le Visse de Montigny, Eugène BERSER (Hg.), Discours prononcés le mercredi 17 juillet 1889 pour l'inauguration du monument de l'Amiral Coligny, Paris 1889.

JOUN, Henry, Histoire et description de la colonne de Juillet, Paris 1879 bzw. in: Inventaire général des richesses d'art, Bd. 1, Paris 1879, S. 343-365.

LABITTE, Alphonse, À la Colonne 1882, Paris 1882.

LAFOLIÉ, Ch. J., Mémoires historiques relatifs à la fonte et à l'élévation de la statue équestre de Henri IV sur le terre-plein du Pont-Neuf à Paris, Paris 1819

LALOT, J.A., Devant la statue de Coligny, Paris o. J. [ [21890].

[LAPRADE Victor de,] Lamartine. Discours prononcé à la réunion publique du 2 mai 1869, au profit de la souscription pour la statue du poète, par V.d.L. (de l'Académie Française), Paris 1869.

LA SICOTIERE, Pierre François Léon, Le Centenaire de 1789, le monument de la Révolution, Nantes 1887.

LAZARE, Louis, Félix LAZARE, Dictionnaire administratif et historique des rues de Paris, Paris 1844, ND Paris 1994.

LEBLOIS, Louis, Discours prononcé à l'inauguration du monument de Scheurer-Kestner (11 février 1908), Paris 1908.

LEFEBRE, Andrée, 14 juillet 1878. Chant patriotique ... La Colonne de la Bastille, Paris o. J.

La Légende napoléonienne et ses renégats, Paris 1869

LEGRAND, J.-G., C.-P. LANDON, Description de Paris et de ses édifices, seconde édition corrigée et très augmentée, $\mathrm{Bd}$. 2, Paris 1842.

LEMIRE, Charles, Jeanne d'Arc et le sentiment national (1412-1431, 1870-18**). La Fête de la Patrie Française, Paris ${ }^{2} 1898$.

LEPRÉvOST, Maurice [i.e. Maurice MAIGNEN], La statue de Voltaire, Périguieux 1867.

LETELLIER, F., La culotte et le jupon. - Napoléon sur la colonne, Nancy o. J.

Lettre de Marie-Louise, ex-impératrice des Français, à S. M. Louis-Philippe ${ }^{\text {er }}$, roi des Français, concemant la statue de son illustre époux [Napoléon $I^{\mathrm{er}}$ ], relevée sur la colonne de la Place Vendôme, à la mémoire des Armées Françaises, 29 d'auguste 1834,0 . O. o. J.

LÉVĖQUE, Eugène, À propos de la Colonne Vendôme restaurée moins le couronnement et de la statue élevée à Jeanne d'Arc près des Tuileries, Paris 1874

Ligue Française pour la Défense de Droits de l'Homme et du Citoyen. Le Monument Trarieux, Paris 1904.

Ligue Française de l'Enseignement. Comité du Monument Jules Ferry. Cérémonie de la Sorbonne en l'honneur de Jules Ferry (20 Déc. 1906), Corbeil 1907.

LisSagaray, Prosper Olivier, Histoire de la Commune de 1871, Paris o. J.

[DE MARCËRE], Souvenir de la Fête Nationale du 30 juin 1878. Inauguration au Champ de Mars de la Statue de la République. Discours prononcé par M. de M., ministre de l'Intérieur, Paris 1878.

MARMOTTAN, Paul, Les statues de Paris, Paris o. J. [1886].

MichauX, L., Places, Squares, Avenues, II. Place de Clichy, in: Inventaire général des richesses d'art de la France. Paris. Monuments civils, Bd. 2, Paris 1889, S. 35/36.

MiCHELET, Jules, Histoire de la Révolution Française, Bd. 1, Paris 1847.

MISSET, E., Jeanne d'Arc champenoise. Étude critique sur la véritable nationalité de la Pucelle, d'après les documents officiels de son époque et les plus récentes publications, Paris 1893 [1895?]. 
MONTAGLION, Anatole de, Notice sur l'ancienne statue équestre. Ouvrage de Ricciarelli et de Biard le Fils, élevée à Louis XIII en 1639 au milieu de la Place Royale à Paris, Paris 1874.

MONTORGUEL, Georges, La vérité sur le Chevalier de la Barre, extrait du Journal Éclair, Abbeville o. J. [1906].

Un Monument à Béranger. Petit bonhomme vit encore! (signé: R.B.), Paris 1907.

Monument Marcelin Berthelot. Cérémonie de la Sorbonne 3 octobre 1908, Paris 1909.

Monument Courbet. Souscription nationale, Paris o. J. [1885].

Le Monument d'Alexandre Dumas, Euvre de Gustave Doré. Discours prononcé devant le monument le jour de l'inauguration. Poésies recitées le même jour sur différents théatres ou distribuées aux assistants avec une préface par $\mathbf{M}$. Alexandre DUMAS fils, Paris 1884

Le Monument de Ferdinand Fabre, 14 juin 1903, Paris o. J.

Monument de Victor Hugo. Médaillons de Charles Hugo, François-Victor Hugo, Paul Meurice, Auguste Vacquerie. Cérémonie d'Inauguration 20 juin 1910, Paris 1910.

Monument à la mémoire du baron Larrey le 8 août 1850 , Paris 1851 .

Monument élevé à Henri Regnault, pensionnaire de l'Académie de France à Rome et aux élèves de l'École des Beaux-Arts, morts sur les champs de Bataille 1870-1871, o. O. o. J.

Les Monuments de Paris après l'CEuvre de la Commune, Paris 1871.

MOREL, N. L., Description des nouvelle et ancienne statues de Louis XIV, inaugurées l'une le 28 mars 1686, et l'autre le 25 août 1822, Place des Victoires, o. O. o. J. [Paris, 1822].

La Mort de Napoléon, détails intéressants sur la statue de l'Empereur, qui doit être placée sur la colonne de la place Vendôme. Chant dédié aux braves compagnons de sa gloire [1833].

MOUROT, Victor-Antoine (abbé), Jeanne la bonne Lorraine et la grande Française. La Nationalité de Jeanne d'Arc. Réponse à l'étude de $\mathbf{M}$. l'abbé Misset `Jeanne la champenoise〈, $\mathrm{Pa}$ ris 1896.

Napoléon sur la Colonne. Programme des fêtes et cérémonies qui ont eu lieu les 17, 18, et 29 juillet dans Paris, o. O. o. J.

Napoléon, son fils et l'aigle au pied d'un trophée. Napoléon sur la colonne de la Place Vendôme. Le grand homme sur la colonne, o. 0. o. J. [1833].

Napoléon dans les cent Jours ou Le Portrait du Héros sur la Colonne de la Place Vendôme, Paris 1831.

NEVEUX, Anniversaire de la mort de Napoléon-le-Grand, détails intéressants sur la statue de l'empereur qui doit être placée sur la colonne de la place Vendôme, o. O. o. J. [Chant, par N.].

NIVE, Jean de la, Étienne Dolet. Soi-disant libre penseur, soi-disant brulé vif, auquel le Conseil Municipal de Paris élève une statue place Maubert aux frais des contribuables, Bourges 1889.

Note sur le Monument élevé à la mémoire du baron Larrey, Paris 1850.

Notice sur la Nouvelle statue équestre de Louis XIV, fondue d'après le modèle de M. Bosio, membre de l'Institut, Paris 1822.

[PARENT, Ulysse,] Rapport présenté au nom de la $5^{\mathrm{e}}$ Commission sur l'acquisition d'un groupe allégorique de Jules Dalou, dont l'esquisse a figuré à l'Exposition du concours pour l'érection d'une statue monumentale de la République, Paris 1880 (Conseil Municipal de Paris 1880).

PÉSSARD, Gustave, Statuomanie Parisienne. Étude critique sur l'abus des statues, Paris 1911.

Pétition contre l'érection d'une statue de Voltaire sur une place publique, o. O. 1869.

PICARD, Alfred, Exposition Universelle Internationale de 1889 à Paris, Bd. 2: Travaux de l'Exposition universelle, Paris 1891 (Ministère du Commerce, de l'Industrie et des Colonies).

POIRÉE, C., Une statue à Voltaire?, Garcin 1867.

POTTIER, Eugène, Le monument des Fédéres, Paris 1884.

[POUBELlE,] Condorcet. Inauguration de sa statue à Paris, Quai de Conti, le 14 juillet 1894.

Discours de M. P., Préfet de la Seine, Paris 1904. 
PRÉVLLLE, Louis de, À la Colonne, Bordeaux 1871.

Programme officiel du 15 août, Paris o. J.

Projet à son Excellence monsieur le comte de Persigny ministre de l'intérieur de l'agriculture et du commerce (signé: les membres du comité de la souscription nationale pour la statue équestre de Sa Majesté l'Empereur Napoléon III.), o. O. o. J.

Projet d'un monument à élever par souscription populaire à la mémoire des Fédérés de 1871 au Père-Lachaise sur l'emplacement concédé par le Conseil Municipal le 24 décembre 1883, Paris o. J.

Proposition d'ériger deux statues à la mémoire de Raspail, Paris o. J.

PUY D. J. du, Projet d'un Monument historique et symbolique à la gloire de la nation Française, exposé au Salon de 1849, Paris 1850.

14 Juillet 1878. Chant patriotique, paroles de Lefebvre, André, o. O. o. J.

QULLARD, Pierre, Le monument Henry. Listes des souscripteurs classées méthodiquement et selon l'ordre alphabéthique, Paris [16 oct.] 1899.

[RELDA, Suzanne,] Robespierre - mérite-t-il une statue? Conférence faite à la L.- Libre examen le 10 novembre 1908 par Mme S. R., publiciste. Éditée par le Comité du monument à Robespierre et à la Gloire de la Révolution, Paris 1908.

RENAN, Ernest, Qu'est-ce qu'une nation? Conférence faite en Sorbonne le 11 Mars 1882, Paris 1882.

[RENAUD, Armand,] Concours pour l'érection d'une statue à Condorcet. Rapport Général sur les opérations du jury, par A. R., rapporteur, Paris 1893 (Ville de Paris).

République Française. Grande fête nationale. Proclamation de la République aux pieds de la colonne de juillet. Revue de la Garde Nationale, o. O. o. J. [Montmirail 1848].

République Française. Liberté, Égalité, Fraternité: Inauguration du monument de Gamebtta, Paris o. J.

République Française, 1848. Char triomphal et funèbre qui a transporté, sous la Colonne de Juillet, les héros morts pour la patrie, Metz o. J.

ROUSSEL, François, Les monuments et la libre-pensée, Montpellier 1876.

ROZEN, Louis de, La Colonne, Paris 1874.

[SARDOU, V.,] Inauguration de la statue de Voltaire le mardi 14 juillet 1885. Discours de V. S. (directeur de l'Académie), Paris 1885 (Institut de France. Académie Française).

Scheurer-Kestner. La cérémonie du 11 février 1908. La statue du Luxembourg. Hommage du Journal d'Alsace-Lorraine à la mémoire de l'illustre compatriote, Strasbourg 1908.

SERY, Jean, Pour le mur des Fédérés, Paris 1907.

SILVSTRE, Armand, Le Monument de Gambetta, in: L'illustré Moderne 15 (14 juillet 1888) S. 3.

SiMON, Gustave, Charles SIMON (Hg.), Jules Simon, Figures et Croquis, Paris 1909.

[SIMON, Jules,] Inauguration de la statue de Jean-Jacques Rousseau à Paris le dimanche 3 février 1889. Discours de M. J. S., Paris 1889 (Institut de France. Académie Française).

SIRECH, abbé, Jeanne d'Arc et le patriotisme contemporain. Discours prononcé à Lyon, le 19 mai 1901 en l'Église Sainte-Blandine, Lyon 1901.

Société-médico-psychologique, séance du 25 mars 1878. Présidence de M. Baillarger. Une statue à Pinel. Rapport de la Commission composée de MM. les Drs. J. Falret, L. Lubier et Legrand du Saulle [rapporteur], Paris 1878.

Souscription pour l'érection d'une statue à la mémoire de Vauquelin, Paris 1865.

Souscription pour un monument à élever à la mémoire du Baron Larrey, Paris 1842.

Souscription Nationale. Monument à élever à la mémoire du Prince Eugène Beauharnais, $\mathrm{Pa}$ ris 1854 .

Souscription publique pour élever un monument à Claude Bernard, Paris 1878.

Souscription nationale 1870-1871. Programme, Paris (16 juin) 1871.

Souscription nationale pour le rétablissement de la statue de l'Empereur Napoléon $\mathrm{I}^{\text {er }}$ sur la Colonne Vendôme, Paris 1875. 
Souscription nationale destinée à ériger une statue à Jeanne d'Arc, Orléans 1848.

Souvenir de Gambetta dédié aux patriotes. Monument Gambetta commencé le 15 avril 1885 , place du Carrousel, inauguré le 13 juillet 1888 , Paris 1888.

[SPULLER, Eugène,] Inauguration du Monument de Gambetta. Discours de M. E. S., Président du Comité de souscription, Paris 1888.

La Statue de Henri IV. Nouveau Pont-Neuf. Sur le rétablissement et l'inauguration de la statue de Henri IV chanté et distribué le 15 août 1818 en l'honneur de la fête de S.M. Louis XVIII., o. O. o. J.

Statue de Jeanne d'Arc, o. O. (20 février) 1874.

La Statue de l'impératrice Joséphine suivie de sa biographie historique, o. O. [Paris] 1867.

Statue de Nicolas Leblanc, Inventeur du procédé de fabrication de la soude extraite du sel marin. Souscription internationale. Compte rendu de la cérémonie de l'inauguration du 28 juin 1887, Coulommiers 1887.

La Statue de Raspail. Son inauguation à Paris le 7 juillet 1889, Paris 1890.

La Statue de Voltaire. Paris o. J.

La Statue de Voltaire, érigée par lui-meme, Paris 1867.

Statues \& Gloires de la République, Paris 1888.

Les Statues de Napoléon I ${ }^{\text {er }}$, Paris 1863.

Statues de Voltaire et de Jean-Jacques Rousseau par un ami de la vérité à ses compatriotes de Meymac et Dussel, à ses amis de Tulle et de Limoges, Limoges 1871.

SULLY PROUDHOMME, Inauguration de la statue de Lamartine, le mercredi 7 juillet 1886. Discours de M. S. P., membre de l'Académie Française, Paris 1886 (Institut de France. Académie Française).

TÉNOT, Eugène, Paris en décembre. Étude historique sur le Coup d'État, Paris ${ }^{12} 1868$.

THEYRAS, G., Garibaldi en France 1870-1871, Paris ${ }^{2} 1891$.

THIOLLET, À MM. les députés de la commission du monument de Napoléon, Paris (26 mars) 1843.

THOMAS, Jules, Concours pour l'érection au rond-point de Courbevoie d'un monument allégorique de la Défense de Paris en 1870. Rapport présenté au nom du jury chargé du classement des esquisses, Paris 1879 (Publication de la Préfecture de la Seine).

-, Département de la Seine Concours pour l'érection au rond-point de Courbevoie d'un monument allégorique de La Défense de Paris en 1870. Rapport présenté au nom du Jury chargé de juger les modèles admis au second degré du concours, par M. J.T., Rapporteur, Paris 1880.

TOUQUET, (J.-B.-P.), Souscription pour l'érection d'un monument à la mémoire de Voltaire et de J.-J. Rousseau, Paris (3 janvier) 1822.

TOURNEFORT, Paul de, Au Sergent Bobillot. Poésie dite à Paris, le 4 avril 1886, à la matinée organisée au Théâtre des Folies-Bergère, par le comité de souscription au monument, Paris 1886.

Le Triomphe de la République. Fête d'inauguration de ce monument, érigé place de la Nation. Compte rendu officiel, Paris 1900 (Conseil Municipal de Paris).

TroISMONTS, Charles Piel de, Napoléon III et la nationalité Française. Quatrième mémoire aux hommes d'État d'Europe, Paris 1853.

VAUDREMER, Concours pour l'érection, place de la République, d'une statue monumentale de la République. Rapport présenté au nom du jury chargé du classement des esquisses, Paris 1879 (Ville de Paris).

VIGNOLS, Léon, Statues aux traitres et aux faussaires 1816-1820, 1889, Paris 1899.

VOGÚE, Eugène Melchior de, Remarques sur l'Exposition du centenaire, Paris 1899.

VORBE, Proposition relative à l'érection d'une statue à Galilée sur l'une des places de Paris et suivie d'un projet de fêtes internationales annuelles, Paris 1900.

Wallon, Henri, La démolition des ruines des Tuileries. Discours prononcé au Sénat dans la séance du mardi 27 juin 1882, Paris 1882. 


\subsection{Periodika}

L'Artiste, $1848 \mathrm{ff}$.

La Bataille, 1883-1914

Le Constitutionnel. Journal politique et littéraire, 1848-1914

La Croix, $1883 \mathrm{ff}$.

Le Gaulois, $1868 \mathrm{ff}$.

L'Illustration, Journal universel, $1843 \mathrm{ff}$.

Le Magasin pittoresque, $1848 \mathrm{ff}$.

Le Monde, 1860-1896

Le Moniteur Universel, $1848 \mathrm{ff}$.

Le Petit Journal, 1863 ff.

Le Rappel, $1869 \mathrm{ff}$.

La Revue des deux Mondes, 1848ff.

Le Siècle, $1848 \mathrm{ff}$.

Le Temps, Journal quotidien politique et littéraire, $1861 \mathrm{ff}$.

L'Union, 1847-1883

L'Univers, 1848 ff. (1860 fusioniert mit Le Monde, emeut ab 1867)

\section{Deutsche Quellen}

\subsection{Archivalien}

Geheimes Staatsarchiv Preußischer Kulturbesitz, Berlin/Dahlem

I. HA Rep. 89 Geheimes Zivilkabinett, jüngere Periode 1807-1920 (1924)

Nr. 20782 Denkmäler im Deutschen Reich, Bd. 1 (1846-1897).

Nr. 20791 Denkmäler im Allgemeinen 1889-1918.

Nr. 20835 Denkmäler in Berlin, Bd. 1 (1845-1873).

Nr. 20836 ibid. Bd. 2 (1847-1890).

Nr. 20837 ibid. Bd. 3 (1891-1899).

Nr. 20838 ibid. Bd. 4 (1900-1903)

Nr. 20839 ibid. Bd. 5 (1904-1909).

Nr. 20840 ibid. Bd. 6 (1910-1916).

Nr. 20886 Errichtung von Denkmälern für Reformatoren, Bd. 1 (1846-1882).

Nr. 20893 Monument für den Reformator der Landwirtschaftswissenschaft Albrecht Thaer 1840-1843.

Nr. 20894 Standbilder für den Oberlandes-Baudirektor Schinkel, den Wirkl. Geh. Rat Beuth und den Landwirtschaftswissenschaftler Albrecht Thaer in Berlin 1854

Nr. 208951885.

Nr. 20896 Schiller-, Goethe- und Lessing-Denkmal in Berlin 1859-1890.

Errichtung von Denkmälern für den Reichskanzler von Bismarck, Bd. 1 (1876-

Nr. 20897 1902).

Nr. 20903 ibid. Bd. 2 (1903-1915).

Errichtung von Denkmälern für Mitglieder der königlichen Familie, Bd. 1 (1823-1884).

Nr. 20907 ibid. Bd. 5 (1902-1906).

Nr. 20911 Monument für König Friedrich II. in Berlin 1829-1848.

Nr. 20914 Denkmäler für König Friedrich Wilhelm Ill., Bd. 1 (1841-1883).

Nr. 20915 ibid. Bd. 2 (1884-1916). 
Nr. 20916 Errichtung von Denkmälem für Friedrich Wilhelm III., für Freiherrn vom Stein und Staatskanzler Fürst Hardenberg, Bd. 1 (1858-1874).

Nr. 20917 ibid. Bd. 2 (1875-1907).

Nr. 20918 Denkmäler für Kaiser Wilhelm I., Bd. 1 (1862-März 1889).

Nr. 20923 ibid. Bd. 6 (1897).

Nr. 20933 Nationaldenkmal für Kaiser Wilhelm I. 1888-1902.

Nr. 20934 Denkmäler für Kaiser Friedrich III., Bd. 1 (1888-1896).

Nr. 20940 Denkmäler für Kaiser Wilhelm II. (1889-1918).

Nr. 20420 Bau der Nationalgalerie und die Herstellung eines Reiterstandbildes König Friedrich Wilhelms IV. auf ihrer Freitreppe (1861-1888).

Nr. 31799 Statuen im Tiergarten, Berlin, Bd. 1 (1821-1896).

Nr. 31803 ibid. Bd. 5 (1901-1902).

Nr. 31808 Statuen im Tiergarten, Berlin, Mappe 1 (1894-1899).

Nr. 32445 Nagelung hölzerner Bildwerke zu wohltätigen Kriegszwecken 1915-1917.

I. HA Rep. 151 I C Finanzministerium 1808-1945

Nr. 8270 Kosten für Errichtung und Unterhaltung öffentlicher Denkmäler und Bildwerke, Bd. 1 (1816-1853).

Nr. 8314 Die vom König Friedrich Wilhelm III. erlassene Kabinettsordre vom 26.3.1840 über die Grundsteinlegung zum Denkmal Friedrichs II. (1840).

Nr. 8315 Errichtung des Denkmals Friedrichs II. in Berlin (1840-1928).

Nr. 8316 Denkmal Friedrichs II. in Bromberg und Breslau, Friedrich Wilhelms II. in Königsberg, im Tiergarten bei Berlin, in Köln und in Breslau (1841-1908).

Nr. 8321 Errichtung eines Denkmals für Friedrich Wilhelm III., den Freiherrn vom Stein und den Fürsten Hardenberg in Berlin 1858-1878.

Nr. 8329 Errichtung eines Denkmals für Kaiser Wilhelm I. (1888-1894).

I. HA Rep. 151 IV

Nr. 2380 Errichtung und Erhaltung der Statuen und Monumente in Berlin durch den Staat, Bd. 3 (1863-1934).

I. HA Rep.77 Ministerium des Innern, Tit. 151 (Literatur und Denkmäler, 1. Reihe)

Nr. 15 Die Denkmäler in den preußischen Staaten, 19 Bände (1815-1931).

Nr. 15 Fasz. 19 Denkmal von Roon (1901-1904).

Nr. 15 Fasz. 49 Denkmal Eugen Richter in Berlin (1908-1909).

Nr. 15 Fasz. 51 Denkmal Rudolf Virchow in Berlin (1908-1910).

Nr. 15 Fasz. 55 Denkmal Königspaar Charlottenburger Brücke 1909.

Nr. 15 Fasz. 60 Denkmal Theodor Fontane - Tiergarten Berlin 1909-1910.

Nr. 81

Die Errichtung eines Denkmals für den Wirklichen Geh. Rat Beuth 18531854.

Nr. 106 Adh. 1 Nationaldenkmal für Kaiser Wilhelm I. auf der Schloßfreiheit in Berlin 1888-1902.

Nr. 106 Adh. 2 Denkmäler für Königin Luise, Kaiserin und Königin Augusta und Kaiserin und Königin Friedrich 1895-1913.

Nr. 106 Fasz. 55 Denkmal und Museum Friedrich III. in Berlin 1897-1904.

Nr. 108

Die Denkmäler für des Kaisers und Königs Wilhelm II. Majestät 18991914.

Nr. 108, Bei- Die Denkmäler für Ihre Majestät die Kaiserin und Königin Auguste Vikakten 1 toria 1909.

Nr. 109 Errichtung eines Portals zum Friedhofe der am 18. März 1848 in Berlin Gefallenen im Friedrichshain 1897-1899.

I. HA Rep. 77 Tit. 1215 (Literatur und Denkmäler, 2. Reihe)

Nr. 3a Beih. 1 Einrichtung eines Bismarck-National-Denkmals (2 Zeitungsauschnitte) 
I. HA Rep. 76 Kultusministerium 1807-1935. Ve Kunstsachen. Generalia, Sekt. I. Abt. 1 Die bildende Kunst

Nr. 5 Die Errichtung von Standbildern berühmter Männer, Bd. I (1897-1901).

Nr. 6 Die Herstellung von Statuen, Büsten und Gemälden fürstlicher Personen und berühmter Männer für öffentliche Anstalten, Bd. 1 (1848-1904).

I. HA Rep. 93 B Ministerium für öffentliche Arbeiten

Nr. 2350 Errichtung einer Bildsäule König Friedrichs II. in Berlin 1829-1892.

Nr. 2355 Errichtung eines öffentlichen Monuments für den Wirklichen Geh. Rat Beuth, für A. Thaer und Schinkel, Bd. 1 (1853-1862).

Nr. 2364 Bd. 2 (1862-1888).

Nr. 2365 Errichtung von Denkmälern in Berlin. Privat, Bd. 1 (1875-1901).

Nr. 2366 Bd. 2 (1901-1919).

Nr. 2369 Polizeiverordnung vom 10. März 1879 zum Schutz des Nationaldenkmals auf dem Kreuzberg, Bd. 1 (1878-1882).

Nr. 2370 Bd. 2 (1882-1906).

Nr. 2371 Errichtung eines Lutherdenkmals in Berlin 1884-1894.

Nr. 2373 Errichtung eines Nationaldenkmals für Kaiser Wilhelm in Berlin, Bd. 1 (18881893).

Nr. 2374 Bd. 2 (1894-1902).

Nr. 2375 Bd. 3 (1902-1919).

Nr. 2376 Errichtung eines Denkmals für Kaiser Friedrich in Berlin 1889-1903.

Nr. 2377 Errichtung eines Denkmals für die Kaiserin Augusta auf dem Opernplatz in Berlin 1895.

Nr. 2378 Nationaldenkmal für den Fürsten Bismarck in Berlin 1898.

Nr. 2379 Denkmal für den Staatskanzler Fürsten von Hardenberg in Berlin 1904-1907.

Nr. 2342 Ehrung gefallener Krieger durch Denkmäler, Heldenhaine, etc. (1915-1917).

I. HA Rep. 169 C Abgeordnetenhaus 1849-1913. Abschnitt 15 Denkmäler

Nr. 1 Errichtung von Denkmälern und Konservierung von Alterthümern, 3 Bände (18591913).

Nr. 4 Das Nationaldenkmal für Kaiser Wilhelm I. (1888-1901).

I. HA Rep. 169 B Parlamentarische Körperschaften der Jahre 1847/48

Nr. 4 Akten des Preußischen Nationalversammlung von 1848.

Nr. 10 Antrag [...] der invaliden Kämpfer sowie Errichtung eines Denkmals für die Gebliebenen.

Landesarchiv Berlin

A Rep. 000-02-01 Stadtverordnetenversammlung von Berlin 1809-1945. [Sektion I. Allg. Verwaltungsfragen. I.7 Denkmäler]

Nr. 1620 Die Feier des 100jährigen Geburtstages Alexanders von Humboldt bzw. die Errichtung eines Nationaldenkmals 1869.

Nr. 1621 Die Feier des 100jährigen Geburtstages Friedrich von Schillers und die Errichtung eines Schillerdenkmals, Bd. 1 (1859-1874).

Nr. 1622 Das Schillerdenkmal, das Goethedenkmal, und das Lessingdenkmal, Feier des 100jährigen Todestages Schillers, Bd. 2 (1875-1906).

Nr. 1627 Die Denkmäler der Kaiser Wilhelm I. und Friedrichs III. 1888-1905.

Nr. 1631 Die Errichtung eines Denkmals des Kaisers und der Kaiserin Augusta 1890-1893.

Nr. 1632 Das Hegel-Denkmal auf dem Bauhof 1870-1875.

Nr. 1633 Die Errichtung eines Denkmals für den Staatsminister Freiherm vom Stein und das Denkmal des Staatskanzlers Fürsten von Hardenberg auf dem Dönhoffplatz 1860-1914.

Nr. 1634 Die Errichtung von Denkmälem. Darin: Lagepläne. Bd. 1 (1859-1891). 
Nr. 1635 Bd. 2 (1892-1903).

Nr. 1636 Bd. 3 (1904-1920).

Nr. 1637 Die Sammlungen zur Errichtung eines Denkmals des Kaisers und der Kaiserin Augusta 1891-1892.

Nr. 1638 Die Finanzlage bei der Errichtung eines Denkmals des Kaisers und der Königin Augusta 1891-1895.

Nr. 2381 Das Denkmal des Königs Friedrich Wilhelm III. im Tiergarten, desgleichen der Königin Louise. Das Denkmal des Kaisers und der Kaiserin Augusta auf dem Opernplatz 1849-1895.

A Rep. 001-02 Magistrat der Stadt Berlin. Generalbüro

Nr. 261 Denkmäler Nr. 2. Errichtung von Standbildern der Dichter Lessing, Goethe und -264 Schiller.

Nr. 265 Denkmäler Nr. 191. Preisausschreiben zur Errichtung eines Lutherdenkmals, Bd. 1 (1885).

Nr. 266 Denkmäler Nr. 192. Verträge über die Errichtung eines Lutherdenkmals, Bd. 2 (1886).

Nr. 267 Denkmäler Nr. 193. Errichtung und Einweihung des Lutherdenkmals, Bd. 3 (1892-1896).

Nr. 268 Denkmäler, spez.Verwaltungsstreitsache des Magistrats gegen den Präsidenten wegen des Friedhofs der Märzgefallenen im Friedrichshain. 1899-1900.

Nr. 269 Denkmäler, spez. Antrag auf Errichtung eines Denkmals für die Märzgefallenen. 1897-1911.

Nr. 3274 Denkmäler Nr. 10. Errichtung eines Denkmals in Berlin für Dr. Martin Luther. 1883-1895.

Brandenburgisches Landeshauptarchiv, Potsdam

Rep. 2A Regierung Potsdam I P

Nr. 718 Geldsammlungen zum Bau eines Schinkeldenkmals in Berlin, 1858-1861.

Nr. 719 Geldsammlungen zur beabsichtigten Errichtung eines Denkmals für den Freiherm vom Stein, 1860-1861.

Nr. 720 Subskriptionssammlungen zur Errichtung öffentlicher Denkmäler, Bd. 2, 18701892.

Nr. 723 Kaiser-Wilhelm-Denkmal in Westend-Charlottenburg, 1888-1891.

Rep. 2A Regierung Potsdam I Hb

Nr. 1233 Errichtung eines Denkmals für Albrecht Thaer in Berlin sowie für den Wirklichen Geheimen Rat Beuth, 1843-1854.

Nr. 1235 National-Kriegerdenkmal im Park des Invalidenhauses in Berlin, 1850-1871.

Nr. 1236 Denkmale für König Friedrich II. in Berlin und für König Friedrich Wilhelm III., 1851-1897.

Rep. 30 C Polizeipräsidium Berlin

Nr. 2917 Der Aufruf zu Beiträgen für Errichtung eines Denkmals zum Andenken der am 18./19.März gefallenen Soldaten. 1849

Rep. 30 C Tit. 94 Polizeipräsidium Berlin

Nr. 9795 Ehrung der Märzgefallenen in Friedrichshain in Berlin, Bd. 1 (1850-1891).

Nr. 9796 Bd. 2 (1892-1897).

Nr. 9797 Bd. 3 (1898-1899).

Nr. 9798 Bd. 4 (1900-1902).

Nr. 9799 Bd. 5 (1903-1906).

Nr. 9800 Bd. 6 (1907-1909).

Nr. 9801 Bd. 7 (1910). 
Nr. 9821 Die beabsichtigte Errichtung eines Denkmals für die Märzgefallenen im Friedrichshain in Berlin und die dafür veranstalteten Geldsammlungen, Bd. 1 (18521898),

Nr. 9822 Bd. 2 (1989-1900).

Bundesarchiv Berlin. Abteilung Reich

R 1501 Reichsministerium des Innern

Nr. 115007 Nr. 34 Errichtung eines Denkmals für Kaiser Friedrich III. August, 1889Dezember 1889.

Nr. 115040 Nr. 69 Denkmal für Kaiser Wilhelm I., Oktober 1888-September 1892.

R 43 Alte Reichskanzlei [Bestandsnummern der Microfiches]

Nr. 2388 Akten betreffend Denkmäler, Bd. 1: 17. September 1900-24. Dezember 1904.

Nr. 2389 Akten betreffend Denkmäler, Bd. 2: 19. Februar 1905-20. November 1908.

Nr. 2390 Akten betreffend Denkmäler, Bd. 3: 4. Juni 1908-31. Januar 1910.

Nr. 2393 Akten betreffend Denkmäler, Bd. 6: 11. Januar 1912-23. Januar 1913.

\subsection{Gedruckte Quellen}

ABSHOFF, Fritz, Deutschlands Ruhm und Stolz. Unsere hervorragendsten Denkmäler in Wort und Bild, Berlin 1904.

Zwei Actenstücke betreffend die Errichtung eines Denkmals für Goethe in Berlin nebst unmassgeblichen Vorschlägen für die Vertheilung der einzelnen Mitglieder des Comités in vier Abtheilungen und einen leitenden Ausschuss, Berlin 1860.

ALBRECHT, Gustav, Die Denkmäler in der Siegesallee zu Berlin in ihrer Bedeutung für die vaterländische Geschichte, 2 Hefte, Berlin 1898.

Album, gewidmet den in den Jahren 1848 und 1849 treu ihrer Pflicht für König und Vaterland gefallenen Söhnen des Preußischen Heeres, bei Gelegenheit der Grundsteinlegung der diesen Treuen geweihten Denksäule im Königlichen Invaliden-Park zu Berlin am 18. Juni 1850, o. O. o. J.

Ausfuehrliche Erklaerungen der vier Reliefs sowie des grossen (Anton v.) Wernerschen Rundgemaeldes an dem Siegerdenkmal auf dem Königsplatze zu Berlin, Berlin 1874.

BECHDOLT, Zur Kaiser-Denkmalfrage in Berlin, o. O. o. J. [gedruckt in: GStA PK I.HA Rep. 77 Tit. 151 Nr. 106 Adh.1]

Zur Begründung des in der Sitzung des Goethecomités am 7. April 1862 von Hotho, v. d. Hude und H. Grimm eingebrachten Antrags, Berlin 1862.

Das Bismarckdenkmal vor dem Reichstagsgebäude, Berlin o. J.

Zum Bismarckdenkmal vor dem Reichstagsgebäude, Berlin 1901.

BLANKENSTEN, H., Über die Ergebnisse der Wettbewerbung zum National-Denkmal für Kaiser Wilhelm. Vortrag gehalten im Architektenverein zu Berlin am 14. Oktober 1889, Berlin 1889.

BOERNE, Ludwig, Die Vendôme-Säule 1822/24, in: Sämtliche Schriften, Bd. 2, Düsseldorf 1964, S. 102.

BOIS-REYMOND, Emil du, Die Humboldt-Denkmäler von der Berliner Universität. Zur Feier des Geburtstages Friedrich Wilhelm's III. in der Aula der Königlichen Friedrich-WilhelmsUniversität zu Berlin am 3. August 1883 gehaltene Rede, in: DERS., Friedrich II. in englischen Urtheilen. Darwin und Kopernikus. Die Humboldt-Denkmäler ..., Leipzig 1884. S. 59-120.

BRAHM, Otto, Goethe und Berlin. Festschrift zur Enthuellung des Berliner Denkmals, Berlin 1880. 
BRANDIS, C.G., Ferdinand KoHLHEIM (Hg.), Das Denkmal Friedrichs des Großen in Berlin. Beschrieben und mit Gedichten aus älterer und neuerer Zeit versehen v. F. KOHLHEIM, Berlin 1871.

BRAB, August, Berlin's Barrikaden. Ihre Entstehung, ihre Vertheidigung und ihre Folgen. Eine Geschichte der Märzrevolution, Berlin 1848.

BUCHNER, Wilhelm, Deutsche Ehrenhalle. Die großen Männer des deutschen Volkes in ihren Denkmälern, Darmstadt 1862.

Denkmal König Friedrichs des Großen, enthüllt am 31. Mai 1851, Berlin 1851.

Das Drei-Statuen-Projekt. Als Ms gedruckt, Berlin 1862.

Deutschlands Siegessäule auf dem Königsplatze in Berlin zum Gedächtnis der Kriegsjahre 1864, 1866, 1870-71, Berlin o. J.

EHRHARD, Max, Bismarck im Denkmal des In- und Auslandes, Eisenach-Leipzig 1903

Die Enthuellung des Emil-Fischer-Denkmals zu Berlin, 25. Nov. 1921 (Zeitschrift fuer angewandte Chemie Jg. 34, Nr. 104), Berlin 1921.

Entwuerfe zu dem Denkmal fuer Seine Durchlaucht den Fuersten Bismarck in der Reichshauptstadt, Berlin 1895 (Sammelmappe hervorragender Concurrenz-Entwuerfe Heft XXXI).

Da ist Er! Zum Gruße Berlin's an des großen Königs Standbild am 31. Mai 1851 und Erläuterung der Bildwerke an dem Denkmal, Berlin 1851.

Zur Erinnerung an die Enthüllung des Goethe-Denkmals in Berlin, am 2. Juni 1880, Berlin 1880

Zur Erinnerung des Denkmals Friedrichs II., 31. Mai 1851, Berlin 1851 [Berlinische Nachrichten von Staats- und gelehrten Sachen $N^{\circ} 125$ ].

EULER, Carl, Das Jahndenkmal in der Hasenhaide bei Berlin. Eine ausführliche Darstellung seiner Geschichte und Beschreibung der bei seiner Enthüllung am 10. und 11. August 1872 veranstalteten Festlichkeiten. Beilage zur Deutschen Turnzeitung 1873-1874, Leipzig 1874.

FOERSTER, Wilhelm Julius, Alexander von Humboldt. Eine Gedächtnisrede zur Feier der Denkmalsenthüllung am 28. Mai 1883 gehalten, Berlin 1883

FONTANE, Theodor, Denkmal Albrecht Thaers zu Berlin. Nach dem Entwurfe von Christian Rauch ausgefuihrt von $\mathrm{H}$. Hagen, Berlin 1862.

[Friedrich Wilhelm IV.,] Zwei Reden des Königs Friedrich Wilhelm IV. Vom Throne gesprochen am 15. Oktober 1840 bei der Huldigung in Berlin, Berlin 1840.

Die Friedrichs-Feier in Berlin am 31. Mai 1851. Ein Gedenkbuch für alle Preußen, Berlin 1851.

Führer durch die Ruhmeshalle und die Königlichen Sammlungen, Berlin 1900.

GARLEPP, Bruno (Hg.), Bismarck-Denkmal für das deutsche Volk. Jubiläumsausgabe zum 100. Geburtstage des großen Kanzlers 1815-1915, Berlin 1915.

Das Goethe-Denkmal im Thiergarten zu Berlin, Berlin 1880.

GRIMM, Hermann, Die Standbilder Alexanders und Wilhelms von Humboldt vor der K. Universität zu Berlin, in: Preußische Jahrbücher 51 (1883) S. 641-650.

Gutachten der Kunstabtheilung des Goethe-Comité über die Aufstellung der drei Standbilder von Schiller, Goethe und Lessing auf dem Gensdarmenmarkte in Berlin, Berlin 1862.

HAGEN, August, Ueber Reiterstatuen, Königsberg 1844.

D'HARgues, Eugène, Rede zur Einweihung und Enthüllung des Calvin-Denkmals am 28. Oktober 1885, Berlin o. J.

Hegels Säcularfeier, in: Der Gedanke. Zeitschrift für wissenschaftliche Forschung und Kritik. Organ der Philosophischen Gesellschaft zu Berlin 8 (1871) S. 122-165.

HOFFMEISTER, Hermann (Hg.), Neuestes PreuBisches Helden-Denkmal. Ein poetisches Gedenkbuch zur Feier der Großthaten des Jahres 1866 für das Preußische Volk und Militär, ein Deklamations- und Prämienbuch für Schulen, Berlin 1867. 
-, Das National-Siegesdenkmal der Deutschen Kaiserstadt ... Ein Gedenkbuch für das deutsche Volk, Berlin o. J. [1874].

HOLZAMER, Wilhelm, Die Siegesallee. Kunstbriefe an den deutschen Michel, Leipzig 1902.

HOSSFELD, Die Preisbewerbung um das National-Denkmal für Kaiser Wilhelm I. in Berlin, Berlin 1889.

KAISER, Hermann, G.W.F. MULLER, Vorschlag zur Errichtung einer Reihe von Denkmälem berühmter deutscher Männer Unter den Linden in Berlin, Berlin 1859.

[KNOPF, A. E.,] Das Goethe-Denkmal im Thiergarten zu Berlin. Enthüllt am 2. Juni 1880, Berlin 1880.

KOHLHEIM, F., Das Denkmal Friedrichs des Großen in Berlin. Beschrieben und mit Gedichten aus älterer und neuerer Zeit versehen, Berlin 1851.

KOPISCH, August, Beschreibung und Erklärung des Denkmals Friedrichs des Zweiten in Berlin, Berlin 1851.

Der Kranz für die Märzgefallenen. Aktenstücke zur Geschichte der Selbstverwaltung und der öffentlichen Meinung der Preussen, Berlin 1898.

KRIEGER, Heinz, Die Kämpfe um ein Märzdenkmal 1848-1898. Ein Beitrag zur Kulturgeschichte. Im Auftrage des Denkmalcomités von 1896, Berlin 1899.

Die Krone und die Reichshauptstadt. Allgemeinpolitische Betrachtungen und Erörterungen der Konflikte zwischen der Krone und der Stadt Berlin. Von einem Berliner, Berlin 1902.

KUNEL, Christian Klaus, Warum ist Schiller der Dichter der Nation? Nürnberg 1859

KuNTZEMƯller, Otto, Die Denkmäler Kaiser Wilhelms des Großen in Abbildungen mit erläuterndem Text, Bremen 1902.

LABAN, Ferdinand, Die Reiterdenkmäler Berlins und Wiens, Berlin 1908.

[Lessing-Comité,] Aktenstücke und Beläge, die am 6. November 1861 Allerhöchst genehmigte Vereinigung der Standbilder Lessing's, Schiller's und Goethe's vor dem Königlichen Schauspielhause zu Berlin betreffend (Vom Anfange 1861 bis 12. November 1867). Im Auftrage des Lessing-Comité hg. v. dessen Ausschuß, Berlin ${ }^{2} 1870$.

Lieder zur Nachfeier der Enthüllung des Friedrich-Monuments, gesungen am 6. Juni 1851.

LINDENBERG, Paul (Hg.), Hindenburg-Denkmal für das Deutsche Volk, eine Ehrengabe zum 80. Geburtstage des Reichspräsidenten, Berlin 1928.

MACKOWSKY, Hans, Die vorbereitenden Entwürfe Schinkels und Rauchs zum Denkmale Friedrichs des Großen in Berlin, Inaugural-Diss., Berlin 1894.

- Das Friedrichsdenkmal nach den Entwürfen Schinckels und Rauchs (1822-1836), Berlin 1894.

MAERTENS, Herrmann, Die deutschen Bildsäulen-Denkmale des XIX. Jahrhunderts. Nebst einer Abhandlung über die Grössenverhältnisse, die Materialauswahl, die Gruppierung, die Aufstellungsweise und die Kosten derartiger Monumente, Stuttgart 1892.

Die von Seiner Majestät dem Kaiser Wilhelm II. gestifteten Denkmäler in der Sieges-Allee zu Berlin, Berlin 1900.

MERCKLE, Kurt, Das Denkmal König Friedrichs des Großen in Berlin: Aktenmäßige Geschichte und Beschreibung des Monuments, Berlin 1891.

Die Modelle zum Schiller-Denkmal in Berlin. Ausgestellt im Concert-Saale des Königlichen Schauspielhauses im Juli und August 1862, Berlin 1862.

MƯLlER-BOHN, Hermann, Die Denkmäler Berlins. Ihre Geschichte und Bedeutung. Mit einem Anhang enthaltend Gedenktafeln und Wohnstätten berühmter Männer. Ein kunstgeschichtlicher Führer, Berlin 1905.

Das National-Denkmal $১$ Kaiser Wilhelm des Großen`. Nach Original-Aufnahmen, 0. O. o. J.

Das National-Denkmal auf dem Kreuzberge bei Berlin. Mit dem vom Denkmal aus sichtbaren Panorama von Berlin, Berlin 1901.

NAUMANN, Emil, Deutschlands musikalische Helden in ihrer Rückwirkung auf die Nation. Vortrag, gehalten am 15. Februar 1873 im Wissenschaftlichen Verein zu Berlin, Berlin 1873. 
OLFERS, J. F. v., Die Marmor-Gruppen auf der Schloßbrücke in Berlin, Berlin 1857.

PIPER, Ferdinand, Goethe's nationale Stellung und die Errichtung seiner Statue in Berlin, Berlin 1860.

PUTZ, Herrmann, Gedächtnisrede bei Enthüllung des Gerlach-Denkmales, gehalten am 30. Juli 1890 im Vorgarten der Königl. Thierärtzl. Hochschule zu Berlin, Berlin 1890.

QUIEN, Louis, Empfindungen bei der feierlichen Enthüllung des Denkmals Friedrichs des Grossen. Den Manen des grossen Königs dargebracht, Berlin am 31. Mai 1851.

RAHN, G., Das National-Kriegerdenkmal im Invalidenpark in Berlin. Ein Beitrag zur SpecialGeschichte Berlins, Berlin 1854.

RENISCH, Überblick über die Geschichte des Vereins >Bismarck-Warte' während seines fünfährigen Bestehens 1899-1904, mit besonderer Berücksichtigung der Grundsteinlegung und der Einweihung der Bismarck-Warte auf den Müggelbergen, Coepenick 1904.

RICHTER, Eugen, Schulze-Delitsch. Ein Lebensbild, zur Denkmalsenthüllung verfaßt, Berlin 1899.

ROBOLSKY, Hermann, Bismarck und die deutsche Nation, Leipzig 1890.

VON ROCHOW, Anordnung der Feierlichkeiten bei der Grundsteinlegung des auf Allerhöchsten Befehl zum Andenken des Regierungs-Antritts Sr. Hochseligen Majestät Königs Friedrich's II. zu errichtenden Denkmals, Berlin 1840.

SCHASLER, Max, Ueber die kuenstlerische Form der Denkmaeler Grosser Maenner, Berlin 1876 (Verhandlungen der philosophischen Gesellschaft zu Beriin, 4).

-, Ueber moderne Denkmalswuth, Berlin 1878 (Deutsche Zeit- und Streitfragen, Bd. 7).

Schiller-Denkmal Berlin 1871, Bd. 1, Berlin 1871.

Schiller-Denkmal. Festausgabe, 2 Bände, Berlin 1860.

SCHNABEL, Franz, Die Denkmalskunst und der Geist des 19. Jahrhunderts (1939), in: DERS., Abhandlungen und Vorträge 1914-1965, hg.v. Heinrich LUTZ, Freiburg, Basel, Wien 1970, S. 134-150.

[SCHNEDER,] Die Denksäule im Invaliden-Park zu Berlin, in: Der Soldatenfreund 22, Heft 6 (1854) S. 3-107.

SCHRADER, Clementine, Am Denkmal Friedrichs des Großen, Berlin 1851.

[SCHULZE, Adolf,] Festzeitung zur Feier der Enthuellung des Goethe-Denkmals im Thiergarten zu Berlin am 2. Juni 1880, Berlin 1880.

-, Die Denkmäler des Freiherm von Humboldt im Vorgarten der Kgl. Universität, Berlin 1883.

-, Deutschlands Siegessäule auf dem Königsplatze in Berlin zum Gedächtnis der Kriegsjahre 1864, 1866, 1870-1871, Berlin o. J.

[-,] Professor Rudolf Siemering's A.von Gräfe-Denkmal in Berlin. Enthüllt am 22. Mai 1882 , Berlin 1882.

SCHULTZE, Ernst, Wie wir unsere großen Dichter ehren sollten. Ein Wort über DichterDenkmäler und anderes, Leipzig 1902.

SEDEL, Paul, Der Kaiser und die Kunst, Berlin 1907.

Das Siegesdenkmal auf dem Königsplatze in Berlin mit der Inschrift: Das Dankbare Vaterland Dem Siegreichen Heere. Berlin, o. J.

SER, Richard, Deutschlands Geistes-Helden. Ehren-Denkmäler unserer hervorragenden Führer auf geistigem Gebiet in Wort und Bild. Auf Grund geschichtlicher Unterlagen und authentischer Quellen, Berlin 1904.

SOMMER, Andreas, Gedenkbuch, enthaltend die Geschichte und Beschreibung des FriedrichDenkmals in Berlin, sowie die Darstellung der Grundsteinlegung am 1. Juni 1840 und der Enthüllung desselben am 31. Mai 1851, hrsg. v. dem Comité der Veteranen in Berlin, Ber$\operatorname{lin}^{2} 1852$.

SPRINGER, Robert, Berlin - die deutsche Kaiserstadt, nebst Potsdam und Charlottenburg mit ihren schönsten Bauwerken und hervorragenden Monumenten, 1876, ND Leipzig 1988. 
Die Stellung der deutschen Nation zum Freiherm vom Stein, oder: Jetzt ist es doch wohl Zeit, daB Deutschland auch dem Freiherrn vom Stein ein Monument errichtet. Ein Anruf an die deutsche Nation. Der Ertrag zum Besten des Stein-Denkmals, Weimar 1860.

Stenographische Berichte über die Verhandlungen und den amtlichen Drucksachen des konstituierenden Reichstages des Norddeutschen Bundes, des Deutschen Zollparlaments und des Deutschen Reichstages vom Jahre $1867 \mathrm{ff}$., Berlin $1868 \mathrm{ff}$.

STERNFELD, Richard, Die Siegesallee. Amtlicher Führer durch die Standbildergruppen, Berlin 1900

SYDOW, Adolf, Worte bei der Grundsteinlegung zu Schillers Nationaldenkmal, am 10. November 1859 gesprochen, Berlin 1859.

TREITSCHKE, Heinrich von, Königin Luise. Vortrag, gehalten am 10. März 1876 im Kaisersaale des Berliner Rathauses, in: Preußische Jahrbücher 37 (1876) S. 417-429, und wieder in: DERS., Historische und politische Aufsätze, Bd. 4: Biographische und historische Abhandlungen, Leipzig 1897, S. 310-324.

-, Luther und die Deutsche Nation. Vortrag, gehalten in Darmstadt am 7. November 1883, in: ibid. 377-396.

TRENDELENBURG, A., Ansprache (über die Denkmäler der Königin Luise und der Freiheitskriege in Berlin), Berlin 1914 (Beilage zum Jahresbericht des Friedrich-Gymnasiums Ostern 1914. Die Feier des 10. März).

Zum Verständnis des Denkmals Kaiser Wilhelms I., Berlin o. J. [1901].

VOB, Georg, Die Entscheidung über die Entwürfe zum Nationaldenkmal für Kaiser Wilhelm. Dem Deutschen Reichstage als Denkschrift überreicht, Berlin ${ }^{2} 1889$.

WASSERMANN, W., Die Enthüllung des Sieges-Denkmals zu Berlin am 2. September 1873 Vollständige Darstellung der Geschichte und Ausführung des Denkmals, seiner Reliefs u. Gemälde, sowie der Enthüllungs-Feierlichkeiten, Berlin ${ }^{5} 1873$.

-, Den Manen Schillers. Des Dichters Leben, seine letzte Ruhestätte und Denkmäler im deutschen Sprachgebiete, Halle a.d.S. 1905.

ZUR WESTEN, Walter von, Zur Enthüllung des Rauchschen Friedrichsdenkmals in Berlin. Fest- und Erinnerungsblätter aus Anlaß der 75. Wiederkehr des Enthüllungstages zusammengestellt, Berlin 1926.

WOLFF, Albert, Berliner Revolutionschronik. Darstellung der Berliner Bewegungen im Jahre 1848 nach politischen, socialen und literarischen Beziehungen, 3 Bände, Berlin 1854.

-, Die Denkmale Berlins. König Friedrich Wilhelm III. Reiterstandbild Friedrich des Großen. Reiterstandbild des großen Kurfürsten. Standbild Blüchers. Steindenkmal. Kriegerdenkmal vor dem Landsberger Thor. Standbild Friedrich III. Im Thiergarten. Friedenssäule auf dem Belle-Alliance-Platz. Siegessäule, Berlin 1876.

\subsection{Periodika}

Berliner Tageszeitung

Die Dioskuren, 1856-1875

Die Gartenlaube, 1861-1918

Germania, Zeitung für das deutsche Volk, $1870 \mathrm{ff}$.

Illustrirte Zeitung, Leipzig, $1848 \mathrm{ff}$.

Kunst für Alle, 1885/86 ff.

Kunstchronik, Wochenschrift für Kunst und Kunstgewerbe, Leipzig, 1866 ff.

National-Zeitung, $1848 \mathrm{ff}$.

Neue Preußische [Kreuz]Zeitung, $1848 \mathrm{ff}$.

Norddeutsche Allgemeine Zeitung, 1861-1918

Der Neue Socialdemokrat, 1871-1875 (danach fusioniert mit dem Vorwärts)

Die Neue Zeit, 1883 ff.

Preußische Jahrbücher, 1858 ff. 
Vossische Zeitung (bis 1911: Koeniglich-Privilegirte Berlinische Zeitung von Staats- und gelehrten Sachen), $1848 \mathrm{ff}$.

Vorwärts [Centralorgan der Sozialdemokratie Deutschlands], Leipzig $1876 \mathrm{ff}$., ab 1891 Berlin

Die Zukunft, $1892 \mathrm{ff}$.

\section{Englische Quellen}

\subsection{Archivalien}

Public Record Office, Kew/London

Work 6 Miscellanea, 1609-1956

Work 6/119 Nelson Memorial Committee. 1838-1844.

Work 6/134/1 Special services. Wellington Monument.

Work 6/134/2 Parliamentary papers. 1858-1873.

Work 6/134/3 Press cuttings. 1903-1907.

Work 11 Office of Works and successors: Houses of Parliament: Correspondence and Papers, 1709-1973

Work 11/53 Houses of Parliament. Canning Statue Enclosure.

Work 11/59 Houses of Parliament: Sites for Statues in the vicinity of the Houses of Parliament, proceedings of Committee 1871.

Work 16 Royal Parks and Gardens, 1736-1989

Work 16/325 St. James's Park. The Mall Improvement (Approach). 1910-1913. Admirality Arch and Charing Cross.

Work 16/362 Hyde Park and Kensington Gardens. Prince Consort (Albert) Memorial. 18631872.

Work 20 Statues and Memorials, 1810-1985

Work 20/2/2 Nelson Column. 1839-1857. Construction, etc. of the Column (...)

Work 20/3/1 Nelson Column. 1845-1861. Construction and fixing of the Bas Relief in the panels of the pedestal of the Column.

Work 20/3/2 Nelson Column. 1845-1884. Modelling, casting and fixing of the Lions at the Base of the Column.

Work 20/4/2 Duke of Wellington Statue. 1828-1851. Erection of the equestrian statue on the summit of the Triumphal Arch in Constitution Hill.

Work 20/4/3 Duke of Wellington Statue. 1882-1885. Removal of statue from summit of Arch in Constitution Hill to Aldershot.

Work 20/10 King Charles I. 1810-1913. Suggested removal due to street widening.

Work 20/11 King Charles I. 1892-1912. Applications to decorate.

Work 20/12 Albert Memorial. 1872-1913. Transfer to O. W., Policing and watching arrangements.

Work 20/13 Albert Memorial. 1873-1913. Preservation and repairs.

Work 20/14 Albert Memorial. 1901-1904. Restauration of mosaics.

Work 20/15 Nelson's Column. 1874-1913. Repairs, cleaning and Verticality tests.

Work 20/16 Nelson's Column. 1887-1912. Damage to Plinth and Lions. Erection of platforms for public speaking.

Work 20/19 Queen Victoria Memorial. 1901-1912. Sir Thomas Bock's Studio.

Work 20/20 Queen Victoria Memorial. 1902-1914. Erection.

Work 20/21 Queen Victoria Memorial. 1903-1913. Transfer to Board.

Work 20/24 Queen Victoria Memorial. 1904-1906. Representation of Dominions and Colonies. 
Work 20/25 Queen Victoria Memorial. 1911-1911. Arrangements for unveiling ceremony.

Work 20/28 Richard Coeur de Lion. 1850-1895.

Work 20/29 Sir James McGrigor. 1850-1909.

Work 20/31 Sir Robert Peel. 1853-1877.

Work 20/32 Sir Charles Napier. 1854-1858.

Work 20/33 Edward Jenner. 1857-1897.

Work 20/34 General Sir Henry Havelock. 1858-1907.

Work 20/36 Lord Herbert of Lea. 1862-1906.

Work 20/38 Lord Clyde. 1864-1903.

Work 20/40 Lord Palmerston. 1866-1877.

Work 20/42 Earl of Derby. 1870-1879.

Work 20/44 Sir J. Burgoyne. 1873-1902.

Work 20/46 King Charles II. 1877-1910.

Work 20/47 Lord Byron. 1880-1904.

Work 20/48 Earl of Baconsfield. 1881-1889.

Work 20/49 Duke of Wellington. 1884-1891.

Work 20/50 General Gordon. 1885-1907.

Work 20/56 Sir John Millais. 1904-1906.

Work 20/58 Duke of Cambridge. 1905-1907.

Work 20/60 King William III. 1906-1908.

Work 20/61 Lord Clive. 1908-1912.

Work 20/62 Duke of Devonshire. 1908-1911.

Work 20/63 King Edward VII. 1910-1914.

Work 20/64 King William III. 1910-1917.

Work 20/67 Florence Nightingale. 1911-1912.

Work 20/76 Lord Strathnaim. 1891-1897.

Work 20/77 Queen Victoria. 1893-1909. Kensington Gardens.

Work 20/79 Captain Cook. 1911-1915.

Work 20/80 Report by Sir Frank Baines, 1914. 1914-1915. Conditions and maintenance of statues and memorials in general.

Work 20/83 Rt. Hon. William Huskisson. 1915. Pimlico Garden facing Grosvenor Road.

Work 20/85 Sir John Franklin. Trafalgar Square. 1861-1914.

Work 20/93 Duke of Kent. 1897-1912.

Work 20/94 Lord Lawrence. 1900-1901.

Work 20/97 Lord Napier of Magdala. 1890-1913.

Work 20/99 Queen Anne Statue. 1861-1909. Queen Square, now Queen Anne's Gate, Westminster.

Work 20/100 Oliver Cromwell, Houses of Parliament. 1894-1910.

Work 20/103 Florence Nightingale. 1913-1925.

Work 20/104 Queen Victoria Memorial: Transfer to Board and Funds. 1914-1919.

Work 20/107 Lord Clive, King Charles Street. 1916-1920.

Work 20/110 Trafalgar Square. 1886-1916. Regulations concerning meetings and exhibitions (1892), and revised regulations (1914). With solicitors advice.

Work 20/114 Queen Anne Statue. 1937-1939. Queen Square (now Queen Anne's Gate, Westminster.

Work 20/1 15 Oliver Cromwell. 1937-1947. Houses of Parliament.

Work 20/125 Albert Memorial, Kensington Gardens: preservation and repairs. 1914-1939.

Work 20/126 King Charles I, Charing Cross: maintenance etc.

Work 20/127 Capt. R.F. Scott, C.V.O., R.N., Waterloo Place. 1914-1943.

Work 20/128 Nurse Cavell Memorial, St. Martin's Place. 1915-1935.

Work 20/135 Lord Napier of Magdala, Queens Gate SW 7, formerly in Waterloo Place.

Work 20/223 Scope of Metropolitan Statues Act. 1854-1931. 
Work 20/224 Queen Victoria Memorial: 1. Arrangement for protection. 2. Opening to the public. 1909-1951.

Work 20/225 Choice of sites: policy. 1912-1938

Work 20/228 1. Policy. 2. List of statues scheduled under the Public Statues (Metropolis) Act 1854. 1921-1926.

Work 20/253 Historical notes on statues not in charge of Department. 1864-1959.

Work 20/254 Care and maintenance of statues: instructions, 1869-1949.

Work 20/326 St. James's. The Mall Improvement (Approach). Admirality Arch to Charing Cross.

Work 21 Office of Works and successors: Ceremonial Files and Other Records 1727-1972.

Work 21/10/6 H.M. Queen Victoria. Diamond Jubilee 1897. Decorations at Albert Memorial 1897.

Work 21/10/7 ibid. Decorations of the Statue of the Queen in Kensington Gardens.

Corporation of London Record Office, London

Papers relating to the Prince Consort Memorial, Holborn Circus, c.1872-4. $<$ Holborn Valley Box 9.7>

Papers relating to the Prince Consort Memorial, Holborn Circus, c.1872-4. $<$ Holborn Valley Box 9.8>

Rowland Hill. Papers relating to the statue erected to the Rowland Hill Memorial Fund at the Royal Exchange 1880-1882. <Engineers Papers Misc. 1/17>

Royal Archives, Windsor

RA Add H1 The Prince Consort Memorial 1862-1863, 2 Bände.

RA Add H2 The Prince Consort Memorial 1862-1876, 14 Bände.

RA Add H5 The Albert Memorial. Minute-Book of the proceedings in Committee.

RA Add H4 Prince Consort Memorial. - Report January 1869. - G.G. Scott.

Camden Local Studies and Archives Centre, Holbom Library, London

Ephemera file on statue of Robert Stephenson in Euston Square, 1871.

St. Pancras Vestry Minutes, 1865 und 1866 [Cobden].

Royal Borough of Kensington and Chelsea Libraries, London

731.76 Vic. [Queen Victoria, Statue in Kensington]

Guildhall Library London, Manuscript Section

Peabody Committee <GL Ms Section MS 192>

\subsection{Gedruckte Quellen}

An account of the welsh memorial erected to His Royal Highness the Prince Consort, as a mark of loyalty to her Most Gracious Majesty the Queen, and of an affectionate respect and gratitude to the memory of Albert the Good, Tenby 1866.

AIRPLAY, F., Prince Albert. Why is he unpopular?, London 1856.

The Albert Memorial, A description of the Gothic shrine erected in memory of the late Prince Consort, from the designs of Sir Gilbert Scott, London 1892.

Anniversary of Trafalgar. Nelson's Monument, o. 0. o. J.

ARMSTRONG, John (Rev., Priest Vicar of Exeter Cathedral), A Paper on Monuments, Oxford 1854.

BACON, John, A letter to the Right Honorable Sir Robert Peel, Bart., M.P., on the appointment of a commission for prompting the cultivation and improvement of the Fine Arts with 
some suggestions respective a former commission, denominated the committee of taster, London 1843.

BAHLMAN, Dudley W.B. (Hg.), The Diary of Sir Edward Walter HAMILTON 1880-1885, Bd. 1 (1883-1885), Oxford 1972 .

BAIl Y, E., Nelson Memorial ( ${ }^{\circ} 39$ and 40), in: [Miscellaneous Papers, up].

BEAUMONT, Alfred, Description of a design for the Nelson Monument. ( ${ }^{\circ} 149$ ?), in: [Miscellaneous Papers, up].

BEHNES, William, The 'Nelson Testimonialk. A Letter to the Committee appointed to select a design for a Memorial of the achievements of the late Admiral Lord Viscout Nelson, London (31. Jan.) 1839.

BELL, John, Albert the Good. A few remarks on the proposed statue for the national memorial in Hyde Park, London [June] 1868.

-, Albert the Good. The Memorial Cross in Hyde Park, and the Statue, o. 0. 1869.

-, Memoranda in letters to R.H. Soden Smith, relating to his statue of Oliver Cromwell, o. O. 1890.

BOUTELL, Charles, The Hero and his example: a sermon preached in the Paris Church of Litcham, in the county of Norfolk, on the Evening of Thursday, November 18th 1852, together with a national anthem, by the Rev., M.A., Curate of Litcham, on the occasion of the public funeral of the late Arthur Duke of Wellington, London 1852.

BOWKER, Alfred, The King Alfred Millenary. A record of the proceeding of the National Commemoration, London 1902.

BRITTON, John, F.S.A, Brief account of a design for the Nelson Cenotaph and the British Naval Museum, as submitted to the committee for the Nelson Testimonial, January 1839, in: T.E. JONES (Hg.), A descriptive account of the literary works of John BRTTON, F.S.A., being the second part of his Auto-Biography, London 1849, S. 60-64.

BUCKLE, George Earle ( $\mathrm{Hg}$.), The Life of Benjamin Disraeli, Earl of Beaconsfield, Bd. 6 (1876-1881), London 1920.

CAMPBELL, Colin, Memorial to Lord Clyde, London 1864.

CARLYLE, Thomas, Letter-day pamphlets No. VII (July 1850): Hudson's statue, London 1850.

-, On heroes and hero-worship and the heroic in history, London 1901.

CARWRIGHT, John, Exhibition, at No.118 Pall Mall of the Drawings of the Hieronauticon or Naval Temple with many ornaments; as prepared for the Inspection of the Committee for Naval Celebration, London 1805.

CASE, Henry, Description of a design for the Nelson Monument, in: [Miscellaneous Papers, up].

-, Memorial of the Achievements of Horatio Lord Nelson, London 1839.

CHALMERS, Patrick, To the chairman and the members of the Board of Commissioners and Sewers, etc. [A memorial against the proposed statue to Sir Rowland Hill], o. O. 1881.

-, Who invented Uniform Penny Postage? [Change of inscription upon the city statue of Sir Roland Hill], o. O. 1884.

Civil Engineer and Architect's Journal, o. O. (August) 1839.

CLARKE, Edmund, Lectures on the Public Life and character of Oliver Cromwell, delivered (in substance) to the members of the Manchester Mechanic's Institution, in the spring of 1846, London 1847.

COLE, Henry, Diaries, 1853-1863, typescript edition und Index to the Henry Cole Diaries (1822-1882) held in the NAL, compiled by Elizabeth BONYTHON, unpublished typescript, 5 Bde, hier Bd. 3, London 1992.

-, Miscellaneous Pamphlets, o. O. o. J. <NAL Special collection $>$

-, Memorial to the Prince Consort. Observations (private and confidential), 1863, in: DERS., Miscellaneous Pamphlets, Bl. 119-123. 
-, Observations on the Design for the National Memorial to the Prince Consort, 11 March 1863, in: DERS., Miscellaneous Papers and Pamphlets, Bl. 125-128.

-, Memorandum on crosses and Shrines in England, 4th May 1863, in: DERS., Miscellaneous Pamphlets, Bl. 124-125.

[CONINGHAM, William (Esq.),] Lord Palmerston and Prince Albert. Letters, together with the ssupressed pamphlet ( entitled ,Palmerston: what has he done? ‘, by sone of the people‘, London 1854.

The Constitution Hill Archway and the Duke of Wellington Statue, London 1882.

Copy of a Report to Queen Victoria by the Executive Committee (subsequently the Trustees) of the Prince Consort Memorial Fund, together with a statement of the accounts 18621872, o. O. 1872 [Ms].

Correspondence and documents respecting the proposed monument to the memory of His Late Majesty King George III. Printed from the Committee Books. For the use of the Committee alone, London 1822.

The CROKER Papers. The Correspondence and diaries of the late right honourable John Wilson CROKER, hg. v. Louis J. JENNINGS, 3 Bde, London 1885.

The CROKER Papers 1808-1857, hg. v. Bernard POOL, London 1884, ND 1967.

CROWE, H.S. Wheatly, In defense of a king, Liverpool 1904.

CUNDALL, H.M., The Memorial to the Great Queen, London 1911.

DAFFORNE, James, The Albert Memorial, Hyde Park: its history and description, London o. J. [1878]

DEAN, James W., National Memorial to H.R.H. the late Prince Consort. >Treu und fest<: A poem in two books, London 1865

DENOON, D.G., The statue of King Charles at Charing Cross, London 1931 (repr. from the Transactions of the London and Middlesex Archaeological Society, New Series, Volume VI. - Part III.).

DERRICK, John M. (architect), Thomas GRIMSLEY (sculptor), Description of a design for the Nelson memorial, in: [Miscellaneous Papers, up].

On the designs of the Wellington Monument, by one of the people, London 1857.

DLKE, Charles Wentworth, The Great Exhibition Memorial. From the Critic, o. O. o. J.

DIRCKINCK-HOLMFELD, Constant, The Palmerston Monument erected form the ruins of the destroyed Danish Monarchy, Hamburg 1864.

DODGE, Walter Phelps, King Charles I. A study, London 1922.

DRIVER, Henry Austen, Byron and the Abbey. A few remarks upon the Poet, elicited by the rejection of his statue by the Dean of Westminster with suggestions for the erection of a national edifice to contain the monuments of our great men, London 1838.

DUFOUR, Alexander, Letter to the Nobility and Gentry composing the Committee for raising the Naval Pillar or Monument under the Patronage of His Royal Higness the Duke of Clarence; in answer to the Letter of John Flaxman, Sculptor, to the Committee on that Subject, London 1800.

EDGCUMBE, Richard, History of the Byron Memorial, London 1883.

EMERTON, J.A. (Rev.), A second letter to the Right Honorable Earl Granville, President of the Council, on the Memorial to His Royal Highness Albert, Prince Consort, London 1862.

EPSILON [i.e. John BELL], That the sentiment of the statue of the Prince in the National Prince Consort Memorial should be devout, and in harmony with the sacred character of the structure it is to occupy - which is a colossal shrine - and that the statue should be of marble, and not in bronze gilt. A letter to the editor of the Journal of the Society of Arts, $\mathbf{N}^{\circ}$ 2, o. O. o. J.

Explanation of Mr. Railton's design for the Nelson Monument, in: [Miscellaneous Papers, up]. 
FLAXIMAN, John, A letter to the Committee for raising the naval pillar or monument, under the patronage of His Royal Highness the Duke of Clarence, London 1799 [suggesting the erection of a colossal figure of Britannia on Greenwich Hill].

FORBES, Archibald, Havelock, London 1890.

FOWLER, Charles (architect), R.W. SIEVIER (sculptor), The proposed Monument, drawings and model, in: [Miscellaneous Papers, up].

Francis Bacon. The Commemoration of His Tercentenary at Gray's Inn, London o. J.

GARDINER, Samuel Rawon, Cromwell's Place in History. Founded on six lectures delivered in the University of Oxford, New York and Bombay 1897.

GAVEY, R.E., To the Lords and Gentlemen of the 'Nelson Monument Committee،. A Nelson Commemorial, consisting of a partially enclosed column, surmounted by a statue with a mausoleum interior, altogether forming a sculptural architective monumental pile commemorative of the hero. Height $\mathbf{1 7 0}$ feet. Proposed for erection, in: [Miscellaneous Papers, up].

GOLDICUTT, John, The Competition for the erection of the Nelson Monument critically examined, London 1841.

GRANVILLE, August B. (M.D., F.R.S.), A Letter to his Grace the Duke of Wellington on the Nelson Memorial and The Report of the Sub-Committee; with a double plate of Mr. Railton's and the Cast-Iron Corinthian Column, London 1839.

GRANVILLE, Walter Long B. (architect), Description of a triumphal column of cast iron to be erected in Trafalgar Square in Honour of Nelson and the Naval Victories of Great Britain, o. O. o. J.

-, Description of a Great Rostral Column of the Corinthian Order, two hundred and fourteen feet heigh, cast in Iron, with the base, capital and the statue in yellow bronze to be erected in Trafalgar Square to the Memory of Nelson, in: [Miscellaneous Papers, up].

The GREVILLE Memoirs. A Journal of the reigns of King George IV, King William IV and Queen Victoria by the late Charles C.F. GREVILLE, hg. v. Henry REEVE, Bd. 6, London 1888.

Groser, Horace G., Oliver Cromwell. The Hero of Puritan England London o. J.

Handbook to the Prince Consort National Memorial. Published by Authority of the Executive Committee, London 1874.

HARRAL, Thomas, The Apotheosis of Pitt; or, The crowning of the statue: A Masque, London 1822.

HOLMES, F.M., Four heroes of India: Clive - Warren Hastings - Havelock - Lawrence, London o. J.

HOPPER, Thomas [Architect], Design for the Nelson Testimonial with some observations, London 1839.

HORTON, Robert F., Oliver Cromwell. A study in personal religion, London 1897.

House of Commons Parliamentary Papers 1801-1995/96 [HoC PP]:

- Bill to place Public Statues within Metropolitan Police District under Control of Co. of Works and Public Buildings (Bills), Session 1854, Paper Nr. 85, Bd. 5, S. 605.

- Correspondence between Commissioners of Woods and Forests and Subscribers to Fund for Erecting statue of Duke of Wellington at Green Park, Session 1846, Paper Nr. 446, Bd. 43, S. 345.

- Correspondence with First Commissioner of Works relative to placing statue in Trafalgar Square to Memory of Sir H. Havelock, Session 1861, Paper Nr. 262, Bd. 50, S. 779.

- Correspondence relative to Wellington Statue, Session 1847, Paper Nr. 577, Bd. 57, S. 217.

- Est. of Sum required for defraying Expense of Monument to Memory of late Sir R. Peel, Session 1850, Paper Nr. 617, Bd. 34, S. 521.

- Letter from Sir Robert Peel to C.L. Eastlake, on Erection of monuments to Eminent Civilians, Session 1843, Paper Nr. 636, Bd. 30, S. 583.

- Memorial by Royal Academy of Arts to H.M. Govt. for Removal of Wellington Statue from Hyde Park Corner, Session 1884, Paper Nr. 148, Bd. 68, S. 283. 
- Report from Sub-Committee of Wellington Military Memorial, Author / Chair: John Henry Manners, 5th D. Rutland, Session 1848, Paper Nr. 553, Bd. 43, S. 367.

- Return of Arrangements between Commissioners of Woods and Forests and Committee for erecting Nelson Monument, statement of Plan for laying out Trafalgar Square, Session 1840, Paper Nr. 381, Bd. 29, S. 753.

- Return of Number of Public Statues in Metropolitan Police District, Session 1877, Paper Nr. 267, Bd. 71, S. 737.

- Return of Public Statues or Monuments in London belonging to Nation under charge of Chief Com. of Works, Session 1862, Paper Nr. 366, Bd. 30, S. 593.

- Return of Public Statues or Monuments in London belonging to Nation under charge of Chief Com. of Works, Session 1867-68, Paper Nr. 480, Bd. 55, S. 357.

- Supplementary Est. for Civil Services 1863-1864 (National Memorial for late Prince Consort), Session 1863, Paper Nr. 179, Bd. 37, S. 399.

- Treasury Min. on Completion of Wellington Monument, Session 1871, Paper Nr. 229, Bd. 56, S. 353.

- Treasury Min., Mar. 1871, appointing Cttee. to report on open air spaces available in vicinity of Palace of Westminster for Statues of Statesmen. Re of Cttee., Session 1871, Paper Nr. 248, Bd. 56, S. 363 .

The Wooden Idol of Berlin, o. O. o. J.

Spiritual interview with Lord Byron in which his Lordship gave his opinion and feelings about the monument and gossip about the literature of his own and the present day, with some interesting information about the spirit world. With notes explanatory and elucidatory, London $0 . \mathbf{J}$.

JoHnson, F.A. (Rev.), B.A., The Prince Consort Memorial. The proposed Scientific College for Suffolk, shewn to be a necessity, and the carrying out of the national designs of His late Royal Highness, with the reasons why it shoud be generally supported, London, ${ }^{2} \mathrm{o}$. J.

JoHnson, Henry, Temple Bar and State Pageants. An Historical Record of State Processions to the City of London, and of the Quaint Ceremonies connected therewith, London 1897.

JoHNSON, Lionel, The statue of King Charles I. at Charing Cross, London 1917.

JONES, T. E., Brief account of a design for the Nelson Cenotaph, and British Naval Museum, by John Britton, F.S.A., as submitted to the Committee for the Nelson Testimonial, January 1839 , in: DERS,, Appendix to Britton's Auto-Biography: containing biographical, archaeological, and critical essays, [Appendix zu: DERS.,] A descriptive account of the Literary Works of John Britton, F.S.A., \&c. (from 1800 to 1849), being a second part of his autobiography, London 1849, S. 60-64.

KELSEY, Richard, Samuel NIXON, The Nelson Monument. Description of the designs submitted to the committee, in: [Miscellaneous Papers, up].

KENNION, Rev. George Wyndham, Courage. Sincerity. Faith. A sermon preached at Christ Church, Mayfair, on Septuagesima Sunday 1902, in commemoration of the death of General Gordon, London 1902.

KIME, William Thomas, Albert the Good. A Nation's tribute of affection. To the Memory of a truly virtuous prince, London (9. Aug.) 1862.

Letter to the Queen on the state of the monarchy, by a friend of the people, London ${ }^{4} 1838$.

A Letter from the Earl of Westmorland to Earl Fortescue, on his speech in the House of Lords, Friday, July 24, 1857, respecting a monument to Field-Marshall Lord Raglan, London 1858 .

Letter to the Queen, on her retirement from public life, by one of Her Majesty's Most Loyal Subjects, London 1875.

A Letter to John Bull, Esq., from the British Bulldog, London 1876 (The British Lion's Message to the British People).

Letters from Prince Albert, Chairman of the Commission on the Fine Art, for the decoration of the Houses of Parliament, to Sir Charles Eastlake (Manuscripts), London 1842-1862. 
LINTON, W.J., Cetewayo and Dean Stanley [An imaginary dialogue concerning the monument to the Prince Imperial of France proposed to be placed in Westminster Abbey], London o. J.

London County Council, Return of outdoor memorials in London, other than statues on the exterior of, London 1910.

London County Council Minutes, 1888-1918.

Lord Shaftesbury and George Peabody. The story of two great public benefactors, London and Edinburgh 1896.

MACKAY, Charles, Life and times of Sir Robert Peel, Vol. IV, London 1851.

Memorial to Lord Clyde, London 1864.

Memorial to the late Lord Herbert. Report of the Proceedings at the Public Meeting held at Willi's Rooms, King Street, St. James's on Thursday, 28th November 1861. His Royal Highness the Duke of Cambridge, K.G. in the Chair, London 1862.

The National Memorial to His Royal Highness the Prince Consort, London 1873

Proposed Memorial to His Royal Highness the Prince Consort, London 1862.

Proposed National Memorial to His Royal Highness the Prince Consort, London o. J

Memorials of London $\mathrm{N}^{\circ} 2$ : Artist and Craftsmen, London, o. J. [1918].

Metropolitan Board of Works (Full Board). Minutes of proceeding, 1855-1888 [Angaben bezeichnen Dok.nummer/Seite].

A Minute Book of the Committee under whose superintendence the subscription was raised and the statue in honour of the duke of Wellington erected in the city of London, London 1845.

Miscellaneous papers relating to the Nelson Monument in Trafalgar Square, London 1838/39. [zit.: Miscellaneous Papers]

[M.M.,] Description of a drawn model proposed for THE MONUMENT intended to be erected in Trafalgar Square to the memory of Lord Nelson, with some collateral remarks [Motto: ,Exegi Monumentum?،], London 1839.

Public Monuments, a disgrace to England as exemplified in the colossal statues which disfigure the Metropolis and other cities, London 1853.

MORLEY, John, On popular culture. An inaugural address delivered in the Town Hall, Birmingham on the 5th of October 1876, London 1876.

-, Speech on the occasion of the unveiling of the Gladstone Statue Manchester, October, 23, 1901, o. O. 1901.

MOULE, Thomas, Description of the design of a Monument to Lord Nelson in Trafalgar Square, for construction in Portland Stone, London 1839.

Nelson Memorial. Report of the Committee to the adjourned meeting of competitors, assembled at the Thatched House, St. James, 4th March 1839. [Inman, W.S., Chairman].

Nelson Memorial Fund. Letter from the Rev. Mr. Hoole to James Walker, Esq.

Nelson's Monument, o. O. o. J.

To Horatio Viscount Nelson and Baron Nelson. The Lord Mayor, Aldermen and Common Council of the City of London, have caused this monument to be erected etc. [A description of Nelson's Monument in St.Paul's Cathedral], London 1818.

Notes on art, British Sculptors, sculpture and our public Monuments, London 1861.

OPIE, John [Professor of painting to the Royal Academy], Lectures on painting, delivered at the Royal Academy of Arts, with a letter on the proposal for a public memorial of the naval glory of Great Britain, London 1809.

Outram Testimonial, London 1861.

PALGRAVE, Francis Turner, The Albert Cross and English Monumental Sculpture, in: DERS., Essays on art, London and Cambridge 1866, S. 280-298.

-, Public Statues in London [Articles from The Broadway $\mathrm{N}^{\circ} 6 \&$ 7, Feb. \& March 1868], London 1968. 
PARISH, Charles, Description of a design for a national monument, to commemorate the glorious achievements of the late Admiral Lord Viscount Nelson. )Union fait forcer. (Model $\mathrm{N}^{\circ} 3$, Drawings $\mathrm{N}^{\circ} 25$.), in: [Miscellaneous Papers, up].

PARK, Patrick (sculptor), Memoir of a Design for the Monument to Lord Nelson, intended to be erected in the centre of Trafalgar Square, in: [Miscellaneous Papers, up].

PATMORE, Coventry, Shall Smith have a statue?, in: DERS., Principle in Art, London 1898, S. 205-209.

The Patriot Queen, London 1837.

PRIDDLE, L., History of the Boadicea Group [the one of Thomas Thomycroft]. Erected 1902 on the Victoria Embankment 1902.

Programme of the ceremony of the Unveiling of the Cavell Memorial, St. Martin's Place, on Wednesday, March 17th, at noon, London 1920.

Proposal for erecting a monument to Shakespeare. Read before a meeting of the society of arts, February 5, 1851; H.T. Horpe, Esq., M.P. in the Chair, London 1851.

Proposal for a scheme of National Health Promotion as a Memorial to King Edward VII., London o. J. (The National League for Physical Education and Improvement).

Queen Victoria Memorial. Address of the Queen Victoria Memorial Committee to His Majesty King George V., May 16, 1911; Speech of His Majesty King George V., 16 May 1911, London 1911.

-, Ceremonial to be observed at the Unveiling of the Queen Victoria Memorial accompanied by Her Majesty the Queen and their imperial Majesties the German Emperor and Empress, on Tuesday, the 16 May, 1911, at 12 o'clock noon, London 1911.

-, Report 1901-1911, London 1911.

'The Queen's best monument' and other articles, notes, poems and letters on the Queen. A memorial reprint from The Spectator, London $0 . J$.

RAUCH, C.D., Monument of Frederic the Great, King of Prussia, inaugurated May 31, Berlin 1851.

Reflections in Rhyme on the Wellington Memorial and the Column of Napoleon, London 1839.

Remarks on certain anonymous articles designed to render Queen Victoria unpopular with the explosure of their authorship, Gloucester 1864.

A few remarks on the style and execution of the New Houses of Parliament, the insertion of which was refused by a scientific journal for unknown reasons, with some additional observations occasioned by the debate on the subject in the House of Commons, the 14th February 1848 [to the editor of the ***], London 1848.

Remember Trafalgar Square! Tory Terrorism in 1887, London 1887.

ROBERTSON, Andrew, The Parthenon, adapted to the purpose of a National Monument to commemorate the victories of the late war, proposed to be erected in Trafalgar Square or Hyde Park, London 1839.

ROBERTSON, John, Royalism: a note on the Queen's Jubilee, London 1886.

ROBSON, Philip A., o.T., in: Journal of the Royal Institute of British Architects 8 (11. Mai 1911) S. 324-330.

ROSEBERY, Earl of, K.G., K.T., Oliver Cromwell. An Eulogy and an Appreciation. An address on the occasion of the unveiling of a statue of the Great Protector, London 0 . J.

ScoTT, George Gilbert, Suggestions respecting the proposed Memorial to His Royal Highness the Prince Consort, 29th April 1863, in: Cole, Miscellaneous Pamphlets, Bl. 114-115 Rs [mit eigener Paginierung].

-, Remarks on Mr. Cole's two papers on the Memorial to HRH The Prince Consort, May 1863, in: COLE, Miscellaneous Pamphlets, Bl. 111-113 Rs.

-, (Hg.) Personal and professional recollections by the late Sir George Gilbert Scott, London 1879, repr. New York 1977. 
Scraps relative to the Memorial to the Duke of Wellington, proposed to be erected on the Arch of Hyde Park Corner, London 1846.

Shakespeare's Day. A plea for a monument with a lyric from Romeo and Juliet, London 1864.

Proposed site for the National Monument of Shakespeare (in connection with Park improvements) suggested to the Ter-centenary celebration committee by one of its members, 0.0 . 1863.

SKELTON, John, Charles I., Edinburgh 1898.

SMIRKE, Sydney, Reasons for prefering an architectural to a sculptural design for the Nelson Monument, in: [Miscellaneous Papers, up].

SMTTH, C.H.(design), E.W. WYON (figures), Nelson Monument. Model $\mathrm{N}^{\circ} 40$, in: [Miscellaneous Papers, up].

SPEAIGHT, F.W., The Horse Guards' Parade. A suggested improvement by a citizen of London, London 1909.

Speech of John Hay at the unveiling of the bust of Sir Walter Scott in Westminster Abbey, May 21, 1897, London 1897.

SPIELMANN, Marion H., British Sculpture and Sculptors of To-Day, London u.a. 1901.

Statement of Subscriptions of the Memorial of the Achievements of the late Admiral Lord Viscount Nelson, January 1st 1841, London 1841.

Statue of Achilles in Hyde Park, London 1830.

The proposed statue to Oliver Cromwell at the Houses of Parliament, London 1910.

Public Statues, \& c. (London). Return to an order of the Honourable The House of Commons of the Public Statues or Public Monuments in London belonging to the Nation, in: HoC PP Session 1862, Paper $\mathrm{N}^{\circ}$ 366, Bd. 30, S. 593.

Public Statues. Return (...) of the Public Statues and Public Monuments in London, in: HoC PP Session 1867-1868, Paper $N^{\circ} 480$, Bd. 55, S. 357

STEPHENS, Walter, The proposed world's tribute to Shakespeare. A plea for the erection of a memorial statue and national Theatre, London u.a. o. J.

[SYDNEY,] S.'s Letter to the King; and the other correspondence, connected with the reported exclusion of Lord Byron's Monument from Westminster Abbey, London 1828.

TARRING, J., W. BEATTIE, Design for a national Monument to Lord Nelson, in: [Miscellaneous Papers, up].

The Trafalgar Square Lions, o. O. 1867.

Remember Trafalgar Square! Tory Terrorism in 1887 (Pall Mall Gazette Extra), London 1887.

This is the tree that Ben has raised, A political satire. Dedicated without permission in the G.O.M., by J.F.T.W., London o. J.

TRENCH, F.W., Memorandum, August 20, 1846, o. O. o. J.

A Tribute of high respect and gratitude to His Royal Highness the Duke of York, London o. J. TROTTER, Lionel J., The Bayard of India. A life of General Sir James Outram, London 1909.

Uncovering of the Memorial of the Exhibition of 1851 on the $10^{\text {th }}$ June 1863, in: Royal Horticultural Society Proceedings, Bd. 3 (1863) S. 265-272.

V. I. H., The Iron Duke or the Wellington Monument Removal, London 1882.

VIATOR, pseud., Why remove the statue? [of the Duke of Wellington at Hyde Park Corner], o. O. o. J. [London 1847].

[-,] The Duke of Wellington's Statue, Second letter from the Viator, o. O. o. J.

A voice from the tomb. A dialogue between Nelson and Wellington overheard at St.Paul's, London $\mathbf{o}$. $\mathbf{J}$.

The voice of the people as to the Waterloo Monument with observations on its principles and objects, its funds and management and the beneficial effects which may be derived from it, London 1816. 
Wagner, H.M., Rev., M.A, Vicar of Brighton, Wellington Memorial. A Sermon. Preached on the occasion of the Re-Opening of the Parish-Church Brighton, on Saturday, the 8th of April 1854, London 1854.

Waterlow Park 1900. Statue of Sidney Waterlow. Unveiled by HRH The Princess Louise (Duchess of Argyll), London 1900.

WESTMACOTT, William (architect), Samuel NIXON (sculptor), The Nelson Memorial, in: [Miscellaneous Papers, up].

What is the use of Kings? and how the question was answered: a national ballad (...), London 1872.

WHITE, Amold (Hg.), The letters of S.G.O., a series of letters on public affairs (...) published by the Times 1844-1888, Bd. 2, London o. J.

WHITE, S. Dewé, Revival of Jacobitism, in: The Westminster Review 146 (Oktober 1896) S. 417-426.

WILDE, W.R. (Surgeon), A Proposal relative to the Nelson Memorial. With a preface by Major-General Sir T.A. Larcom, Bart., K.C.B., London 1877.

WOOD, William, An Essay on national and sepulchral monuments, London 1808

\subsection{Periodika}

The Builder, $1842 \mathrm{ff}$.

Daily Chronicle, $1862 \mathrm{ff}$.

The Daily News, 1846-1912

The Daily Telegraph, $1855 \mathrm{ff}$.

Fraser's Magazine

The Guardian, $1846 \mathrm{ff}$.

The Illustrated London News, $1842 \mathrm{ff}$.

Lloyd's Weekly Newspaper, 1849 ff.

The Morning Post [and Daily Advertiser], $1848 \mathrm{ff}$.

The Nonconformist and Independent, $1841 \mathrm{ff}$.

The Pall Mall Gazette, 1865 ff.

Reynold's [Weekly] Newspaper, 1850 ff.

The Spectator, 1848-1907

The Standard, 1848-1916

The Times, $1848 \mathrm{ff}$.

The Nineteenth century, $1877 \mathrm{ff}$. 


\section{Literatur}

[Stand 2002]

AGULHON, Maurice, Pour une archéologie de la République. L'allégorie civique féminine, in: Annales E.S.C. 28 (1973) S. 5-34.

—, 1848 ou l'apprentissage de la République, 1848-1852, Paris 1973.

-, Fête spontanée et fêtes organisées à Paris en 1848, in: Jean EHRARD, Paul VIALLANEIX (Hg.), Les fêtes de la Révolution. Colloque de Clermont-Ferrand, Paris 1977, S. 243271.

—, La "statuomanie « et l'histoire, in: Ethnologie française 8 (1978) S. 145-172 [dt.: Die "Denkmalsmanie» und die Geschichtswissenschaft, in: DERS., Der vagabundierende Blick, S. 51-99].

—, Marianne au combat. L'imagerie et la symbolique républicaines de 1789 à 1880 , Paris 1979, ND 2001.

-, Politics, images, and symbols in Post-revolutionary France, in: Sean WILENTZ (Hg.), Rites of power: symbolism, ritual and politics since the Middle Ages, Philadelphia 1985 , S. $177-205$.

-, Une contribution au souvenir de Jean Jaurès: les monuments en places publiques, in: DERS., Histoire vagabonde, Bd. 1: Ethnologie et politique dans la France contemporaine, Paris 1988, S. 186-204.

—, Marianne au pouvoir. L'imagerie et la symbolique républicaines de 1880 à 1914, Paris 1989, ND 2001.

—, Pierre BONTE (Hg.), Marianne. Les visages de la République, Paris 1992.

-, Die nationale Frage in Frankreich: Geschichte und Anthropologie, in: FRANÇOIS, SiEgrist, Vogel (Hg.), Nation und Emotion, S. 56-65.

-, Der Mythos Garibaldi in Frankreich von 1882 bis heute, in: DERS., Der vagabundierende Blick, S. 154-199.

-, Der vagabundierende Blick. Für ein Verständnis politischer Geschichtsschreibung, Frankfurt a. M. 1995.

-, Von der Republik zum Vaterland. Die Geschichte der Marianne, in: Marie-Louise VON PLESSEN (Hg.), Marianne und Germania 1789-1889. Frankreich und Deutschland. Zwei Welten - eine Revue, Berlin 1996, S. 17-22 (AK).

AKaLTIN, Ferdi, Die Befreiungskriege im Geschichtsbild der Deutschen im 19. Jahrhundert, Freiburg 1997.

ALINGS, Reinhard, Die Berliner Siegessäule, Berlin 1990.

-, Monument und Nation. Das Bild vom Nationalstaat im Medium Denkmal - zum Verhältnis von Nation und Staat im deutschen Kaiserreich 1871-1918, Berlin, New York 1996 (Beiträge zur Kommunikationsgeschichte, 4).

ALLEN, Robert, The battle for the common: politics and populism in mid-Victorian Kentish London, in: SocH 22 (1997) S. 61-77.

ALTICK, Richard D., The shows of London, Cambridge/Mass., London 1978, S. 455-469.

AMALVI, Christian, Le 14 Juillet. Du "dies irae» à "Jour de fête«, in: NORA (Hg.), Les Lieux I, S. 421-472.

- Combats pour la mémoire à l'ombre du clocher et de la mairie: la Révolution au village de 1870-1914, in: Annuaire-Bulletin de la Société de 1'Histoire de France, Années 1989-1990, S. 23-40.

-, L'impossible consensus autour de la Révolution. L'Album du centenaire édité en 1889 par Désiré Lacroix et Auguste Challamel, in: Charle u.a. (Hg.), La France démocratique, S. 259-265.

AMANN, Armand, Les monuments à Jean-Jacques Rousseau, où la sculpture persécutée, in: C'est la faute à Rousseau. Révolution, Romantisme, République. L'image de Jean- 
Jacques Rousseau, Chambéry, Genève 1990 (AK Musée Savoisien Chambéry, Musée d'Art et d'Histoire Genève), S. 13-17.

ANDERSON, Benedict, Imagined communities. Reflections on the origin and spread of nationality, London rev. ed. 1991 [dt.: Die Erfindung der Nation. Zur Karriere eines folgenreichen Konzepts, Frankfurt a. M., New York 1996].

ANDERSON, Olive, The political uses of History in mid nineteenth-century England, in: P\&P 36 (1967) S. 87-105.

-, The growth of Christian militarism in mid-Victorian Britain, in: EHR 86 (1971) S. 4672.

ANDREE, Christian, Rudolf Virchow, in: Wilhelm TREUE, Ralf WINAU (Hg.), Berlinische Lebensbilder, Bd. 2: Mediziner, Berlin 1987 (Einzelveröffentlichungen der Historischen Kommission zu Berlin, 60), S. 175-190.

ANDREW, C.M., A.S. KANYA-FoRSTNER, The French ,Colonial party: its composition, aims and influence, 1885-1914, in: HJ 14 (1971) S. 99-128.

ANGENOT, Marc, Le centenaire de la Révolution 1889, Montreal 1989.

APRILE, Sylvie, La République au Salon: vie et mort d'une forme de sociabilité politique (1865-1885), in: RHMC 38 (1991) S. 473-487.

-, La II ${ }^{e}$ République et le Second Empire, 1848-1870 du Prince Président à Napoléon III, Paris 2000 (Histoire politique de la France).

D'ARCY, Fergus A., Charles Bradlaugh and the English Republican Movement 1868-78, in: HJ 25 (1982) S. 367-383.

ARNDT, Karl, Denkmaltopographie als Programm und Politik. Skizze einer Forschungsaufgabe, in: MAI, WAETZOLDT (Hg.), Kunstverwaltung, S. 165-190.

ARNDT, Monika, Ehre, wem Ehre gebührt? Karikaturen zur »Denkmalinflation« der wilhelminischen Zeit, in: Gerhard LANGEMEYER u.a. (Hg.), Bild als Waffe. Mittel und Motive der Karikatur in fünf Jahrhunderten, München 1984, S. 431-440.

-, Die »Ruhmeshalle« im Berliner Zeughaus. Eine Selbstdarstellung Preußens nach der Reichsgründung, Berlin 1985 (Die Bauwerke und Kunstdenkmäler von Berlin, Beiheft 12).

ARNSTEN, Walter L., Queen Victoria opens Parliament: the Disinvention of Tradition, in: HR 63 (1990) S. 178-194.

-, The Warrior Queen: Reflections on Victoria and her world, in: Albion 30 (1998) S. 128.

ASSMANN, Aleida, Zum Problem der Identität aus kulturwissenschaftlicher Sicht, in: Rolf LINDNER (Hg.), Die Wiederkehr des Regionalen. Über neue Formen kultureller Identität, Frankfurt a. M., New York 1994, S. 13-35.

ASSMANN, Jan, Das kulturelle Gedächtnis. Schrift, Erinnerung und politische Identität in frühen Hochkulturen, München ${ }^{3} 2000$.

AUERBACH, Jeffrey A., Exhibiting the Nation: British national identity and the Great Exhibition of 1851, Ann Arbor 1995.

- The Great Exhibition of 1851: a nation on display, New Haven, London 1999.

AWERBUCH, Marianne, Heinrich von Treitschke, in: ERBE ( $\mathrm{Hg}$.), Berlinische Lebensbilder, Bd. 4, S. 209-230.

BABELON, Jean-Pierre, La Cour Carrée du Louvre. Les tentatives des siècles pour maitriser un espace urbain mal défini, in: Bulletin Monumental 142 (1984) S. 41-81.

BAEUMER, Max L., Lutherfeiem und ihre politische Manipulation, in: GRMM, HERMAND (Hg.), Deutsche Feiem, S. 46-61.

BAKER, Alan R. H., Introduction: on ideology and landscape, in: DERS., Gideon BIGER (Hg.), Ideology and landscape in historical perspective. Essays on the meanings of some places in the past, Cambridge 1992, S. 1-14.

BARBER, Sarah, Regicide and republicanism. Politics and ethics in the English Revolution, 1646-1659, Edinburgh 1998. 
BARCLAY, David E., Ritual, ceremonial and the "Invention « of Monarchical Tradition in nineteenth century Prussia, in: Heinz DUCHHARDT, Richard A. JACKSON, David STURDY (Hg.), European Monarchy. Its evolution and practice from Roman Antiquity to Modern Times, Stuttgart 1992, S. 207-220.

-, Frederick William IV and the Prussian Monarchy, 1840-1861, Oxford 1995.

BAUER, Franz J., Gehalt und Gestalt in der Monumentalsymbolik. Zur Ikonologie des Nationalstaats in Deutschland und Italien 1860-1914, München 1992 (Schriften des Historischen Kollegs. Vorträge, 30).

BAUERKÄMPER, Amd, Die »radikale Rechte« in Großbritannien. Nationalistische, antisemitische und faschistische Bewegungen vom späten 19. Jahrhundert bis 1945, Göttingen 1991 (Kritische Studien zur Geschichtswissenschaft, 93).

BAYLEY, Stephen, The Albert Memorial, London 1981.

BAYLY, Christopher Alan, Indian society and the making of the British Empire, Cambridge 1988, ND 2001 (The New Cambridge History of India II.1).

BECKER, Annette, Monuments aux morts après la guerre de sécession et la guerre de 18701871: un legs de la guerre nationale?, in: Guerres mondiales et conflits contemporains 167 (1992) S. 23-40.

-, Der Kult der Erinnerung nach dem Großen Krieg. Kriegerdenkmäler in Frankreich, in: JEISMANN, KOSELLECK (Hg.), Der politische Totenkult, S. 315-324.

BECKER, Frank, Bilder von Krieg und Nation. Die Einigungskriege in der bürgerlichen Öffentlichkeit Deutschlands 1864-1913, München 2001 (Ordnungssysteme. Studien zur Ideengeschichte der Neuzeit, 7).

BECKER, Jean-Jacques, Stéphane AUDON-ROUZEAU, La France, la nation, la guerre: 18501920, Paris 1995.

BEHRENBECK, Sabine, Alexander NƯTZENADEL, Politische Feiern im Nationalstaat. Perspektiven eines Vergleichs zwischen Italien und Deutschland, in: DIES. (Hg.), Inszenierungen des Nationalstaats, S. 9-26.

BELGUM, Kirsten, Displaying the Nation: A view of nineteenth-century monuments through a popular magazine, in: CEH 26 (1993) S. 457-474.

BELL, David, Recent Works on Early Modern French National Identity, in: JMH 68 (1996) S. 84-113.

BELlanger, Claude u.a. (Hg.), Histoire générale de la Presse Française, Bd. 2: De 1815 à 1871, Paris 1969, und Bd. 3: De 1871 à 1940, Paris 1972.

BEN-AMOS, Avner, Les funérailles de Victor Hugo. Apothéose de l'événement spectacle, in: NORA (Hg.), Les lieux I., S. 473-522.

-, The sacred center of power: Paris and the state funerals of the French Third Republic, in: Journal of Interdisciplinary history 22 (1991) S. 27-48.

-, Monuments and memory in French Nationalism, in: History and Memory 5 (1993) S. 50-81.

BENREKASSA, Georges, Entre l'individu et l'auteur: Jean Jacques Rousseau, grand écrivain national (1878-1912), ou sdans quel état on entre dans l'histoires, in: DERS., Fables de la Personne. Pour une histoire de la subjectivité, Paris 1985, S. 135-217.

BENSIMON, Fabrice, Les Britanniques face à la révolution française de 1848, Condé-surNoireau 2000.

BENSOUSSAN, Georges, L'Idéologie du rejet. Enquête sur "Le Monument Henry" ou archéologie du fantasme antisémite dans la France de la fin du XIX siècle, Paris 1993.

BERDOLL, Barry, Le Panthéon/Sainte Geneviève au XIX siècle. La monumentalité à l'épreuve des révolutions idéologiques, in: Le Panthéon. Symbole des révolutions. De l'Église de la Nation au Temple des grands hommes, Paris 1989, S. 175-233.

BERGHOFF, Hartmut, Dieter ZIEGLER, Pionier und Nachzügler. Kategorien für den deutschbritischen Vergleich?, in: DIES. (Hg.), Pionier oder Nachzügler?: Vergleichende Studien 
zur Geschichte Großbritanniens und Deutschlands im Zeitalter der Industrialisierung, FS für Sidney Pollard (Veröffentlichungen des ADEF, 28), Bochum ${ }^{2} 1996$, S. 15-28.

BIEFANG, Andreas, Die Deutsche Fortschrittspartei in Preußen 1861-1867. Nationalpreußisch oder deutsch-national?, in: GG 27 (1997) S. 361-384.

BIRKE, Adolf M., Lothar KETTENACKER (Hg.), Bürgertum, Adel und Monarchie. Wandel der Lebensformen im Zeitalter des bürgerlichen Nationalismus, München u.a. 1989 (Prinz-Albert-Studien, 7).

—, Nation und Konfession. Varianten des politischen Katholizismus im Europa des 19. Jahrhunderts, in: HJb 116 (1996) S. 395-416.

BISCHOFF, Ulrich (Hg.), Denkmäler für die Befreiungskriege in Deutschland 1813-1815, 2 Bände, Berlin 1977.

_-, Skulptur und Plastik, Stuttgart 1985 (Kunsttheorie und Kunstgeschichte des 19. Jahrhunderts in Deutschland. Texte und Dokumente, 3).

BIVER, Marie-Louise, La Colonne Napoléone et le Camp de Boulogne-sur-Mer, in: Revue de l'Institut Napoléon 95 (1965) S. 76-83.

-, Fêtes révolutionnaires à Paris, Paris 1979.

BLACK, Jeremy, Maps and Politics, London 1997.

BLACKBOURN, David, A sense of place. New directions in German History, London 1999 (Annual lectures of the German Historical Institute London. The 1998 Annual Lecture).

-, Geoff ELEY, The peculiarities of German History. Bourgeois society and politics in Nineteenth-Century Germany, Oxford, New York 1984 [dt.: Mythen deutscher Geschichtsschreibung: die gescheiterte bürgerliche Revolution von 1848, Frankfurt a.M. 1980.].

BLACKWOOD, John, London's immortals. The complete outdoor commemorative statues, London 1989.

BLANCH, M. D., British Society and the War, in: WARWICK (Hg.), The South African War, S. 210-238.

BLANNING, Timothy C.W. (Hg.), The nineteenth century: Europe 1789-1914, Oxford 2000.

BLASCHKE, Olaf, Frank-Michael KUHLEMANN, Religion in Geschichte und Gesellschaft. Sozialhistorische Perspektiven für die vergleichende Erforschung religiöser Mentalitäten und Milieus, in: DIES. (Hg.), Religion im Kaiserreich. Milieus - Mentalitäten - Krisen, Gütersloh 1996 bzw. ${ }^{2} 2000$ (Religiöse Kulturen der Moderne, 2), S. 7-56.

BLASIUS, Dirk, Friedrich Wilhelm IV. Persönlichkeit und Amt, in: HZ 263 (1996) S. 589 607.

BLESSING, Werner K., Der monarchische Kult, politische Loyalität und die Arbeiterbewegung im deutschen Kaiserreich, in: Gerhard A. RITTER (Hg.), Arbeiterkultur, Königstein/Ts. 1979, S. 185-208.

BLOCH, Marc, Mémoire collective, tradition et coutume. À propos d'un livre récent, in: Revue de synthèse historique 39/40 (1925) S. 73-83.

-, Pour une histoire comparée des sociétés européennes, in: DERS., Mélanges historiques, Bd. 1, Paris 1963.

BLOCH, Peter, Anmerkungen zu Berliner Skulpturen des 19. Jahrhunderts, in: JbPK 8 (1970) S. 162-190.

-, Das Kreuzberg-Denkmal und die patriotische Kunst, in: JbPK 11 (1973) S. 142-159.

-, Denkmäler in Berlin. Rehabilitierung und Restaurierung, in: JbPK 13 (1976) S. 45-70.

-, Die Berliner Bildhauerei des 19. Jahrhunderts und die Antike, in: Willmuth ARENHOVEL, Christa SCHREIBER (Hg.), Berlin und die Antike. Ergänzungsband zum AK, Berlin 1979, S. 395-429.

-, Heroen der Kunst, Wissenschaft und Wirtschaft. Zierbrunnen und »freie Kunst", in: TRIER, WEYRES (Hg.), Kunst des 19. Jahrhunderts, S. 281-348.

-, Denkmal und Denkmalkult, in: DERS., EINHOLZ, vON SIMSON (Hg.), Ethos und Pathos, S. 191-205. 
-, Waldemar GRZMMEK, Die Berliner Bildhauerschule im 19. Jahrhundert. Das klassische Berlin, Frankfurt a. M., Berlin, Wien 1978 bzw. Berlin ${ }^{2} 1994$.

-, Sibylle EINHOLZ, Jutta vON SIMSON (Hg.), Ethos und Pathos. Die Berliner Bildhauerschule 1786-1914. Beiträge, Berlin 1990 (AK).

BOER, Pim den, Willem FruJHOFF (Hg.), Lieux de mémoire et identités nationales, Amsterdam 1993.

BOGART, Michele H., Public Sculpture and the civic ideal in New York City, 1890-1930, Chicago u.a. 1989.

BOIME, Albert, Hollow Icons: The politics of sculpture in nineteenth century France, Kent, Ohio, London 1987.

-, The unveiling of the national icons. A plea for patriotic iconoclasm in a nationalist era, Cambridge 1998.

BoIS, Jean-Pierre, Histoire des 14 juillet, 1789-1919, Rennes 1991.

BOLLENBECK, Georg, Bildung und Kultur. Glanz und Elend eines deutschen Deutungsmusters, Frankfurt 1994.

BONNIOT, Roger, Le >déboulonneur` Courbet et la réédification de la Colonne Vendôme. Interventions de ses amis saintais en faveur de Gustave Courbet en exil (1875), in: GBA 109 (1967) S. 227-244.

BOOKMANN, Hartmut, Denkmäler. Eine Utopie des 19. Jahrhunderts, in: GWU 3 (1977) S. 160-173.

BORG, Alan, War Memorials from antiquity to the present, London 1991.

BORST, Arno, Barbarossas Erwachen - zur Geschichte der deutschen Identität, in: Odo MARQUARD, Karlheinz STIERLE (Hg.), Identität, München ${ }^{2} 1996$ (Poetik und Hermeneutik, 8), S. 17-60.

BOURDIEU, Pierre, Social space and symbolic power, in: DERS., In other words. Essays towards a reflexive sociology, Cambridge 1990, S. 123-139.

- , Sozialer Raum und »Klassen«, Leçon sur la leçon, zwei Vorlesungen, Frankfurt a. M. ${ }^{2} 1991$.

Bourel, Dominique, Les Juifs à Berlin et à Paris, in: MrECK, Mơller, Voss (Hg.), Paris und Berlin in der Revolution, S. 229-239.

BOUVIER, Beatrix W., Die Märzfeiem der sozialdemokratischen Arbeiter: Gedenktage des Proletariats - Gedenktage der Revolution. Zur Geschichte des 18. März, in: DƯDING u.a. (Hg.), Öffentliche Festkultur, S. 334-351.

-, Es wird kommen der Mai ... Zur Ikonographie des Arbeitermai im Kaiserreich, in: AfS 33 (1993) S. 570-585.

BoYCE, George, James CuRRan, Pauline Wingate (Hg.), Newspaper History from the seventeenth century to the present day, London 1978.

BRAEMBUSSCHE, A.A. van den, Historical explanation and comparative method: Towards a theory of the history of society, in: History and Theory 28 (1989) S. 1-24.

BRAKE, Laurel, Aled JONES, Lionel MADDEN, Investigating Victorian Journalism, Houndmills 1990.

BRESC-BAUTIER, Geneviève, Anne PINGEOT, Sculptures des jardins du Louvre, du Carrousel et des Tuileries, 2 Bände, Paris 1986.

BRETT, Peter, Political Dinners in early nineteenth-century Britain: Platform, meeting place and battleground, in: History 81 (1996) S. 527-552.

BREUILLY, John, Nationalism and the state, Manchester 1982.

- Civil society and the public sphere in Hamburg, Lyon and Manchester, 1815-1850, in: KOOPMANN, LAUSTER (Hg.), Vormärzliteratur, Bd. 1, S. 15-39.

BRIGGS, Asa, Saxons, Normans and Victorians, in: DERS., The collected essays of Asa Briggs, Bd. 2: Images, problems, standpoints, forecasts, Brighton 1985, S. 215-235.

-, The Age of Improvement 1783-1867, London ${ }^{7} 1988$.

-, Victorian Cities, repr. London 1990. 
BROWN, Lucy, The growth of a National Press, in: BRAKE, JONES, MADDEN (Hg.), Investigating Victorian Journalism, S. 133-140.

BRUBAKER, Rogers, Citizenship and Nationhood in France and Germany, Cambridge/Mass., London 1992.

BRUCH, Rüdiger vom, Kunst- und Kulturkritik in führenden bildungsbürgerlichen Zeitschriften des Kaiserreichs, in: Ekkehard MAI u.a. (Hg.), Ideengeschichte und Kunstwissenschaft. Philosophie und Bildende Kunst im Kaiserreich, Berlin 1983 (Kunst, Kultur und Politik im deutschen Kaiserreich, 3), S. 313-347.

BRƯCKNER, Wolfgang, Zugänge zum Denkmalwesen des 19. Jahrhunderts. Kollektive Trägerschaften und populäre Formen des Gedenkens, in: MAl, SCHMIRBER (Hg.), Denkmal Zeichen - Monument, S. 13-18.

BRUNN, Gerhard, Die deutsche Einigungsbewegung und der Aufstieg Berlins zur deutschen Hauptstadt, in: DERS., Wolfgang SCHIEDER (Hg.), Hauptstädte in europäischen Nationalstaaten, München, Wien 1983 (Studien zur Geschichte des 19. Jahrhunderts, 12), S. 15-33.

-, Germania und die Entstehung des deutschen Nationalstaates. Zum Zusammenhang von Symbolen und Wir-Gefühl, in: Rüdiger VolGT ( $\mathrm{Hg}$.), Symbole der Politik, Politik der Symbole, Opladen 1989, S. 101-122.

BRUYN, Günter de, Königin Luise, in: FrançOIS, Schulze (Hg.), Deutsche Erinnerungsorte II, S. 286-298.

BURCKHARDT, Johannes, Reformations- und Lutherfeiern. Die Verbürgerlichung der reformatorischen Jubiläumskultur, in: DÚDING u.a. (Hg.), Öffentliche Festkultur, S. 212-236.

Busco, Marie F., The ,Achilles, in Hyde Park, in: Burlington Magazine 130 (1988) S. 920-924.

BUTLER, Ruth, >Long live the Revolution, the Republic, and especially the Emperor!c: The political sculpture of Rude, in: Henry A. MLLON, L. NOCHLIN (Hg.), Art and architecture in the service of politics, Cambridge/Mass., London 1978 bzw. ${ }^{2} 1980$, S. 92-107.

-, The politics of public monuments. Rodin's Victor Hugo and Balzac, in: Sculpture Review 47 (1998) S. 8-15.

CAHM, Eric, The Dreyfus Affair in french society and politics, London 1996.

CAIN, Peter, A. G. HOPKINS, British Imperialism: Innovation and expansion 1688-1914, London, New York 1993.

CANINI, Gérard, The school battalions in the east, 1882-92: reasons for failure, in: TOMBS, Nationhood and nationalism, S. 248-254.

CANNADINE, David, The transformation of civic ritual in Modern Britain: The Colchester Oyster Feast, in: P\&P 94 (1982) S. 107-30.

-, The context, performance and meaning of ritual: The British Monarchy and the Invention of Tradition', c. 1820-1977, in: HOBSBAWM, RANGER (Hg.), The invention of tradition, S. 101-164.

-, Introduction: Divine rights of kings, in: DERS., Simon PRICE (Hg.), Rituals of royalty: power and ceremonial in traditional societies, Cambridge, New York, Oakleigh 1992, S. $1-19$

-, Florence Nightingale, in: DERS., History in our time, S. 199-207.

-, History in our time, New Haven, London 1998.

-, Patriotism, in: DERS., History in our time, S. 89-95.

-, Queen Victoria, in: DERS., History in our time, S. 39-47.

-, Elizabeth HAMMERTON, Conflict and consensus on a ceremonial occasion: The Diamond Jubilee in Cambridge in 1897, in: HJ 24 (1981) S. 111-146.

DE CASO, Jacques, Rodin and the cult of Balzac, in: Sculpture Review 47 (1998) S. 279284.

CASSELLE, Pierre, Les publications officielles parisiennes: une source pour l'histoire de la capitale entre 1800 et 1870, in: Recherches Contemporaines 2 (1994) S. 131-147. 
ChaMOUARD, Patrick, La guerre de 1870-1871 et la défense de Paris, in: WELL (Hg.), La perspective, S. 95-120.

—, Un après-midi d'été 1883: l'inauguration de la statue, in: WEILL ( $\mathrm{Hg}$.), La perspective, S. 157-165.

CHANET, Jean-François, ,Les invalides de la Libertéc. Les débats sur le Panthéon et le choix des grands hommes de la troisième à la cinquième République, in: CHARLE u.a. (Hg.), La France démocratique, S. 267-276.

CHARLE, Christophe u.a. (Hg.), La France démocratique (combats, mentalités, symboles). Mélanges offerts à Maurice Agulhon, Paris 1998 (Histoire de la France au XIX et XX $^{\mathfrak{c}}$ siècle, 45).

CHARTIER, Roger, Die Welt als Repräsentation, in: Matthias MIDDELL (Hg.), Alles Gewordene hat Geschichte, Leipzig 1994, S. 320-355.

CHASE, Malcolm, From millennium to anniversary: the concept of Jubilee in late eighteenthand nineteenth-century England, in: P\&P 129 (1990) S. 132-147.

CHAUDONNERET, Marie-Claude, La Figure de la République. Le concours de 1848, Paris 1987 (Notes et Documents de France, 13).

-, La Révolution de 1848 et les arts en France, in: Ilja MECK, Horst MOLLER, Jürgen Voss (Hg.), Paris und Berlin in der Revolution 1848, Sigmaringen 1995, S. 299-320.

CHOURY, Maurice, Bonjour, Monsieur Courbet!, Paris 1969.

CLARK, Christopher, The Wars of Liberation in Prussian Memory: Reflections on the memorialization of War in early nineteenth-century Germany, in: JMH 68 (1996) S. 550576.

COETZEE, Frans, Marilyn Shevin COETZEE, Rethinking the Radical Right in Germany and Britain before 1914, in: JCH 21 (1986) S. 515-537.

COHEN, William, Symbols of Power: Statues in Nineteenth-century Provincial France, in: CSSH 31 (1989) S. 491-513.

COLLEY, Linda, The apotheosis of George III: Loyalty, royalty and the British nation, 1760-1820, in: P\&P 102 (1984) S. 94-129.

-, Whose nation? Class and national consciousness in Britain 1750-1830, in: P\&P 113 (1986) S. 97-117.

-, Britishness and Otherness: an argument, in: Ronald G. ASCH (Hg.), Three nations - a common history?: England, Scotland, Ireland and British History c. 1600-1920, Bochum 1993 (ADEF-Veröffentlichungen, 23), S. 273-296.

- The reach of the state, the appeal of the nation. Mass arming and political culture in the Napoleonic Wars, in: Lawrence STONE ( $\mathrm{Hg}$.), An imperial state at war. Britain from 1689 to 1815 , London 1994 , S. 165-184.

—, Britons. Forging the Nation 1707-1837, New Haven, London 1992, ND 1996.

COLLIN, Stefan, French Contrasts: From the Panthéon to Poet's Comer, in: DERS, English Pasts. Essays in History and Culture, Oxford 1999, S. 38-66.

CONACHER, James B., Britain and the Crimea, 1855-56. Problems of war and peace, Basingstoke u.a. 1987.

CONFINO, Alon, The Nation as a local metaphor: Heimat, National memory and the German Empire, 1871-1918, in: History and Memory 5 (1993) S. 42-86.

-, Die Nation als lokale Metapher: Heimat, nationale Zugehörigkeit und das Deutsche Reich 1871-1918, in: ZGW 44 (1996) S. 421-435.

-, The Nation as a local metaphor. Württemberg, Imperial Germany, and national memory, 1871-1918, Chapel Hill, London 1997.

-, Collective Memory and Cultural history: Problems of method, in: AHR 102 (1997) S. 1386-1403.

CONNERTON, Paul, How societies remember, Cambridge 1989, ND 1998.

CoRNS, Thomas N. (Hg.), The royal image. Representations of Charles I, Cambridge 1999. 
COSGROVE, Denis E., Social formation and symbolic landscape, London, Sydney 1984, ND Madison/Wis. 1998.

COULTER, John Wesley, Great Britain in Hawaii: The Captain Cook Monument, in: The Geographical Journal 130 (1964) S. 256-301.

CROSSICK, Geoffrey, La bourgeoisie britannique au $19^{\complement}$ siècle. Recherches, approches, problématiques, in: Annales 53 (1998) S. 1089-1130.

CUBITT, Geoffrey (Hg.), Imagining nations, Manchester und New York 1998

CULLEN, Michael S., Uwe KIELING, Der deutsche Reichstag. Geschichte eines Parlaments, Berlin 1992.

Cunningham, Hugh, The language of patriotism, in: SAMUEL (Hg.), Patriotism I, S. 57 89.

CZIHAK, Hans, Der Kampf um die Ausgestaltung des Friedhofes der Märzgefallenen im Berliner Friedrichshain, in: Walter ScHMIDT (Hg.), Demokratie, Liberalismus und Konterrevolution. Studien zur deutschen Revolution von 1848/49, Berlin 1998, S. 549-561.

DANIEL, Ute, »Kultur« und »Gesellschaft«, Überlegungen zum Gegenstandsbereich der Sozialgeschichte, in: GG 19 (1993) S. 69-99.

-, Kompendium Kulturgeschichte. Theorien, Praxis, Schlüsselwörter, Frankfurt a. M. ${ }^{3} 2002$

DANIELS, Stephen, Mapping national identities: the culture of cartography, with particular reference to the Ordinance Survey, in: CUBITT (Hg.), Imagining nations, S. 112-131.

DANN, Otto, Conclusion. Sociabilité und Vereinsbildung, in: Étienne FrançOIS (Hg.), Sociabilité et société bourgeoise en France, en Allemagne et en Suisse, 1750-1850, Paris 1986, S. 313-316.

-, Nation und Nationalismus in Deutschland, 1770-1990, München ${ }^{3} 1996$.

DARBY, Elisabeth Susan, Statues of Queen Victoria and Prince Albert. A study in Commemorative and Portrait Statuary, 1837-1924, 2 Bde, London 1983, unveröffentlichtes Ms. $<$ Courtauld Institute of Art, London, B 467>

-, Nicola SMTTH, The cult of the Prince Consort, New Haven, London 1983.

DAUM, Andreas W., Wissenschaftspopularisierung im 19. Jahrhundert. Bürgerliche Kultur, naturwissenschaftliche Bildung und die deutsche Öffentlichkeit, 1848-1914, München 1998.

DAVIS, John, Reforming London. The London Government Problem, 1855-1900, Oxford 1988.

DEBRETT's Queen Victoria's Jubilees 1887 \& 1897, compiled by Carolin CHAPMAN; Paul RABEN, London 1977.

DEINET, Klaus, Die mimetische Revolution oder die französische Linke und die ReInszenierung der Französischen Revolution im 19. Jahrhundert (1830-1871), Stuttgart 2001 (Beihefte der Francia, 50).

DELAPORTE, Christian, Presse et culture de masse en France (1880-1914), in: RH 299 (1998) S. 93-121.

DEMANDT, Alexander, Mommsen in Berlin, in: TREUE, GRUNDER (Hg.), Berlinische Lebensbilder, Bd. 3, S. 157-173.

DEMPS, Laurenz, Berlin - Wilhelmstraße. Eine Topographie preußisch-deutscher Macht, Berlin 1994.

—, Der Pariser Platz. Der Empfangssalon Berlins, Berlin 1995.

-, Der Invalidenfriedhof. Denkmal preußisch-deutscher Geschichte in Berlin, Berlin 1996.

-, Der Berliner Dom in der zeitgenössischen Architektur und der politischen Kritik, in: Detlef PLOSE (Red.), Der Berliner Dom, S. 70-79.

DENIS, Marie-Noëlle, Fêtes et manifestations dans la ville impériale de Strasbourg (18701918). Entre dérision et blasphème, in: Revue des Sciences Sociales de la France de l'Est 21 (1994) S. 12-17. 
DENOON, D. G., The statue of King Charles I. at Charing Cross, in: Transactions of the London \& Middlesex Archaeological Society 6 (1933) S. 460-486.

DETTMER, Klaus, Die Grundsteinlegungsurkunden der Siegessäule. Drei Begründungen für ihren Bau und eine für ihren Standortwechsel, in: Berlin in Geschichte und Gegenwart, Berlin 1984, S. 49-69.

DIERS, Michael, Nagelmänner. Propaganda mit ephemeren Denkmälern im Ersten Weltkrieg, in: DERS., Schlagbilder. Zur politischen Ikonographie der Gegenwart, Frankfurt a. M. 1997, S. 78-100 [erstmals in DERS. (Hg.), Mo(nu)mente. Formen und Funktionen ephemerer Denkmäler, Berlin 1993, S. 113-135].

DIETRICH, Richard, Verfassung und Verwaltung, in: Hans HERZFELD (Hg.), Berlin und die Provinz Brandenburg im 19. und 20. Jahrhundert, Berlin 1968 (Veröffentlichungen der Historischen Kommission zu Berlin, 25), S. 183-251.

DORNER, Andreas, Politischer Mythos und symbolische Politik. Der Hermannmythos: zur Entstehung des Nationalbewußtseins der Deutschen, Hamburg 1996.

DRESCHER, S., Whose abolition? Popular pressure and the ending of the British slave trade, in: P\&P 143 (1994) S. 136-166.

DRESSER, Madge, Britannia, in: SAMUEL (Hg.), Patriotism, Bd. 3, S. 26-49.

DRISKEL, Michael Paul, As befits a legend: building a tomb for Napoleon, 1840-1861, Kent, Ohio, London 1993.

DRIVER, Felix, David GILBERT (Hg.), Imperial cities. Landscape, display and identity, Manchester und New York 1999.

DROUIN, Michel (Hg.), L'affaire Dreyfus de A à Z, Paris 1994.

DROZ, Jacques, Der Nationalismus der Linken und der Nationalismus der Rechten in Frankreich (1871-1914), in: HZ 210 (1970) S. 1-13.

DUBoIs, Claude-Gilbert, Qu'est-ce qu'une nation? Conscience d'identité et respect de l'altérité, in: DERS., L'imaginaire de la Nation, 1792-1992. Colloque européen de Bordeaux, Bordeaux 1991, S. 19-31.

DUBY, Charles, L'histoire culturelle, in: RIOUX, SIRINELLI (Hg.), Pour une historie culturelle, S. 427-432.

DUCHHARDT, Heinz, Anspruch und Architektur: das Beispiel Berlin, in: Forschungen zur Brandenburgischen und Preußischen Geschichte NF 1 (1991) S. 31-52.

DUDING, Dieter, Organisierter gesellschaftlicher Nationalismus in Deutschland (18081847). Bedeutung und Funktion der Turner- und Sängervereine für die deutsche Nationalbewegung, München 1984 (Studien zur Geschichte des 19. Jahrhunderts, 13).

-, Peter FrIEdemanN, Paul MÜNCH (Hg.), Öffentliche Festkultur. Politische Feste in Deutschland von der Aufklärung bis zum Ersten Weltkrieg, Reinbek bei Hamburg 1988.

-, Einleitung. Politische Öffentlichkeit - politisches Fest - politische Kultur, in: DIES. (Hg.), Öffentliche Festkultur, S. 10-24.

DÚLMEN, Richard van, Historische Anthropologie in der deutschen Sozialgeschichtsschreibung, in: GWU 42 (1991) S. 692-709.

DYOS, Harold J., Greater and greater London: metropolis and provinces in the nineteenth and twentieth centuries, in: David CanNaDINE, David REEDER $(\mathrm{Hg}$.), Harold J. Dyos: Exploring the urban past. Essays in urban history, Cambridge u.a. 1982, S. 37-55.

DZELZAINIS, Martin, Charles I and tyranny, in: CoRNs ( $\mathrm{Hg}$.), The royal image, S. 74-95.

ECHTERNKAMP, Jörg, Sven Oliver MÜLlER, Perspektiven einer politik- und kulturgeschichtlichen Nationalismusforschung. Einleitung, in: DIES. (Hg.), Die Politik der Nation. Deutscher Nationalismus in Krieg und Krisen, 1760-1960, München 2002 (Beiträge zur Militärgeschichte, S. 56), S. 1-24.

EDGERTON, Robert B., Death or glory. The legacy of the Crimean War, Boulder/Colorado, Oxford 1999.

EINHOLZ, Sibylle, Was der Nachwelt bleibt - Einblicke in die Berliner Sepulchralplastik, in BLOCH, vON SIMSON, DIES. (Hg.), Ethos und Pathos, S. 257-280. 
EISENBERG, Christiane, Arbeiter, Bürger und der »bürgerliche Verein« 1820-1870. Deutschland und England im Vergleich, in: KOCKA (Hg.), Bürgertum im 19. Jahrhundert, S. 187-219.

EISENSTADT, Shmuel Noah, Die Konstruktion nationaler Identitäten in vergleichender Perspektive, in: GIESEN (Hg.), Nationale und kollektive Identität, S. 21-38.

ElEY, Geoff, Nations, Publics, and Political Cultures, in: Craig J. Calhoun u.a. (Hg.), Habermas and the public sphere, Cambridge/Mass. 1992, S. 289-339.

ELSNER, Tobias von, Kaisertage. Die Hamburger und das Wilhelminische Deutschland im Spiegel öffentlicher Festkultur, Frankfurt a. M. u.a. 1991 (Europäische Hochschulschriften Reihe 3, 471).

ENDLICH, Stefanie, Die Neue Wache 1818-1993. Stationen eines Bauwerks, in: Gert MATTENKLOTT (Red.), Deutsche Nationaldenkmale, S. 101-113.

—, Bernd WURLITZER, Skulpturen und Denkmäler in Berlin, Berlin 1990.

ENGEL, Helmut, Die Denkmäler- und Geschichtslandschaft der Mitte Berlins, in: DERS., RIBBE (Hg.), Hauptstadt Berlin, S. 81-87.

-, »Durch sie ist die Gestalt der Dinge verändert und die Hoffnung auf eine bessere $\mathrm{Zu}$ kunft begründet worden« - oder: Der Beginn der "Via triumphalis «, in: DERS., RIBBE (Hg.), Via triumphalis, S. 31-46.

-, Der Berliner Dom im 19. Jahrhundert, in: Detlef PLOSE (Red.), Der Berliner Dom, S. 22-35.

-, Wolfgang RIBBE (Hg.), Hauptstadt Berlin - wohin mit der Mitte?: Historische, städtebauliche und architektonische Wurzeln des Stadtzentrums, Berlin 1993.

-, Wolfgang RIBBE (Hg.), Via triumphalis. Geschichtslandschaft »Unter den Linden« zwischen Friedrich-Denkmal und Schloßbrücke, Berlin 1997.

ENGEL, Martin, Fragen zur Entstehungs- und Bedeutungsgeschichte des Forum Friderizianum, in: ENGEL, RIBBE (Hg.), Hauptstadt Berlin, S. 89-99.

ENGLUND, Steven, The Ghost of Nation Past, in: JMH 64 (1992) S. 299-320.

EPSTEIN, James A., Understanding the cap of liberty: symbolic practice and social conflict in early nineteenth-century England, in: P\&P 122 (1989) S. 75-118.

-, Spatial practices/democratic vistas, in: SocH 24 (1999) S. 294-320.

ERBE, Michael, Berlin als Brennpunkt der Politik, in: RIBBE (Hg.), Geschichte Berlins, Bd. 2, S. 755-777.

-, (Hg.) Berlinische Lebensbilder, Bd. 4: Geisteswissenschaftler, Berlin 1989 (Einzelveröffentlichungen der Historischen Kommission zu Berlin, 60).

ERLANDE-BRANDENBURG, Alain, Notre-Dame de Paris, in: NORA, Les Lieux III, Bd. 3, S. 358-402.

ESPAGNE, Michel, Les transferts culturels franco-allemands, Paris 1999 (Perspectives germaniques).

ETLIN, Richard A., Symbolic space. French enlightenment architecture and its legacy, Chicago, London 1994.

EVANS, Eric, Englishness and Britishness. National identities, c.1790-c.1870, in: GRANT, STRNGER (Hg.), Uniting the Kingdom, S. 223-243.

FADEN, Eberhard, Zur politischen Geschichte der Berliner Denkmäler, in: Zeitschrift des Vereins für die Geschichte Berlins 54 (1937) S. 91-96.

FAIRBANKS, Jonathan L., Eternal Celebration in American Memorials, in: REYNOLDS (Hg.), "Remove not the ancient landmark «, S. 161-189.

FAULENBACH, Bernd, Die Reichsgründungsepoche als formative Phase des deutschen "Sonderwegs «? Zu Hans-Ulrich Wehlers "Deutscher Gesellschaftsgeschichte", in: AfS 38 (1998) S. 368-384.

FEHRENBACH, Elisabeth, Wandlungen des deutschen Kaisergedankens (1871-1918), München, Wien 1969 (Studien zur Geschichte des 19. Jahrhunderts, 1). 
—, Über die Bedeutung der politischen Symbole im Nationalstaat, in: HZ 213 (1971) S. 296-357.

-, Verfassungsstaat und Nationsbildung 1815-1871, München 1992 (Enzyklopädie deutscher Geschichte, 22).

FELDMAN, David, Gareth STEDMAN JONES, Introduction, in: DIES. (Hg.), Metropolis London. Histories and representations since 1800, London, New York 1989

FÉLIX, Maurice, Le régime administratif et financier de la Ville de Paris et du Département de la Seine, 3 Bände, Paris o.J.

FEUCHTWANGER, Edgar J.: Democracy and Empire. Britain 1865-1914, London 1985, ${ }^{10} 1998$ (The New History of England, 9).

FIERRO, Alfred, Histoire et dictionnaire de Paris, Paris 1996.

FINN, Margot, "A vent which has conveyed our principles«: English Radical Patriotism in the Aftermath of 1848, in: JMH 64 (1992) S. 637-659.

FTSCHER, Heike, Tannenberg-Denkmal und Hindenburgkult. Hintergründe eines Mythos, in: Michael HưTT u.a. (Hg.), Unglücklich das Land, das Helden nötig hat. Leiden und Sterben in den Kriegsdenkmälern des Ersten und Zweiten Weltkrieges, Marburg 1990 (Studien zur Kunst- und Kulturgeschichte, 8), S. 28-49.

FISCHER, Heinz-Dietrich, Handbuch der politischen Presse in Deutschland 1480-1908: Synopse rechtlicher, struktureller und wirtschaftlicher Grundlagen der Tendenzpublizistik im Kommunikationsfeld, Düsseldorf 1981.

- $(\mathrm{Hg}$.), Deutsche Zeitungen des 17. bis 20. Jahrhunderts, Pullach bei München 1972.

FLECKNER, Uwe, Le retour des cendres de Napoléon. Vergängliche Denkmäler zur Domestizierung einer Legende, in: DIERS (Hg.), Mo(nu)mente, S. 61-76.

FOLLMER, Moritz, Die Verteidigung der bürgerlichen Nation. Industrielle und hohe Beamte in Deutschland und Frankreich 1900-1930 (Kritische Studien zur Geschichtswissenschaft, 154), Göttingen 2002.

FOERSTER, Roland G. (Hg.), Die Wehrpflicht. Entstehung, Erscheinungsformen und politisch-militärische Wirkung, München 1994 (Beiträge zur Militärgeschichte, 43).

FRANÇOIS, Étienne, M. Rainer LEPSIUS, Nation und Nationalismus in Deutschland, in: Heinrich A. WINKLER (Hg.), Nationalismus in der Welt von heute, Göttingen 1982 (GG Sonderheft 8), S. 12-27.

-, Rolf REICHARDT, Les formes de sociabilité en France du milieu du XVIII siècle au milieu du XIX siècle, in: RHMC 34 (1987) S. 453-472.

-, Hannes SIEGRIST, Jakob VoGEL (Hg.), Nation und Emotion. Deutschland und Frankreich im Vergleich. 19. und 20. Jahrhundert, Göttingen 1995 (Kritische Studien zur Geschichtswissenschaft, 110).

-, Die Nation. Vorstellungen, Inszenierungen, Emotionen, in: DIES. (Hg.), Nation und Emotion, S. 13-35.

-, Hagen SCHULZE (Hg.), Deutsche Erinnerungsorte, 3 Bände, München 2001.

-, Einleitung, in: DIES. (Hg.), Deutsche Erinnerungsorte, 1, S. 9-24.

FRETTAG, Sabine, Friedrich Hecker. Biographie eines Republikaners, Stuttgart 1998 (Transatlantische Historische Studien, 10).

FREVERT, Ute, Nation, Krieg und Geschlecht im 19. Jahrhundert, in: HETTLING, NOLTE (Hg.), Nation und Gesellschaft in Deutschland, S. 151-170.

-, Die kasernierte Nation. Militärdienst und Zivilgesellschaft in Deutschland, München 2001.

FREY, Manuel, Tugendspiele. Zur Bedeutung der "Tableaux vivants" in der bürgerlichen Gesellschaft des 19. Jahrhunderts, in: Historische Anthropologie 6 (1998) S. 401-430.

FRIEDEMANN, Peter, Tendenzen und Ergebnisse von neueren Forschungen zur Geschichte der Pariser Kommune, in: AfS 39 (1999) S. 494-501. 
FRIEDMAN, Terry F., Foggini's statue of Queen Anne, in: Klaus LANKHEIT (Hg.), Kunst des Barock in der Toskana. Studien zur Kunst unter den letzten Medici, München 1976, S. 39-56.

FRIJHOFF, Willem, La ville: lieu de mémoire de l'Europe moderne?, in: DEN BOER, DERS. (Hg.), Lieux de mémoire, S. 61-77.

FUCHS, Eckhardt, Das Deutsche Reich auf den Weltausstellungen vor dem Ersten Weltkrieg, in: Comparativ 9 (1999) S. 61-88.

FURET, François, Mona Ozouf (Hg.), Dictionnaire critique de la Révolution Française, Paris 1988.

GaEHTGENS, Thomas W., Napoleons Arc de Triomphe, Göttingen 1974 (Abhandlungen der Akademie der Wissenschaften in Göttingen, Philologisch-Historische Klasse, 3. Folge, Nr. 90).

GALL, Lothar, Die Deutschen und Bismarck, in: Ralph MELVLLE u.a. (Hg.), Deutschland und Europa in der Neuzeit, FS fur Karl Otmar von Aretin zum 65. Geburtstag, Wiesbaden, Stuttgart 1988 (Veröffentlichungen des Instituts für Europäische Geschichte Mainz. Abt. Universalgeschichte, 134/2), S. 525-536.

-, Berlin als Zentrum des deutschen Nationalstaates, in: RIBBE, SCHMÄDEKE, Berlin, S. 229-238.

-, Die Germania als Symbol nationaler Identität im 19. und 20. Jahrhundert, Göttingen 1993 (Nachrichten der Akademie der Wissenschaften in Göttingen, I. Philologischhistorische Klasse Nr. 2).

-, Germania. Eine deutsche Marianne? Une Marianne allemande?, Bonn 1993 (Reflexions sur l'Allemagne au $20^{\circ}$ siècle. Reflexionen über Deutschland im 20. Jahrhundert).

-, Gegenwart und Mythos in Richard Wagners »Ring«, in: DERS., Bürgertum, liberale Bewegung und Nation. Ausgewählte Aufsätze, München 1996, S. 362-372.

-, Das Argument der Geschichte. Überlegungen zum gegenwärtigen Stand der Geschichtswissenschaft, in: HZ 264 (1997) S. 1-20.

—, Europa auf dem Weg in die Moderne 1850-1890, München ${ }^{3} 1997$ (Oldenbourg Grundriß der Geschichte, 14).

GANDERT, Klaus-Dietrich, Vom Prinzenpalais zur Humboldt-Universität. Die historische Entwicklung des Universitätsgebäudes in Berlin mit seinen Gartenanlagen und Denkmälern, Berlin (Ost) 1985.

GARSON, Jules, L'évolution napoléonienne de Victor Hugo sous la Restauration, Paris 1900.

GASNIER, Thierry, Les héros de l'histoire locale au XIX $\mathrm{X}^{e}$ siècle en France, in: DEN BOER, FRIJHOFF (Hg.), Lieux de mémoire, S. 219-225.

GEARY, Dick, Working-class identities in Europe, 1850-1914, in: Mary FULBROOK (Hg.), National histories and European history, London 1993, S. 204-215.

GEERTZ, Clifford, Thick description: towards an interpretative theory of culture, in: DERS., The Interpretation of cultures, selected essays, New York 1973, ${ }^{27} 1994$, S. 3-30.

GELLNER, Ernest, Nations and Nationalism, Oxford 1983, ND 1990.

GEORGE, Jocelyne, Jean-Yves MOLLIER, La plus longue des Républiques, 1870-1940, Paris 1994.

GEORGEL, Chantal, 1848. La République et l'art vivant, Paris 1998.

GERHARD, Ute, Jürgen LINK, Zum Anteil der Kollektivsymbolik an den Nationalstereotypen, in: LINK, WULFING (Hg.), Nationale Mythen und Symbole, S. 16-52.

GERSMANN, Gudrun, Der Streit um die Straßennamen. Städtische Gedenkpolitik zwischen Französischer Revolution und III. Republik, in: DIES., KOHLE (Hg.), Frankreich 18481870. Die Französische Revolution in der Erinnerungskultur des Zweiten Kaiserreiches, Stuttgart 1998, S. 43-57.

GERSON, Stéphane, Town, nation or humanity? Festive delineations of place and past in northern France, ca. 1825-1865, in: JMH 72 (2000) S. 628-682. 
GEYER, Albert, Geschichte des Schlosses zu Berlin, Bd. 2: Vom Königsschloß zum SchloB des Kaisers (1698-1918), bearb. v. Sepp-Gustav GROSCHEL, Berlin ${ }^{2} 1993$.

GBSON, Ralph, The intensification of national consciousness in modern Europe, in: Claus BJøRN, Alexander GRANT, Keith J. STRINGER (Hg.), Nations, nationalism and patriotism in the European Past, Kopenhagen 1994, S. 177-188.

GIDDINGS, Robert, Delusive seduction, pride, pomp, circumstance and military music, in: MAcKENZIE (Hg.), Popular Imperialism, S. 25-49.

GESEN, Bernhard (Hg.), Nationale und kulturelle Identität: Studien zur Entwicklung des kollektiven Bewußtseins in der Neuzeit, Frankfurt a. M. 1991.

GLCHER-HOLTEY, Ingrid, Kulturelle und symbolische Praktiken: das Unternehmen Pierre Bourdieu, in: HARDTWIG, WEHLER (Hg.), Kulturgeschichte Heute, S. 111-130.

-, Plädoyer für eine dynamische Mentalitätsgeschichte, in: GG 24 (1998) S. 476-497.

GLDEA, Robert, The Past in French History, New Haven, London 1994.

GRARDET, Raoul, L'idée coloniale en France de 1871 à 1962, Paris 1972.

-, Mythes et mythologies politiques, Paris 1986.

—, Le nationalisme français. Anthologie 1871-1914, Paris 1983, ${ }^{2} 1992$, S. 12-20.

GIRAULT, René, Guerres et sentiment national au XIX ${ }^{e}$ siècle, in: RHMC, Suppl. 43 (1996) S. 14-21.

GIROUARD, Mark, The Return of Lancelot. Chivalry and the english gentleman, New Haven, London 1981.

GODECHOT, Jacques, Napoléon: pour ou contre?, in: DERS., L'Europe et l'Amérique à l'époque napoléonienne (1800-1815), Paris 1967, S. 263-292.

GOSCHLER, Constantin, Wissenschaftliche "Vereinsmenschen«. Wissenschaftliche Vereine in Berlin im Spannungsfeld von Wissenschaft und Offentlichkeit, 1870-1900, in: DERS. (Hg.), Wissenschaft und Offentlichkeit in Berlin, 1870-1930, Stuttgart 2000, S. 31-63.

GoUlEMOT, Jean-Marie, Éric WALTER, Les centenaires de Voltaire et de Rousseau. Les deux lampions des Lumières, in: NORA (Hg.), Les lieux I, S. 381-420.

GRAMACCINI, Gisela, Sur le projet d'élever un monument en l'honneur de Rousseau, in: [Galeries Nationales du Grand Palais:] La Révolution Française et l'Europe 1789-1799, Bd. 3, Paris 1989, S. 893-902.

GRANT, Alexander, Keith J. STRINGER (Hg.), Uniting the Kingdom? The making of British History, London 1995.

GREDER, L., Le »Nu Héroïque« à Montmartre. La statue de Napoléon au Square Vintimille, in: Bulletin de la Société d'Histoire et d'Archéologie des $\mathrm{LX}^{\mathrm{e}}$ et XVII ${ }^{\mathrm{c}}$ arrondissements, Le Vieux Montmartre, IV $V^{e}$ série, Bd. 3 (années 1901-1905), Paris 1906, S. 234-5.

GREENFELD, Liah, Nationalism. Five Roads to Modernity, Cambridge/Mass. 1992, ND 1994.

-, Is Nation unavoidable? Is Nation unavoidable today?, in: Hanspeter KRIESI u.a. (Hg.), Nation and National Identity. The European experience in perspective, Zürich 1999, S. 37-53.

GRIMM, Reinhold, Jost HERMAND (Hg.), Deutsche Feiern, Wiesbaden 1977 (Athenaion Literaturwissenschaft, 5).

GROBE-KRACHT, Klaus, Gedächtnis und Geschichte: Maurice Halbwachs - Pierre Nora, in: GWU 47 (1996) S. 21-31.

GROUD, Guénola, Daniel IMBERT (Hg.), Quand Paris dansait avec Marianne, 1879-1889, Paris 1989 (AK).

HAACKE, Wilmont, Günter PöTTER, Die Politische Zeitschrift 1665-1965, Bd. 2: 19001980, Stuttgart 1982.

HAAN, Heiner, Gottfried NIEDHART, Geschichte Englands vom 16. bis zum 18. Jahrhundert, München 1993. 
HAAS, Hanns, Hannes STEKL, Einleitung, in: DIES. (Hg.), Bürgerliche Selbstdarstellung: Städtebau, Architektur, Denkmäler, Wien, Köln, Weimar 1995 (Bürgertum in der Habsburgermonarchie, 4), S. 9-22.

HABERMAS, Jürgen, Strukturwandel der Öffentlichkeit. Untersuchungen zu einer Kategorie der bürgerlichen Gesellschaft, Frankfurt a.M ${ }^{3} 1993$.

HACHTMANN, Rüdiger, Berlin 1848. Eine Politik- und Gesellschaftsgeschichte der Revolution, Bonn 1997 (Veröffentlichungen des Instituts für Sozialgeschichte e.V., Braunschweig, Bonn).

HAGEMANN, Karen, "Deutsche Heldinnen«: Patriotisch-nationales Frauenhandeln in der Zeit der antinapoleonischen Kriege, in: PLANERT (Hg.), Nation, Politik und Geschlecht, S. 86-112.

HALBWACHS, Maurice, Das Gedächtnis und seine sozialen Bedingungen, Frankfurt a. M 1985 [frz.: Les cadres sociaux de la mémoire, Paris 1976].

—, Das kollektive Gedächtnis, Frankfurt a. M. 1985.

HÁLFDANARSON, Gudmundur, lingvellir. An icelandic »Lieu de mémoire«, in: History and Memory 12 (2000) S. 5-29.

Hall, Catherine, Keith MCClelland, Jane Rendall (Hg.), Defining the Victorian nation. Class, race, gender and the British Reform Act of 1867, Cambridge 2000.

HALTERN, Utz, Krone und Palast. Zur politischen Metaphorik des Bürgertums, in: AKG 82 (2000) S. 121-155.

HAMILTON, C. I., Naval hagiography and the Victorian Hero, in: HJ 23 (1980) S. 381-398.

HAMMER, Klaus, Historische Friedhöfe und Grabmäler in Berlin, Berlin 1994.

HANDLEY-READ, Lavinia, Whitehall Sculpture, in: Architectural Review 128 (1970) S. 276-279.

HANISCH, Manfred, Nationalisierung der Dynastien oder Monarchisierung der Nation? Zum Verhältnis von Monarchie und Nation in Deutschland im 19. Jahrhundert, in: BIRKE, KETTENACKER (Hg.), Bürgertum, Adel und Monarchie, S. 71-91.

HANNA, Martha, Iconology and ideology: Images of Joan of Arc in the Idiom of the Action Française, 1908-1931, in: FrenchHSt 14 (1985/86) S. 215-239.

HARDMAN, Malcolm, Six Victorian Thinkers, Manchester 1991.

HARDTWG, Wolfgang, Bürgertum, Staatssymbolik und Staatsbewußtsein im Deutschen Kaiserreich 1871-1914, in: GG 16 (1990) S. 269-295.

-, Erinnerung, Wissenschaft, Mythos. Nationale Geschichtsbilder und politische Symbole in der Reichsgründungsära und im Kaiserreich, in: DERS., Geschichtskultur, S. 224-263.

-, Nationsbildung und politische Mentalität. Denkmal und Fest im Kaiserreich, in: DERS., Geschichtskultur, S. 264-301.

—, Geschichtskultur und Wissenschaft, München 1990.

-, Soziale Räume und politische Herrschaft. Leistungsverwaltung, Stadterweiterung und Architektur in München 1871 bis 1914, in: DERS., Klaus TENFELDE (Hg.), Soziale Räume in der Urbanisierung. Studien zur Geschichte Münchens im Vergleich 1850-1933, München 1990, S. 59-153.

-, Nationsbildung und Hauptstadtfrage. Berlin in der deutschen Revolution 1848/49, in: DERS., Nationalismus und Bürgerkultur in Deutschland 1500-1914: Ausgewählte Aufsätze, Göttingen 1994, S. 149-164.

-, Nation - Region - Stadt. Strukturmerkmale des deutschen Nationalismus und lokale Denkmalkulturen, in: Gunther MAI (Hg.), Das Kyffhäuser-Denkmal 1896-1996. Ein nationales Monument im europäischen Kontext, Köln, Weimar, Wien 1997, S. 53-83.

-, Hans-Ulrich WEHLER (Hg.), Kulturgeschichte Heute (GG Sonderheft, 16), Göttingen 1996.

HARgROVE, June, Les statues de Paris, in: NORA (Hg.), Les lieux II. La Nation, Bd. 3, S. 243-282. 
-, Les statues de Paris. La représentation des grands hommes dans les rues et sur les places de Paris, Anvers 1989.

-, Shaping the national image: The cult of statues to Great Men in the Third Republic, in: Richard A. ETLIN (Hg.), Nationalism and the Visual Arts, Hanover, London 1991 (Studies in the History of Art, 13), S. 49-63.

HARRIS, Michael, London's Local Newspapers: patterns of change in the Victorian Period, in: BRAKE, JONES, MADDEN (Hg.), Investigating Victorian Joumalism, S. 104-1 19.

HARTOG, François, Temps et histoire. „Comment écrire l'histoire de France?«, in: Annales 50 (1995) S. 1219-1236.

HARTWEG, Frédéderic, Die Hugenotten in Berlin: Eine Geschichte, die vor 300 Jahren begann ..., in: DERS., JERSCH-WENZEL (Hg.), Die Hugenotten und das Refuge, S. 1-56.

-, Stefi JERSCH-WENZEL (Hg.), Die Hugenotten und das Refuge: Deutschland und Europa, Berlin 1990 (Einzelveröffentlichungen der Historischen Kommission zu Berlin, 74).

HARTWIG, Helmut, Karl RIHA, Politische Ästhetik und Öffentlichkeit. 1848 im Spaltungsprozeß des historischen Bewußtseins, Fernwald-Steinbach, Wismar 1974.

HASKELL, Francis, History and its images: Art and the interpretation of the past, New Haven, London 1993, ND 1998 [dt.: Die Geschichte und ihre Bilder: Die Kunst und die Deutung der Vergangenheit, München 1995].

HASTINGS, Adrian, The construction of nationhood. Ethnicity, religion and nationalism, Cambridge 1997.

HAUPT, Heinz-Gerhard, Die Konstruktion der Regionen und die Vielfalt der Loyalitäten im Frankreich des 19. und 20. Jahrhunderts, in: LOTTES (Hg.), Region, S. 121-126.

-, Der Nationalismus in der neueren deutschen und französischen Geschichtswissenschaft, in: FRANÇOIS u.a. (Hg.), Nation und Emotion, S. 39-55.

-, Jürgen KOCKA, Historischer Vergleich: Methoden, Aufgaben, Probleme. Eine Einleitung, in: DIES. (Hg.), Geschichte und Vergleich. Ansätze und Ergebnisse international vergleichender Geschichtsschreibung, Frankfurt a. M., New York 1996, S. 9-45.

-, Charlotte TACKE, Die Kultur des Nationalen. Sozial- und kulturgeschichtliche Ansätze bei der Erforschung des europäischen Nationalismus im 19. und 20. Jahrhundert, in: HARDTWIG, WEHLER (Hg.), Kulturgeschichte heute, S. 255-283.

-, Dieter LANGEWIESCHE (Hg.), Nation und Religion in der deutschen Geschichte, Frankfurt, New York 200I.

HEARDER, Harry, Europe in the nineteenth century 1830-1880 (A general History of Europe), Burnt Mill, Harlow ${ }^{2} 1988$.

HEDINGER, Hans-Walter, Der Bismarck-Kult, in: Gunther STEPHENSON (Hg.), Der Religionswandel unserer Zeit im Spiegel der Religionswissenschaft, Darmstadt 1976, S. 201215.

-, Bismarck-Denkmäler und Bismarck-Verehrung, in: MAI, WAETZOLDT (Hg.), Kunstverwaltung, S. 277-314.

HEFFTER, Heinrich, Die deutsche Selbstverwaltung im 19. Jahrhundert. Geschichte der Ideen und Institutionen, Stuttgart ${ }^{2} 1969$.

HEIMANN, Nora H., The art of politics in early nineteenth century France: E.É.F. Gois's wJeanne d'Arc pendant le combat « as metaphor, in: GBA 140 (1998) S. 29-46.

HERBERT, Robert L., David, Voltaire, Brutus and the French Revolution: an essay in art and politics, London 1972.

HERVE, Robert, Urbanisme et culte du grand homme au XIX ${ }^{c}$ siècle: le destin de la statue équestre du Duc d'Orléans par Marochetti, in: Bulletin de la Société de l'Histoire de Paris et de l'île de France 117 (1990) S. 295-311.

HERZIG, Arno, Die Lassalle-Feiern in der politischen Festkultur der frühen deutschen Arbeiterbewegung, in: DUDING, FRIEDEMANN, MUNCH (Hg.), Öffentliche Festkultur, S. 321-333. 
HESS, Günter, Allegorie und Historismus. Zum »Bildgedächtnis« des späten 19. Jahrhunderts, in: Hans FrOMM, Wolfgang HARMS, Uwe RUBERG (Hg.), Verbum et Signum, Bd. l: Beiträge zur mediävistischen Bedeutungsforschung, München 1975, S. 555-591.

HETTLING, Manfred, Das Begräbnis der Märzgefallenen 1848 in Berlin, in: DERS., NOLTE (Hg.), Bürgerliche Feste, S. 95-123.

—, Bürger oder Soldaten? Kriegerdenkmäler 1848 bis 1854, in: JEISMANN, KOSELLECK (Hg.), Der politische Totenkult, S. 147-193.

—, Erlebnisraum und Ritual. Die Geschichte des 18. März 1848 im Jahrhundert bis 1948, in: HA 5 (1997) S. 417-434.

-, »Wehmütig und freudig«, Die Totenfeiem für Robert Blum, in: DERS., Totenkult statt Revolution. 1848 und seine Opfer, Frankfurt a.M. 1998, S. 52-75.

—, Politische Bürgerlichkeit. Der Bürger zwischen Individualität und Vergesellschaftung in Deutschland und der Schweiz von 1860-1918, Göttingen 1999 (Bürgertum, 13).

-, Die Jagd nach dem demokratischen Anfang. Rückblick auf das Jubiläumsjahr zu 1848, in: GWU 51 (2000) S. 302-312.

—, Paul NOLTE (Hg.), Bürgerliche Feste. Symbolische Formen politischen Handelns im 19. Jahrhundert, Göttingen 1993

-, Paul NOLTE, Bürgerliche Feste als symbolische Politik im 19. Jahrhundert, in: DIES. (Hg.), Bürgerliche Feste, S. 7-36.

HICHBERGER, Joan W. M., Images of the army. The military in british art 1815-1914, Manchester 1988.

HILL, Christopher, God's Englishman: Oliver Cromwell and the English Revolution; London 1970, New York ${ }^{16} 1988$.

-, The Norman Yoke, in: DERS., Puritanism and revolution. Studies in interpretation of the English revolution of the $17^{\text {th }}$ century, London 1958, ND 1995, S. 50-122.

HILTON, Boyd, The age of atonement. The influence of Evangelicalism on social and economic thought, 1795-1865, Oxford 1988, ND 1991.

HINTZE, Otto, Soziologische und geschichtliche Staatsauffassung. Zu Franz Oppenheimers System der Soziologie, in: DERS., Soziologie und Geschichte. Gesammelte Abhandlungen zur Soziologie, Politik und Theorie der Geschichte, 3 Bände, Göttingen 1962-1967, hier Bd. 2 (1964).

HIRSCHHAUSEN, Ulrike von, Jöm LEONHARD ( $\mathrm{Hg}$.), Nationalismen in Europa. West- und Osteuropa im Vergleich, Göttingen 2001.

HoBHOUSE, Hermione, The Monarchy and the Middle Classes: The role of Prince Albert, in: BIRKE, KETTENACKER (Hg.), Bürgertum, Adel und Monarchie, S. 53-69.

-, Prinz Albert und die Weltausstellung von 1851, in: Wilfried ROGASCH (Hg.), Victoria and Albert. Vicky \& the Kaiser. Ein Kapitel deutsch-englischer Familiengeschichte, Ostfildern-Ruit 1997 (AK Berlin), S. 87-97.

HOBSBAWM, Eric John, Die englische middle class 1780-1920, in: KOCKA (Hg.), Bürgertum im 19. Jahrhundert, Bd. 1, S. 79-106.

-, Nations and Nationalism since 1780. Programme, myth, reality, Cambridge 1990, ${ }^{2} 1997$.

-, Mass-producing Traditions: Europe, 1870-1914, in: DERS., RANGER (Hg.), The invention of tradition, S. 263-307.

-, Terence RANGER (Hg.), The invention of tradition, Cambridge 1983, ND 2000.

HÖLSCHER, Lucian, Geschichte und Vergessen, in: HZ 249 (1989) S. 1-17.

HOLSTEN, Siegmar, Allegorische Darstellungen des Krieges 1870-1918. Ikonologische und ideologiekritische Studien, München 1976 (Studien zur Kunst des 19. Jahrhunderts, 27).

HOMANS, Margaret, Royal representations. Queen Victoria and British Culture, 1837 1876, Chicago, London 1998.

-, Adrienne MUNICH (Hg.), Remaking Queen Victoria, Cambridge 1997 (Cambridge studies in nineteenth century literature and culture, 10). 
HOPPE, Marie-Nicolette, Beiträge zum Scharnhorst-Bild im 19. Jahrhundert (1813-1871). Persönlichkeit und Werk in der frühen Rezeption, Bonn 1995.

HOPPEN, Karl T., The Mid-Victorian Generation, 1846-1886, Oxford 1998 (New Oxford History of England).

HORN, David G., Reading History: Towards a Comparative Cultural Studies. A review Article, in: CSSH 39 (1997) S. 734-741.

HU'BINGER, Gangolf, Kulturprotestantismus und Politik. Zum Verhältnis von Liberalismus und Protestantismus im wilhelminischen Deutschland, Tübingen 1994.

HƯSER, Dietmar, Bauern und Franzosen, Integration und Eigensinn. Zur ländlichen Politisierung und kulturellen Nationsbildung im Frankreich des 19. Jahrhunderts, in: AfS 41 (2001) S. 409-431.

HUGGER, Paul (Hg.), Stadt und Fest. Zu Geschichte und Gegenwart europäischer Festkultur. Unterägeri, Stuttgart 1987.

HUNT, Lynn, Politics, culture, and class in the French Revolution, Berkeley, Los Angeles, London 1984 [dt.: Symbole der Macht, Macht der Symbole. Die Französische Revolution und der Entwurf einer politischen Kultur, Frankfurt 1989]

HUTTER, Peter, »Die feinste Barbarei«. Das Völkerschlachtdenkmal bei Leipzig, Mainz 1990.

HUTTON, Patrick H., History as an Art of Memory, Hanover, London 1993.

IHL, Olivier, Des fêtes sans Dieu. L'enjeu de laïcité dans les célébrations républicaines de la Troisième République, in: DEN BOER, FRIJOFF (Hg.), Lieux de mémoire, S. 227-235.

- La fête républicaine, Paris 1996.

INGENLATH, Markus, Mentale Aufrüstung. Militarisierungstendenzen in Frankreich und Deutschland vor dem Ersten Weltkrieg, Frankfurt a. M, New York 1998.

INWOOD, Stephen, A history of London, Basingstoke, Oxford 2000.

IRVINE, William D., Royalists and the politics of nationalism, in: TOMBS (Hg.), Nationhood, S. 108-120.

JAHR, Christoph, Uwe MAI, Kathrin RoLlER (Hg.), Feindbilder in der deutschen Geschichte. Studien zur Vorurteilsgeschichte im 19. und 20. Jahrhundert, Berlin 1994 (Zentrum für Antisemitismusforschung der Technischen Universität Berlin, 10).

JANSEN, Christian, Einheit, Macht und Freiheit. Die Paulskirchenlinke und die deutsche Politik in der nachrevolutionären Epoche 1849-1867, Düsseldorf 2000.

JaNZ, Oliver, Probleme und Perspektiven des historischen Gesellschaftsvergleichs, in: Comparativ 5 (1995) S. 135-155.

JARDANOVA, Ludmilla, Science and nationhood: cultures of imagined communities, in: CUBITT (Hg.), Imagining nations, S. 192-211.

JAY, Robert Allen, Art and nationalism in France 1870-1914, Ann Arbor 1979.

JEISMANN, Michael, Was bedeuten Stereotypen für nationale Identität und politisches Handeln?, in: LINK, WÜLFING (Hg.), Nationale Mythen und Symbole, S. 84-93.

-, Das Vaterland der Feinde. Studien zum nationalen Feindbegriff und Selbstverständnis in Deutschland und Frankreich 1792-1918, Stuttgart 1992 (Sprache und Geschichte, 19).

-, Rolf WESTHEDER, Wofür stirbt der Bürger? Nationaler Totenkult in Deutschland und Frankreich seit der Französischen Revolution, in: DERS., KoSELLECK (Hg.), Der politische Totenkult, S. 23-50.

-, Reinhart KoSELlECK (Hg.), Der politische Totenkult, Kriegerdenkmäler in der Moderne, München 1994.

JERSCH-WENZEL, Stefi, Toleranz und Ökonomie im 18. Jahrhundert, in: HARTWEG, DIES. (Hg.), Die Hugenotten und das Refuge, S. 147-157.

-, Barbara JOHN (Hg.), Von Zuwanderern zu Einheimischen. Hugenotten, Juden, Böhmen, Polen in Berlin, Berlin 1990.

JOHNSON, Douglas H., The death of Gordon: A Victorian Myth, in: Journal of Imperial and Commonwealth History 10 (1982) S. 285-310. 
JOHNSTON, Otto W., Der deutsche Nationalmythos. Ursprung eines politischen Programms, Stuttgart 1990.

JOLY, Bertrand, Déroulède: L'inventeur du nationalisme français, Paris 1998.

JONAS, Raymond A., Monument as Ex-Voto, Monument as Historiography: The Basilica of Sacré-Cour, in: FrenchHSt 18 (1993) S. 482-502.

JONES, Gareth Stedman, The language of Chartism, in: James EPSTEIN, Dorothy THOMPSON (Hg.), The Chartist Experience: Studies in Working-class radicalism and culture, 1830-60, London, Basingstoke 1982, S. 3-58.

-, Working-class culture and working-class politics in London 1870-1900: Notes on the remaking of a working class, in: DERS., Languages of class. Studies in English working class history, 1832-1982, Cambridge 1983, S. 179-238.

JORDAN, David, Die Neuerschaffung von Paris. Baron Haussmann und seine Stadt, Frankfurt 1996 [engl.: Transforming Paris. The life and labours of Baron Haussmann, 1995].

JOURDAN, Annie, Le culte des grands hommes sous la Révolution: l'invention d'un lieu de mémoire, in: DEN BOER, FRIHOFF (Hg.), Lieux de mémoire, S. 165-183.

-, Les Monuments de la Révolution 1770-1804: une histoire de représentation, Paris 1997.

JOYCE, Patrick, Visions of the people. Industrial England and the question of class 18481914, Cambridge 1991.

KAELBLE, Hartmut, Französisches Bürgertum und deutsches Bürgertum 1870-1914, in: KOCKA (Hg.), Bürgertum im 19. Jahrhundert, Bd. 1, S. 107-140.

-, Nachbarn am Rhein. Entfremdung und Annäherung der französischen und deutschen Gesellschaft seit 1880, München 1991.

-, Der historische Vergleich. Eine Einführung zum 19. und 20. Jahrhundert, Frankfurt a. M. 1999.

KARSTEN, Peter, Patriot-Heroes in England and America. Political Symbolism and Changing values over three centuries, Wisconsin 1978.

KASCHUBA, Wolfgang, Kulturalismus: Kultur statt Gesellschaft?, in: GG 21 (1995) S. 8095.

-, Volk und Nation: Ethnozentrismus in Geschichte und Gegenwart, in: WINKLER, KAELBLE (Hg.), Nationalismus, S. 56-81.

KAUFFMANN, Hans, Berliner Baukunst von Schlüter bis Schinkel, in: JbPK 13 (1976) S. $25-43$.

KELLER, Ulrich, Reitermonumente absolutistischer Fürsten. Staatstheoretische Voraussetzungen und politische Funktionen, München 1971.

KELLEY, Donald R., Something happened: Panofsky and cultural history, in: Irving LAVIN (Hg.), Meaning in the visual arts: views from the outside. A centennial commemoration of Erwin Panofsky, Princeton 1995, S. 113-121.

KENNEDY, Paul M., The Pre-war Right in Britain and Germany, in: DERS., Nicholls (Hg.), Nationalist and racialist movements, S. 1-20.

-, Anthony NicHOLLS (Hg.), Nationalist and racialist movements in Britain and Germany before 1914, London 1981.

KIDD, William, Les monuments aux morts mosellans. De 1871 à nos jours, Metz 1999.

KING, Alex, Memorials of the Great War in Britain: The symbolism and politics of Remembrance, Oxford, New York 1998.

KIRCHBERGER, Ulrike, The German National League in Britain an Ideas of a German Overseas Empire, in: EHQ 29 (1999) S. 451-483.

KLENKE, Dietmar, Zwischen nationalkriegerischem Gemeinschaftsideal und bürgerlichziviler Modernität. Zum Vereinsnationalismus der Sänger, Schützen und Turner im Deutschen Kaiserreich, in: GWU 45 (1994) S. 207-223.

KNOPP, Wermer, Kulisse der Macht im Kaiserreich, in: ENGEL, RIBBE (Hg.), Via triumphalis, S. 47-60. 
-, Die Denkmäler- und Geschichtslandschaft der Mitte Berlins, in: DERS., RIBBE (Hg.), Hauptstadt Berlin, S. 81-87.

$\mathrm{KOCH}$, Ursula E., La presse et son public à Paris et à Berlin (1848/49). Une étude exploratoire, in: MIECK, MÖLLER, Voss (Hg.), Paris und Berlin, S. 19-78.

KOCKA, Jürgen, Bürger und Bürgerlichkeit als Probleme der deutschen Geschichte vom späten 18. zum frühen 19. Jahrhundert, in: DERS. (Hg.), Bürger und Bürgerlichkeit im 19. Jahrhundert, Göttingen 1987, S. 21-63.

- (Hg.), Bürgertum im 19. Jahrhundert. Deutschland im europäischen Vergleich, 3 Bände, München 1988.

-, Sozialgeschichte der neunziger Jahre, in: Die neue Gesellschaft/Frankfurter Hefte 40 (1993) S. 1125-1129.

-, Historische Komparatistik in Deutschland, in: HAUPT, DERS. (Hg.), Geschichte und Vergleich, S. 47-60.

KÖRNER, Axel, Das Lied von einer anderen Welt. Kulturelle Praxis im französischen und deutschen Arbeitermilieu 1840-1890, Frankfurt a. M., New York 1997 (Historische Studien, 22).

KOHN, Hans, The genesis and character of English Nationalism, in: Journal of the History of Ideas 1 (1940) S. 69-94.

-, Die Idee des Nationalismus. Ursprung und Geschichte bis zur Französischen Revolution, Frankfurt a. M. 1962.

KOOPMANN, Helmut, Martina LAUSTER (Hg.), Vormärzliteratur in europäischer Perspektive, Bd. 1: Offentlichkeit und nationale Identität, Bielefeld 1996.

KORFF, Gottfried, Politischer »Heiligenkult« im 19. und 20. Jahrhundert, in: Zeitschrift für Volkskunde 71 (1975) S. 202-220.

-, Beim Anblick der Monumente im Wandel der Zeiten. Ein Beitrag zur Berliner Mentalitätsgeschichte, in: ENGEL, RIBBE, Via triumphalis, S. 197-208.

KoSHAR, Rudy, From monuments to traces. Artifacts of German memory, 1870-1990, Berkeley, Los Angeles, London 2000.

KOSELLECK, Reinhart, Preußen zwischen Reform und Revolution. Allgemeines Landrecht, Verwaltung und soziale Bewegung von 1791 bis 1848, ND München 1989.

-, Einleitung, in: JEISMANN, DERS. (Hg.), Der politische Totenkult, S. 9-20.

-, Kriegerdenkmale als Identitätsstiftungen der Überlebenden, in: Odo MARQUARD, Karlheinz STIERLE (Hg.), Identität, München ${ }^{2} 1996$, (Politik und Hermeneutik, 8), S. 255276.

- Zur politischen Ikonologie des gewaltsamen Todes. Ein deutsch-französischer Vergleich, Basel 1998 (Jakob-Burckhardt-Gespräche auf Castelen, 3).

KRENZLIN, Ulrike, Eisernes Kreuz oder Preußenadler: ja oder nein? Zur Vorgeschichte der Diskussion um die Symbole auf dem Brandenburger Tor, in: ENGEL, RIBBE (Hg.), Hauptstadt Berlin, S. 101-114.

KROLL, Frank-Lothar, Monarchie und Gottesgnadentum in Preußen 1840-1861, in: Peter KRÜGER, Julius H. SCHOEPS (Hg.), Der verkannte Monarch. Friedrich Wilhelm IV. in seiner Zeit, Potsdam 1997, S. 45-70.

KRUMEICH, Gerd, Eine oder mehrere Jeannes?, in: Marieluise CHRISTADLER (Hg.), Deutschland - Frankreich. Alte Klischees - neue Bilder, Duisburg 1981, S. 25-40.

-, Jeanne d'Arc in der Geschichte. Historiographie - Politik - Kultur, Sigmaringen 1989 (Beihefte der Francia, 19).

-, Joan of Arc between right and left, in: TOMBS (Hg.), Nationhood, S. 63-73.

-, Jeanne d'Arc-Kult und politische Religiosität in Frankreich nach 1870, in: Wolfgang SCHIEDER (Hg.), Religion und Gesellschaft im 19. Jahrhundert, Stuttgart 1993 (Industrielle Welt, 54), S. 318-331. 
-, Romantische Sensibilität und politisches Engagement. Die Entdeckung Jeanne d'Arcs im 19. Jahrhundert, in: Gangolf HơBINGER, Jürgen OSTERHAMMEL, Erich PELZER ( $\mathrm{Hg}$.), Universalgeschichte und Nationalgeschichten, Freiburg i. Br. 1994, S. 179-194.

-, Zur Entwicklung der ,nation arméer in Frankreich bis zum Ersten Weltkrieg, in: FOERSTER (Hg.), Die Wehrpflicht, S. 133-145.

KSELMAN, Thomas A., Death and the afterlife in moderm France, Princeton 1993.

KUHLEMANN, Frank-Michael, Mentalitätsgeschichte. Theoretische und methodische Überlegungen am Beispiel der Religion im 19. und 20. Jahrhundert, in: HARDTWIG, WEHLER (Hg.), Kulturgeschichte Heute, S. 182-211.

KUHN, William M., Democratic Royalism. The transformation of the British Monarchy, 1861-1914, Houndmills, Basingstoke 1996

KuTZSCH, Gerhard, Der Staat und die Stadt Berlin, in: Der Bär von Berlin 17 (1968) S. 7 21.

KUZMICS, Helmut, Einleitung. Nationalismus, Nationalstaat und Nationalcharakter in zivilisationstheoretischer Sicht, in: DERS., Reinhard BLOMERT, Anette TREIBEL (Hg.), Transformationen des Wir-Gefühls. Studien zum nationalen Habitus, Frankfurt a.M. 1993, S. 7-41.

LAFRANCHI, Jacques, Statues de Paris. Les statues des Grands Hommes élevées à Paris des lendemains de la Révolution à 1940. Leur insertion dans l'histoire politique, sociale et culturelle. Thèse pour le doctorat du $3^{\text {ième }}$ cycle, Paris 1979, unveröffentlichtes Ms. $<$ Bibliothèque de la Sorbonne, Paris, salle de réserve I 5910, $4^{\circ}>$

LAGOMARSINO, David, Charles J. WOOD (Hg.), The trial of Charles I. A documentary history, Hanover, London 1989.

LAMBACHER, Lothar, Die Standbilder preußischer Feldherren im Bodemuseum: ein Berliner Denkmalensemble des 18. Jahrhunderts und sein Schicksal, Berlin 1990.

LANG, Timothy, The Victorians and the Stuart Heritage, Cambridge 1995.

LANGEWIESCHE, Dieter, »... für Volk und Vaterland kräftig zu würken ...«. Zur politischen und gesellschaftlichen Rolle der Turner zwischen 1811 und 1871, in: Ommo GRUPE (Hg.), Kulturgut oder Körperkult? Sport und Sportwissenschaft im Wandel, Tübingen 1990 (Studium Generale), S. 22-61 [wieder in: DERS., Nation, Nationalismus, Nationalstaat in Deutschland und Europa, München 2000, S. 103-131].

-, Die deutsche Revolution von 1848/49 und die vorrevolutionäre Gesellschaft: Forschungsstand und Forschungsperspektiven. Teil II, in: AfS 31 (1991) S. 331-443.

-, Reich, Nation und Staat in der deutschen Geschichte, in: HZ 254 (1992) S. 341-381.

-, Nationalismus im 19. und 20. Jahrhundert: zwischen Partizipation und Aggression, Bonn, Bad-Godesberg 1994 (Gesprächskreis Geschichte, 6).

-, Nation, Nationalismus, Nationalstaat: Forschungsstand und Forschungsperspektiven, in: Neue Politische Literatur 40 (1995) S. 190-236.

-, Die Revolution von 1848/49 im europäischen Kontext. Bemerkungen zu einer Regionalund Lokalforschung in vergleichender Absicht, in: DERS. (Hg.), Demokratiebewegung und Revolution 1847 bis 1849 . Internationale Aspekte und europäische Verbindungen, Karlsnuhe 1998, S. 185-194.

-, Kulturelle Nationsbildung im Deutschland des 19. Jahrhunderts, in: DERS., Nation, Nationalismus, Nationalstaat in Deutschland und Europa, München 2000, S. 82-102.

-, Staatsbildung und Nationsbildung in Deutschland - ein Sonderweg? Die deutsche Nation im europäischen Vergleich, in: VON HIRSCHHAUSEN, LEONHARD (Hg.), Nationalismen, S. 49-67.

-, Georg SCHMIT (Hg.), Föderative Nation. Deutschlandkonzepte von der Reformation bis zum Ersten Weltkrieg, München 2000.

LANGLAND, Elizabeth, Nation and nationality: Queen Victoria in the developing narrative of Englishness, in: HOMANS, MUNICH (Hg.), Remaking Queen Victoria, S. 13-32. 
LANGLANDS, Rebecca, Britishness or Englishness? The historical problem of national identity in Britain, in: Nations and Nationalism 5 (1999) S. 53-69.

LAUBE, Stefan, Konfessionelle Brüche in der nationalen Heldengalerie - protestantische, katholische und jüdische Erinnerungslandschaften im deutschen Kaiserreich (1871-1918), in: HAUPT, LANGEWIESCHE (Hg.), Nation und Religion, S. 293-332.

LAURENS, Patrick, La figure officielle de la République Française: Monnaies et timbres, in: ChARle u.a. (Hg.), La France démocratique, S. 421-429.

LAVAlle, Denise, Le monument de La Défense et la statuaire du XIX ${ }^{c}$ siècle, in: WEILL (Hg.), La perspective, S. 132-154.

LECOQ, Benoît, Les cercles Parisiens au début de la troisième République: de l'apogée au déclin, in: RHMC 32 (1985) S. 591-616.

LEE, Alan, The structure, ownership and control of the press, 1855-1914, in: BOYCE, CURRAN, Wingate (Hg.), Newspaper History, S. 117-129.

LEES, Lynn, Metropolitan Types. London and Paris compared, in: Harold J. DYOS, Michael WOLFF (Hg.), The Victorian City. Images and realities, Bd. 1, London und Boston 1973, S. 413-428.

LEHMANN, Hartmut, Anmerkungen zur Entmythologisierung der Luthermythen 1883-1983, in: AKG 68 (1986) S. 457-477.

LEHNING, J. R., Gossiping about Gambetta. Contested memories in the early Third Republic, in: FrenchHSt 18 (1993) S. 239-254.

LEITH, James A., Space and Revolution: Projects for monuments, squares and public buildings in France 1789-1799, Montreal u.a. 1991.

LEMOINE, Bertrand, La statue de la Liberté/The statue of Liberty, Brüssel, Lüttich 1986 (Institut Français d'Architecture).

LEMOINE-MOLIMARD, Marie-France, Le décor extérieur du Nouveau Louvre sous $\mathrm{Na}$ poléon III: la série des Hommes illustres, in: Revue du Louvre 28 (1978) S. 374-379.

LEPSIUS, M. Rainer, Nation und Nationalismus in Deutschland, in: Heinrich A. WINKLER (Hg.), Nationalismus in der Welt von heute, Göttingen 1982 (GG Sonderheft 8), S. 1227.

LETERRIER, Anne-Sophie, Les hymnes nationaux euopéens, in: CHARLE u.a. (Hg.), La France démocratique, S. 449-455.

LETHĖVE, Jacques, Une statue malchanceuse. 'La Républiquer de Jean-François Soitoux, in: GBA 105 (1963) S. 229-238.

LINK, Jürgen, Wulf WOLFING (Hg.), Nationale Mythen und Symbole in der zweiten Hälfte des 19. Jahrhunderts. Strukturen und Funktionen von Konzepten nationaler Identität, Stuttgart 1991 (Sprache und Geschichte, 16).

LIPP, Carola, Kulturgeschichte und Gesellschaftsgeschichte - Mißverhältnis oder glückliche Verbindung?, in: Paul NOLTE, Manfred HETTLING (Hg.), Perspektiven der Gesellschaftsgeschichte, München 2000, S. 25-35.

LIPP, Claudia, Protestanten feiern ihre Nation - Die kulturprotestantischen Ursprünge des Sedantages, in: HJb 118 (1998) S. 201-222.

LIPP, Wilfried, Natur - Geschichte - Denkmal. Zur Entstehung des Denkmalbewußtseins der bürgerlichen Gesellschaft, Frankfurt a. M., New York 1987.

LLEWELLYN, Nigel, Honour in life, death, and in the memory. Funeral monuments in early modern England, in: TRHS 6 (1996), $6^{\text {th }}$ ser. S. 179-200.

LOEWEN, James W., Lies across America. What our historic sites get wrong, New York 2000.

LOTTES, Günther ( $\mathrm{Hg}$.), Region, Nation, Europa. Historische Determinanten der Neugliederung eines Kontinents, Heidelberg, Regensburg 1992.

-, Zur Einführung: Staat, Nation, Region - Zu den Prinzipien der Formationsgeschichte Europas, in: LOTTES (Hg.), Region, S. 10-43. 
LOYER, François, Le Sacré-Cœur de Montmartre in: NORA (Hg.), Les Lieux III, Bd. 3, S. $450-473$.

LOYRETTE, Henri, La Tour Eiffel, in: NORA, Les lieux III, Bd. 3, S. 474-505.

LURZ, Meinhold, Kriegerdenkmäler in Deutschland, Bd. 1: Befreiungskriege, Bd. 2: Einigungskriege, Bd. 3: Erster Weltkrieg, Heidelberg 1985.

-, Erhalt der Aura trotz technischer Reproduktion. Berliner Künstler arbeiten für die WMF, in: BLOCH, EINHOLZ, VON SIMSON (Hg.), Ethos und Pathos, S. 325-336.

LUUSEBRINK, Hans-Jürgen, Rolf REICHARDT, Die Bastille. Zur Symbolgeschichte von Herrschaft und Freiheit, Frankfurt 1990.

MAAS, Annette, Kriegerdenkmäler und Gedenkfeiern um Metz. Formen und Funktionen kollektiver Erinnerung in einer Grenzregion (1870/71-1918), in: Rainer HUDEMANN, Rolf WITTENBROCK ( $\mathrm{Hg}$.), Stadtentwicklung im deutsch-französisch-luxemburgischen Grenzraum (19. und 20. Jahrhundert), Saarbrücken 1991, S. 89-118.

-, Zeitenwende in Elsaß-Lothringen. Denkmalstürze und Umdeutungen der nationalen Erinnerungslandschaften in Metz (November 1918-1922), in: Winfried SPEITKAMP (Hg.), Denkmalsturz. Zur Konfliktgeschichte politischer Symbolik, Göttingen 1997, S. 79-108.

MAAZ, Bernhard, Denkmalverständnis und Denkmalpflege im 19. Jahrhundert am Beispiel der Generalsstandbilder vom Wilhelmplatz, in: JbPK 34 (1997) S. 237-260.

MACE, Rodney, Trafalgar Square. Emblem of Empire, London 1976.

MACHTAN, Lothar, Bismarck-Kult und deutscher National-Mythos 1890-1914, in: DERS. (Hg.), Bismarck und der deutsche Nationalmythos, Bremen 1994, S. 15-67.

MACINTYRE, Angus, Lord George Bentinck and the Protectionists, in: TRHS $5^{\text {th }}$ s. 39 (1989) S. 141-165.

MACKENZIE, John M. (Hg.), Popular imperialism and the military 1850-1950, Manchester 1992.

-, Popular imperialism and the military, in: DERS. (Hg.), Popular imperialism, S. 1-24.

-, Heroic myths of empire, in: DERS. (Hg.), Popular imperialism, S. 109-137.

-, European Imperialism: Comparative Approaches, in: EHQ 22 (1992) S. 415-429.

- (Hg.), Imperialism and popular culture, Manchester 1992.

-, Propaganda and Empire. The manipulation of British Public Opinion, 1880-1960, Manchester 1984, ND 1997.

-, Imperial propaganda societies and imperial studies, in: DERS., Propaganda and Empire, S. 147-172.

-, The vehicles of imperial propaganda, in: DERS., Propaganda and Empire, S. 16-38

-, Empire and national identities. The case of Scotland, in: TRHS $6^{\text {th }}$ s. 8 (1998) S. 215 231.

MACLEAN, Ian, Bourdieu's field of cultural production, in: French Cultural Studies 4 (1993) S. 283-289.

MACMASTER, Neil, The battle für Mousehold Heath 1857-1884: ‘Popular politics` and the Victorian Public Park, in: P\&P 127 (1990) S. 117-154.

Magnol-Malhache, Véronique, Patrick Chamouard, Denis Lavalle, Léon Gambetta: Un saint pour la République?, Paris 1996.

MAI, Ekkehard, Vom Bismarckturm zum Ehrenmal. Denkmalformen bei Wilhelm Kreis, in: DERS., SCHMIRBER (Hg.), Denkmal - Zeichen - Monument, S. 50-57.

-, Die Denkmäler im Kaiserreich, in: Winfried NERDINGER, DERS. (Hg.), Wilhelm Kreis. Architekt zwischen Kaiserreich und Demokratie 1873-1955, Berlin 1994, S. $29-43$.

-, Gisela SCHMIRBER (Hg.), Denkmal - Zeichen - Monument: Skulptur und öffentlicher Raum heute, München 1989.

-, Stephan WAETZOLDT (Hg.), Kunstverwaltung, Bau- und Denkmalpolitik im Kaiserreich, Berlin 1981 (Kunst, Kultur und Politik im deutschen Kaiserreich, 1).

MAI, Gunther (Hg.), Das Kyffhäuser-Denkmal 1896-1996. Ein nationales Monument im europäischen Kontext, Köln, Weimar, Wien 1997. 
MaINARDI, Patricia, Arts and politics in the Second Empire. The universal expositions of 1855 and 1867, New Haven, London 1987.

MANDLER, Peter, Against »Englishness«: English culture and the limits to rural nostalgia, $1850-1940$, in: TRHS $6^{\text {th }}$ ser. VII (1997) S. 155-175.

MANGAN, J. A., IThe grit of our forefathers. Invented traditions, propaganada and imperialism, in: MACKENZIE (Hg.), Imperialism and popular culture, S. 113-139.

MASH, Harold, Phantasies of the Public Sphere: Rethinking the Habermas of Historians, in: JMH 72 (2000) S. 153-182.

MASON, John, Monthly and Quarterly Reviews 1865-1914, in: BOYCE, CURRAN, WINGATE (Hg.), Newspaper History, S. 281-293.

MASON, T.W., Nineteenth century Cromwell, in: P\&P 40 (1968) S. 187-191.

MATERNA, Ingo, Wolfgang RIBBE (Hg.), Brandenburgische Geschichte, Berlin 1995.

MATSUDA, Matt K., The memory of the modem, New York, Oxford 1996.

MATTENKLOTT, Gert (Red.), Deutsche Nationaldenkmale 1790-1990, hrsg. v. Sekretariat für kulturelle Zusammenarbeit nichttheatertragender Städte und Gemeinden in NordrheinWestfalen, Gütersloh, Bielefeld 1993.

—, «Denk ich an Deutschland ...«. Deutsche Denkmäler 1790-1990, in: DERS. (Red.), Nationaldenkmale, S. 17-48.

MAURER, Michael, Feste und Feiern als historischer Forschungsgegenstand, in: HZ 253 (1991) S. 101-130.

MAY, Otto, Deutsch sein heißt treu sein. Ansichtskarten als Spiegel von Mentalität und Untertanenerziehung in der Wilhelminischen Ära (1888-1918), Hildesheim 1998 (Untersuchungen zu Kultur und Bildung, 1).

MAYEUR, Jean-Marie, Les débuts de la III' République, 1871-1898, Paris 1973, ND 1995.

MCGUIRE, Michael, Bismarck in Walhalla: Der Bismarckkult und die Politik der Nationalen Identität vom Kaiserreich bis zum Dritten Reich, in: Hermann REUTER, Heide REUTER, DERS. (Hg.), Otto von Bismarck. Spuren und Wirkungen, Lingen o.J. [1996], S. 139163.

MCWILLIAM, Neil, Von sMarat، bis ,Thermidor،. Die Interpretation der Revolution in der Dritten Republik in Frankreich, in: Gudrun GERSMANN, Hubertus KOHLE (Hg.), Frankreich 1871-1914. Die Dritte Republik und die Französische Revolution, Stuttgart 2002, S. 99-118.

MEES, Ludger, Der spanische "Sonderweg «. Staat und Nation(en) im Spanien des 19. und 20. Jahrhunderts, in: AfS 40 (2000) S. 29-66.

MEINECKE, Friedrich, Weltbürgertum und Nationalstaat. Studien zur Genesis des deutschen Nationalstaates, München, Berlin ${ }^{3} 1915$.

MELMAN, Billie, Claiming the Nation's Past: The invention of an Anglo-Saxon Tradition, in: JContH 26 (1991) S. 575-595.

MÉLONIO, Françoise, Les libéraux français et leur histoire, in: Siep STUURMAN (Hg.), Les libéralismes, la théorie politique et l'histoire, Amsterdam 1994, S. 35-46.

MIECK, Ilja (Hg.), Paris und Berlin in der Restaurationszeit (1815-1830). Soziokulturelle und ökonomische Strukturen im Vergleich, Sigmaringen 1996.

-, Horst MÓLLER, Jürgen Voss (Hg.), Paris und Berlin in der Revolution 1848, Sigmaringen 1995.

MrTCHELL, Allan, Nationalfeiertage im Vergleich: Deutschland, Frankreich und die USA, in: FRANÇOIS u.a. (Hg.), Nation und Emotion, S. 396-401.

MrTCHELl, Leslie G., Charles James Fox, Oxford 1992.

MITTIG, Hans-Emst, Über Denkmalkritik, in: DeRS., PlagemanN (Hg.), Denkmäler, S. 283-301.

-, Volker Plagemann (Hg.), Denkmäler im 19. Jahrhundert. Deutung und Kritik (Studien zur Kunst des 19. Jahrhunderts, 20), München 1972. 
MOLlENHAUER, Daniel, Auf der Suche nach der »wahren Republik«. Die französischen »radicaux « in der frühen Dritten Republik (1870-1890), Bonn 1998 (Pariser Historische Studien, 46).

- À la recherche de la "vraie République«: quelques jalons pour une histoire du radicalisme des débuts de la Troisième République, in: RH 300 (1998) S. 579-615.

MOMMSEN, Wolfgang J., Die Verfassung des Deutschen Reiches von 1871 als dilatorischer Herrschaftskompromiß, in: DERS., Der autoritäre Nationalstaat. Verfassung, Gesellschaft und Kultur des deutschen Kaiserreichs, Frankfurt a.M. 1992, S. 39-65.

-, Kaisermacht und Bürgerstolz. Berlin als Hauptstadt des Kaiserreiches, in: Uwe SCHULTZ (Hg.), Die Hauptstädte der Deutschen: von der Kaiserpfalz in Aachen zum Regierungssitz Berlin, München 1993, S. 181-193.

-, Bismarck ließ verbreiten, die Engländerin habe eine Meise im Ohr, in: Frankfurter Allgemeine Zeitung, 4. August 2001, S. 42.

MOREL, Pierre, Les monuments des grands hommes. De la statue au modeste médaillon, o.O. 1991 .

MORRILL, John, The making of Oliver Cromwell, in: DERS. (Hg.), Oliver Cromwell, S. 1948.

- (Hg.), Oliver Cromwell and the English Revolution, London, New York 1990.

MORRIS, Marilyn, The British monarchy and the French Revolution, Binghamton, New York 1998.

MORROW, John, The paradox of Peel as Carlylean Hero, in: HJ 40 (1997) S. 97-110.

MOSSE, George L., Caesars, circuses, and Monuments, in: JContH 6/2 (1971) S. 167-182.

-, Die Nationalisierung der Massen. Politische Symbolik und Massenbewegungen von den Befreiungskriegen bis zum Dritten Reich, Frankfurt a. M., New York 1993 [engl. The Nationalization of the Masses, 1975].

MULLLE, Henning, Krieg und Tod als Mittel der Politik - Denkmäler für Politiker, Feldherm, Gefallene, in: TRIER, WEYRES (Hg.), Kunst des 19. Jahrhunderts, S. 249-279.

MƯLLER, Jürgen, Die Stadt, die Bürger und das Denkmal im 19. Jahrhundert, in: Dieter HEIN, Andreas SCHULZ (Hg.), Bürgerkultur im 19. Jahrhundert. Bildung, Kunst und Lebenswelt, München 1996, S. 269-288.

MUNKLER, Herfried, Mythos und Nation, in: Vorträge der Bibliothek Warburg 1 (1996) S. $107-143$.

MUNSELl, F. Darrell, The Victorian Controversy surrounding the Wellington War Memorial. The Archduke of Hyde Park Corner, Lewiston, Queenston, Lampeter 1991.

MURAT, Achille, La colonne Vendôme, Paris 1970.

MUTHESIUS, Stefan, Some aspects of English architectural nationalism in the $19^{\text {th }}$ and early $20^{\text {th }}$ centuries, in: Anna KWILECKA, Francis AMES-LEWIS (Hg.), Art and National Identity in Poland and England, London 1996, S. 65-71.

NEWBURY, Colin, Great Britain and the partition of Africa 1870-1914, in: PORTER (Hg.), The nineteenth century, S. 624-650.

NICOLAI, Bernd, Das Nationaldenkmal für Kaiser Wilhelm I. auf der Schloßfreiheit, in: ENGEL, RIBBE (Hg.), Hauptstadt Berlin, S. 115-123.

NIELEBOCK, Henry, Berlin und seine Plätze, Potsdam 1996.

NIETHAMMER, Lutz, Kollektive Identität. Heimliche Quellen einer unheimlichen Konjunktur, Reinbek bei Hamburg 2000.

NIGEL Llewellyn, Honour in life, death, and in the memory: Funeral monuments in early modern England, in: TRHS 6, $6^{\text {th }}$ ser. (1996) S. 179-200.

NIPPERDEY, Thomas, Nationalidee und Nationaldenkmal in Deutschland im 19. Jahrhundert, in: HZ 206 (1968) S. 529-585

—, Der Kölner Dom als Nationaldenkmal, in: HZ 283 (1981) S. 595-613.

-, Deutsche Geschichte 1800-1866. Bürgerwelt und starker Staat, München 1983 
—, Auf der Suche nach der Identität: Romantischer Nationalismus, in: DERS., Nachdenken über die deutsche Geschichte: Essays, München 1986, S. 110-125.

-, Deutsche Geschichte, Bd. 1: Arbeitswelt und Bürgergeist, München ${ }^{3} 1993$.

NOLTE, Paul, Staatsbildung als Gesellschaftsreform: politische Reformen in Preußen und den süddeutschen Staaten 1800-1820, Frankfurt a. M., New York 1990.

NOLTENIUS, Rainer, Dichterfeiern in Deutschland. Rezeptionsgeschichte als Sozialgeschichte am Beispiel der Schiller- und Freiligrath-Feiern, München 1984.

-, Schiller als Führer und Heiland. Das Schillerfest als nationaler Traum von der Geburt des zweiten deutschen Kaiserreichs, in: DÚDING u.a. (Hg.), Öffentliche Festkultur, S. 237-257.

NORA, Pierre, Présentation, in: DERS. (Hg.), Les lieux I, S. VII-XIII.

-, Comment écrire l'histoire de France?, in: DERS. (Hg.), Les lieux III, Bd. 1, S. 11-32.

—, Zwischen Geschichte und Gedächtnis, Frankfurt a. M. 1998.

- (Hg.), Les lieux de mémoire, I. La République, Paris 1984; II. La Nation, Paris 1986, 3 Bände; III. Les France, Paris 1992, 3 Bände.

NORD, Philip, Social defence and conservative regeneration: the national revival, 19001914, in: TOMBS ( $\mathrm{Hg}$.), Nationhood, S. 210-228.

-, The Republican moment. Struggles for democracy in nineteenth century France, Cambridge/Mass., London 1995.

NowACK, Kurt, Protestantische Eliten. Aspekte eines Vergleichs zwischen Deutschland und Frankreich (1870/71-1918), in: Louis DUPEUX, Rainer HUDEMANN, Franz KNIPPING (Hg.), Eliten in Deutschland und Frankreich im 19. und 20. Jahrhundert. Strukturen und Beziehungen, Bd. 2, München 1996, S. 157-173.

NÜRNBERGER, Richard, Rauchs Friedrich-Denkmal historisch-politisch gesehen, in: JbPK 8 (1970) S. 115-124.

NUNGESSER, Michael, Das Denkmal auf dem Kreuzberg von Karl Friedrich Schinkel, Berlin 1987.

OBEYESEKERE, Gananath, The apotheosis of Captain Cook. European mythmaking in the Pacific, Princeton 1997.

OERGEL, Maike, The redeeming Teuton: nineteenth-century notions of the /Germanic in England and Germany, in: CUBITT (Hg.), Imagining nations, S. 75-91.

OLSEN, Donald J., The City as a work of art. London, Paris, Vienna; New Haven, London 1986.

ORY, Pascal, Une nation pour mémoire, 1889, 1939, 1989, Trois jubilés révolutionaires, Paris 1992.

OSTERHAMMEL, Jürgen, Sozialgeschichte im Zivilisationsvergleich. Zu künftigen Möglichkeiten komparativer Geschichtswissenschaft, in: GG 22 (1996) S. 143-164.

OTTOMEYER, Hans, Ein Städtevergleich. Staatsarchitekturen in Paris und München 17991848, in: Hans-Michael KÖNER, Katharina WEIGAND $(\mathrm{Hg}$.), Hauptstadt. Historische Perspektiven eines deutschen Themas, München 1995, S. 95-116.

Ozouf, Mona, L'École de la France. Essais sur la Révolution, l'Utopie, et l'Enseignement, Paris 1984.

—, Le Panthéon. L'École normale des morts, in: NORA (Hg.), Les Lieux I, S. 139-166 [dt.: DIES., Das Pantheon. Freiheit, Gleichheit, Brüderlichkeit. Zwei französische Gedächtnisorte, Berlin 1996, S. 7-38].

-, Danton, in: FURET, DIES. (Hg.), Dictionnaire critique, S. 247-257.

-, Marat, in: FURET, DIES. (Hg.), Dictionnaire critique, S. 278-285.

PANOFSKY, Erwin, Ikonographie und Ikonologie. Eine Einfuihrung in die Kunst der Renaissance, in: DERS., Sinn und Deutung in der bildenden Kunst (meaning in the Visual Arts), Köln 1975, S. 36-67.

Le Panthéon. Symbole des révolutions. De l'Église de la Nation au Temple des grands hommes, Paris 1989 (AK Paris). 
PAPENHEIM, Martin, Erinnerung und Unsterblichkeit. Semantische Studien zum Totenkult in Frankreich (1715-1794), Stuttgart 1992 (Sprache und Geschichte, 18).

PARET, Peter, Die Berliner Secession. Moderne Kunst und ihre Feinde im Kaiserlichen Deutschland, Berlin 1981.

—, Kunst als Geschichte. Kultur und Politik von Menzel bis Fontane, München 1990.

PARR, Rolf, Zwei Seelen wohnen, ach! in meiner Brust. Strukturen und Funktionen der Mythisienung Bismarcks 1860-1918, München 1992.

PARRY, Jonathan, The rise and fall of liberal government in Victorian Britain, New Haven, London 1993.

PastoureaU, Michel, Le coq gaulois, in: NORA (Hg.), Les lieux III, Bd. 3, S. 506-539.

PAULManN, Johannes, Germanismus` am englischen Hof, oder: Warum war Prinz Albert unpopulär?, in: Peter ALTER, Rudolf MUHS ( $\mathrm{Hg}$.$) , Exilanten und andere Deutsche in$ Fontanes London, Stuttgart 1996, S. 387-415.

-, Pomp und Politik. Monarchenbegegnungen in Europa zwischen Ancien Régime und Erstem Weltkrieg, Paderborn u.a. 2000.

-, Peripatetische Herrschaft, Deutungskontrolle und Konsum. Zur Theatralität in der europäischen Politik vor 1914, in: GWU 53 (2002) S. 444-461.

PEACOCK, John, The visual image of Charles I, in: CoRNS ( $\mathrm{Hg}$.), The royal image, S. 176239.

PEARCE, Malcolm, Geoffrey STEWART, British political History 1867-1990. Democracy and decline, London, New York 1992.

PEARS, lain, The Gentleman and the Hero: Wellington and Napoleon in the Nineteenth Century, in: Roy PORTER (Hg.), Myths of the English, Cambridge 1992, S. 216-236.

PENNY, N.B., The Whig cult of Fox in early nineteenth-century sculpture, in: P\&P 70 (1976) S. 94-105.

PETERS-SCHILDGEN, Susanne, »Monumentaler Kitsch«? Denkmäler im Spiegel der Karikatur des 19. und 20. Jahrhunderts, in: Gert MATTENKLOTT (Red.), Deutsche Nationaldenkmale, S. 137-151.

PHYSICK, John, The Wellington Monument, London 1970.

-, Prime Ministers in Westminster Abbey, in: Church Monuments 9 (1994) S. 93-106.

PICKERING, Paul A., Alex TYRRELL, The people's bread. A history of the Anti-Corn Law League, London 2000.

PILBEAM, Pamela M., Republicanism in nineteenth-century France, 1814-1871, Basingstoke 1995.

PINGEOT, Anne, Le rattachement des Tuileries au Louvre: Les palais de la gloire, in: La sculpture française au XIX ${ }^{e}$ siècle, Paris 1982 (AK Galeries nationales du Grand Palais), S. 183-191.

-, Le décor sculpté du Panthéon sous le Second Empire et la III ${ }^{e}$ République, in: Le Panthéon, S. 259-269.

PINOL, Jean-Luc, Le monde des villes au XIX ${ }^{e}$ siècle, Paris 1991.

PlaNERT, Ute (Hg.), Nation, Politik und Geschlecht. Frauenbewegung und Nationalismus in der Moderne, Frankfurt a. M., New York 2000.

-, Vater Staat und Mutter Germania: Zur Politisierung des weiblichen Geschlechts im 19. und 20. Jahrhundert, in: DIES. (Hg.), Nation, Politik und Geschlecht, S. 15-65.

-, Zwischen Partizipation und Restriktion. Frauenemanzipation und nationales Paradigma von der Aufklänung bis zum Ersten Weltkrieg, in: LANGEWIESCHE, SCHMIDT (Hg.), Föderative Nation, S. 387-428.

PLESSIS, Alain, De la fête impériale au mur des fédérés 1852-1871, Paris 1979 (Nouvelle Histoire de la France Contemporaine, 9).

PLOSE, Detlef (Red.), Der Berliner Dom. Geschichte und Gegenwart der Oberpfarr- und Domkirche zu Berlin, Berlin 2001. 
PÖLS, Werner, Bismarckverehrung und Bismarcklegende als innenpolitisches Problem der Wilhelminischen Zeit, in: Jahrbuch für die Geschichte Mittel- und Ostdeutschlands 20 (1971) S. 183-201.

PoGGe von StRANDMANN, Hartmut, Der Kaiser und die Industriellen. Vom Primat der Rüstung, in: RÖL (Hg.), Der Ort Kaiser Wilhelms II., S. 111-129.

POIRRIER, Philippe, Loïc VADELORGE, La statuaire provinciale sous la Troisième République. Une étude comparée: Rouen et Dijon, in: RHMC 42 (1995) S. 240-269.

POMMIER, Edouard, Discours iconoclaste, discours culturel, discours national, 1790-1794, in: Simone BERNARD-GRIFFITHS, Marie-Claude CHEMIN, Jean EHRARD (Hg.), Révolution française et "vandalisme révolutionnaire«. Actes du colloque international de Clermont-Ferrand, Paris 1992, S. 299-313.

PORT, Michael H. (Hg.), The Houses of Parliament, New Haven, London 1976.

PORTER, Andrew u.a. (Hg.), The nineteenth century, Oxford 1999 (The Oxford History of the British Empire, 3).

POSNER, Roland, Kultur als Zeichensystem. Zur semiotischen Explikation kulturwissenschaftlicher Grundbegriffe, in: Aleida ASSMANN, Dietrich HARTH (Hg.), Kultur als Lebenswelt und Monument, Frankfurt a.M. 1991, S. 37-74.

PRICE, Roger, The French Second Empire. An Anatomy of Political Power, Cambridge 2001.

Prost, Antoine, Les monuments aux morts. Culte républicain? Culte civique? Culte patriotique?, in: NORA (Hg.), Les Lieux I, S. 195-225.

—, Mémoires locales et mémoires nationales: les monuments de 1914-1918 en France, in: Guerres mondiales et conflits contemporains 167 (1992) S. 41-50.

-, The impact of war on French and German political cultures, in: HJ 37 (1994) S. 209217.

-, Sociale et culturelle, indissociablement, in: RIOUX, SIRINELLI (Hg.), Pour une histoire culturelle, S. 131-146.

- Jeanne à la fête. Identité collective et mémoire à Orléans depuis la Révolution Française, in: CHARLE u.a. (Hg.), La France démocratique, S. 379-395.

PROTHERO, Iorwerth, Chartism in London, in: P\&P 44 (1969) S. 76-105.

PUGH, Martin, The Tories and the people 1880-1935, Oxford 1985.

PUHLE, Hans-Jürgen, Theorien in der Praxis des vergleichenden Historikers, in: Jürgen KOCKA, Thomas NIPPERDEY (Hg.), Theorie und Erzählung in der Geschichte, München 1979, S. 119-136.

PYKETT, Lyn, Reading the periodical press: text and context, in: Laurel BRAKE, Aled JONES, Lionel MADDEN, Investigating Victorian Journalism, Houndmills 1990, S. 3-18.

QUINAULT, Roland, 1848 and Parliamentary Reform, in: HJ 31 (1988) S. 831-851.

-, The cult of the Centenary, c. 1784-1914, in: HR 71 (1998) S. 303-323.

RAGUSSIS, Michael, Figures of conversion. "The Jewish question « \& English national identity, Durham, London 1995.

RAUleT, Gérard, Die Hypothek des Sonderwegs, in: DERS. (Hg.), Historismus, Sonderweg und Dritte Wege, Frankfurt a. M. u.a. 2001 (Schriften zur politischen Kultur der Weimarer Republik, 5), S. 7-31.

RAUSCH, Helke, Monumentale Personifizienung und kultische Inszenierung nationaler Identitäten. Offentliche Denkmalfiguren in Paris und Berlin nach 1870/71, in: VON HIRSCHHAUSEN, LEONHARD (Hg.), Nationalismen in Europa, S. 267-287.

-, Kultdissens und umstrittene Mythen: der Pariser Totenkult um die Kommunarden 1871 aus vergleichender Perspektive, in: zeitenblicke 3 (2004), Nr. 1, URL: http://zeitenblicke. historicum.net/2004/01/rausch/index.html.

READ, Benedict, Victorian Sculpture, New Haven, London 1982.

READ, Donald, Peel and the Victorians, Oxford 1987. 
REARICK, Charles, Festivals in Modern France: The Experience of the Third Republic, in: JContH 12 (1977) S. 435-460.

RÉAU, Louis, Histoire du Vandalisme. Les monuments détruits de l'art français, Paris 1994.

REBÉRIOUX, Madeleine, Le Mur des Fédérés. Rouge, ssang cerché‘, in: NORA (Hg.), Les lieux I., S. 619-649.

—, La République radicale?, 1898-1914, Paris 1975, ND 1992

RECHENBERG, Helmut, Persönlichkeiten aus der Frühgeschichte der PhysikalischTechnischen Reichsanstalt: Werner von Siemens, Hermann von Helmholtz, Friedrich Kohlrausch und Emil Warburg, in: Wilhelm TREUE, Gerhard HILDEBRANDT (Hg.), Berlinische Lebensbilder, Bd. 1: Naturwissenschaftler, Berlin 1987 (Einzelveröffentlichungen der Historischen Kommission zu Berlin, 60), S. 45-60.

REICHARDT, Rolf, Einleitung, in: DERS., Eberhard SCHMIDT (Hg.), Handbuch politischsozialer Grundbegriffe in Frankreich 1680-1820, Heft1/2, München 1985, S. 39-148.

—, Für eine integrierte soziale Kulturgeschichte der Französischen Revolution durch Kommunikationssoziologie und historische Anthropologie, in: Reinhart KOSELLECK, DERS. (Hg.), Die Französische Revolution als Bruch des gesellschaftlichen Bewußtseins, München 1988 (Ancien Régime, Aufklärung und Revolution, 15), S. 673-84.

REICHARDT, Sven, Bourdieu für Historiker? Ein kultursoziologisches Angebot an die Sozialgeschichte, in: Thomas MERGEL, Thomas WELSKOPP (Hg.), Geschichte zwischen Kultur und Gesellschaft. Beiträge zur Theoriedebatte, München 1997, S. 71-93.

REICHHARDT, Hans J., Wahlen in Berlin 1809-1967. Ein Rückblick auf 160 Jahre Kommunalpolitik, Berlin 1970 (Berliner Forum, 7/70).

-, Die Enstehung der Verfassung von Berlin. Eine Dokumentation, Bd. 1, Berlin 1990.

REISENLEITNER, Markus, Kulturgeschichte auf der Suche nach dem Sinn. Überlegungen zum Einfluß poststrukturalistischer Theoriebildung auf moderne Kulturgeschichtsschreibung, in: Österreichische Zeitschrift für Geschichtswissenschaft 3 (1992) S. 7-30.

REUSSE, Felix, Das Denkmal an der Grenze seiner Sprachfähigkeit, Stuttgart 1995 (Sprache und Geschichte, 23).

REYNOLDS, Donald Martin (Hg.), »Remove not the ancient landmark «. Public monuments and moral values, Amsterdam 1996.

RHEIMS, Maurice, Nineteenth-century sculpture, New York 1977.

RIBBE, Wolfgang, Jürgen SCHMÄDEKE (Hg.), Berlin im Europa der Neuzeit. Ein Tagungsbericht, Berlin 1990 (Veröffentlichungen der Historischen Kommission zu Berlin, 75).

-, Berlin im Europa der Neuzeit: Nationale Hauptstadt und europäische Metropole, in: DERS., SCHMÄDEKE (Hg.), Berlin, S. 17-51.

- (Hg.), Geschichte Berlins, Band 2: Von der Märzrevolution bis zur Gegenwart, München 1987.

RICHARDS, Thomas, The image of Victoria in the year of jubilee, in: Victorian Studies 31 (1987) S. 7-32.

RIHA, Karl, Deutscher Michel. Zur literarischen und karikaturistischen Ausprägung einer nationalen Allegorie im 19. Jahrhundert, in: LINK, WŨLFING (Hg.), Nationale Mythen und Symbole, S. 146-171.

RIOUX, Jean-Pierre, Jean-François SIRINELLI (Hg.), Pour une histoire culturelle, Paris 1997.

RITTER, Gerhard, Staatskunst und Kriegshandwerk. Das Problem des >Militarismus in Deutschland, Bd. 1: Die altpreußische Tradition (1740-1890), München 1954.

ROBBINS, Keith, Nineteenth century Britain. England, Scotland, and Wales. The making of a Nation, Oxford 1989.

-, An imperial and multinational polity, 1832 - 1922, in: GRANT, STRINGER (Hg.), Uniting the Kingdom, S. 244-254.

-, Great Britain: identities, institutions, and the idea of Britishness, Harlow 1998.

ROBINSON, Ronald, John GALLAGHER, Africa and the Victorians. The official mind of Imperialism, London und Basingstoke 1978, ${ }^{2} 1983$. 
ROGERS, Jean Scott, How Cobden came to Camden Town, in: Camden History Review 9 (1981) S. 20-23.

ROHE, Karl, Politische Kultur und ihre Analyse. Probleme und Perspektiven der politischen Kulturforschung, in: HZ 250 (1990) S. 321-346.

RÖHL, John C. G. (Hg.), Der Ort Kaiser Wilhelms II. in der deutschen Geschichte, München 1991 (Schriften des Historischen Kollegs, Kolloquien, 17).

ROOWAN, Ries, Nationaldenkmäler zwischen Geschichte und Kunstgeschichte, in: AKG 78 (1996) S. 453-466.

ROSENZWEIG, R., The parks and the people: social history and the urban parks, in: JSocH 18 (1984) S. 289-295.

ROTH, François, La guerre de 1870, Paris 1990.

RoUGERIE, Jacques, Paris insurgé. La Commune de 1871, Paris 1995, ND 2000.

RoUleaU, Bernard, Paris: Histoire d'un espace, Paris 1997.

ROUMIEUX, André, Auguste Scheurer-Kestner (1833-1898), in: Drouin (Hg.), L'affaire, S. 277-281.

RUPP, Gerhard, Gips, Zink und Bronze - Berliner Vervielfältigungsfirmen im 19. Jahrhundert, in: BLOCH, EINHOLZ, vON SIMSON (Hg.), Ethos und Pathos, S. 337-351,

RYAN, Deborah S., Staging the imperial city: The Pageant of London, 1911, in: DRIVER, GLBERT (Hg.), Imperial cities, S. 117 135.

SAGARRA, Eda, Selbstbestimmung durch Fremdbestimmung. On the history of >Der deutsche Michel as a cartoon image in the Vormärz, in: KOOPMANN, LAUSTER (Hg.), Vormärzliteratur, Bd. 1, S. 281-292.

SAHLINS, Marshall, How »Natives« think, About Captain Cook for example, Chicago 1995.

SAMUEL, Raphael (Hg.), Patriotism: The making and unmaking of British National Identity, Bd. 1: History and Politics, Bd. 2: Minorities and Outsiders, Bd. 3: National Fictions, London 1989.

-, Introduction: Exciting to be English, in: DERS. (Hg.), Patriotism 1, S. XVIII-LXVII.

-, Introduction: The figures of national myth, in: DERS. (Hg.), Patriotism 3, XI-XXXVI.

-, Paul THOMPSON, Introduction, in: DERS. (Hg.), The myths we live by, London 1990, ND 1993 (History Workshop Series), S. 1-22.

SANSON, Rosemonde, La "Fête de Jeanne d'Arc« en 1894. Controverse et célébration, in RHMC 20 (1973) S. 144-162.

SARTORI, Giovanni, Compare why and how. Comparing, miscomparing and the comparative method, in: Mattei Dogan, Ali KaZANCIGL (Hg.), Comparing Nations. Concepts, strategies, substance, Oxford, Cambridge/Mass. 1994, S. 14-34.

SAB, Hans-Martin, Hegel feiern!, in: GRIMM, HERMAND (Hg.), Deutsche Feiern, S. 62-78.

SAUNDERS, Christopher, Ian R.SMTTH, Southem Africa 1795-1910, in: PORTER (Hg.), The nineteenth century, S. 597-623.

SAVILLE, John, 1848. The British State and the Chartist Movement, Cambridge 1987, ND 1990, S. 220-229.

SCHÄCHE, Wolfgang, Platz für die Macht. Der Spreebogen in Berlin-Tiergarten, in: Romana SCHNEIDER, Wilfried WANG (Hg.), Moderne Architektur in Deutschland, 1900-1950. Macht und Monument, Ostfildern-Ruit 1998, S. 33-51.

SCHARF, Helmut, Zum Stolze der Nation. Deutsche Denkmäler des 19. Jahrhunderts, Dortmund 1983.

SCHASER, Angelika: Paris - Berlin: Zur Problematik des Vergleichs zweier Metropolen, in: MIECK, Paris und Berlin, S. 295-308.

SCHELLACK, Fritz, Sedan- und Kaisergeburtstagsfeste, in: DUDING u.a. (Hg.), Öffentliche Festkultur, S. 278-297.

-, Nationalfeiertage in Deutschland von 1871-1945, Frankfurt a. M. u.a. 1990 (Europäische Hochschulschriften Reihe III. Geschichte und Hilfswissenschaften, Bd. 415). 
SCHENK, Frithjof Benjamin, Mental maps. Die Konstruktion von geographischen Räumen in Europa seit der Aufklärung, in: GG 28 (2002) S. 493-514.

SCHEUNER, Ulrich, Die Kunst als Staatsaufgabe im 19. Jahrhundert, in: MAI, WAETZOLDT (Hg.), Kunstverwaltung, S. 13-46.

SCHIEDER, Theodor, Typologie und Erscheinungsformen des Nationalstaates in Europa, in: HZ 202 (1966) S. 58-81.

-, Das deutsche Kaiserreich von 1871 als Nationalstaat, hg. von Hans-Ulrich WEHLER, Göttingen ${ }^{2} 1992$.

SCHIVELBUSCH, Wolfgang, Die Kultur der Niederlage. Der amerikanische Süden 1865 Frankreich 1871. Deutschland 1918, Berlin 2001.

SCHLIE, Ulrich, Die Nation erinnert sich. Die Denkmäler der Deutschen, München 2002

SCHMALE, Wolfgang, Europäische Geschichte als historische Disziplin. Überlegungen zu einer »Europäistik“, in: ZfG 46 (1998) S. 389-405.

SCHMITZ, Edgar, Das Trojanische Pferd und die Restauration. Die Auseinandersetzung um die Colonne de la Place Vendôme als Paradigma der gescheiterten Restauration, in: Gudrun GERSMANN, Hubertus KoHLE (Hg.), Frankreich 1815-1830. Trauma oder Utopie? Die Gesellschaft der Restauration und das Erbe der Revolution, Stuttgart 1993, S. 187195.

SCHMOLl gen. EISENWERTH, J. A., Rodins »Ehernes Zeitalter« und die Problematik Französischer Kriegerdenkmäler nach 1871, in: JEISMANN, KOSELLECK $(\mathrm{Hg}$.), Der politische Totenkult, S. 223-247.

SCHMOLL, Friedemann, Verewigte Nation. Studien zur Erinnerungskultur von Reich und Einzelstaat im württembergischen Denkmalkult des 19. Jahrhunderts, Tübingen, Stuttgart 1995 (Stuttgarter Studien, 8).

SCHNABEL, Franz, Die Denkmalkunst und der Geist des 19. Jahrhunderts, in: Die Neue Rundschau 50 (1939) S. 415-436 und wieder in: Heinrich LUTZ (Hg.), Franz Schnabel, Abhandlungen und Vorträge 1914-1965, Freiburg, Basel, Wien 1970, S. 134-150.

SCHNEDER, Mechthild, Denkmäler für Künstler in Frankreich. Ein Thema der Auftragsplastik im 19. Jahrhundert, Frankfurt a. M. 1977.

SCHNEIDER, Ute, Politische Festkultur im 19. Jahrhundert. Die Rheinprovinz von der französischen Zeit bis zum Ende des Ersten Weltkriegs (1806-1918), Essen 1995 (Düsseldorfer Schriften zur Neueren Landesgeschichte und zur Geschichte NordrheinWestfalens, 41).

-, Einheit ohne Einigkeit. Der Sedantag im Kaiserreich, in: Sabine BEHRENBECK, Alexander NUTZZENADEL ( $\mathrm{Hg}$.), Inszenierungen des Nationalstaats. Politische Feiem in Italien und Deutschland seit 1860/71, Köln 2000 (Kölner Beiträge zur Nationsforschung, 7), S. 27-44.

SCHNYDER, André, Der Dichter als Monument. Ein Kapitel aus der Geschichte der Rezeption Walthers von der Vogelweide, in: AKG 71 (1989) S. 395-429.

SCHOCH, Rainer, Das Herrscherbild in der Malerei des 19. Jahrhunderts, München 1975 (Studien zur Kunst des 19. Jahrhunderts, 23).

SCHOLLGEN, Gregor, Imperialismus und Gleichgewicht. Deutschland, England und die orientalische Frage 1871-1914, München ${ }^{2} 1992$.

SCHOTTLER, Peter, Sozialgeschichtliches Paradigma und historische Diskursanalyse, in: Jürgen FOHRMANN, Harro MUULLR (Hg.), Diskurstheorien und Literaturwissenschaft, Frankfurt a. M. 1988, S. 159-199.

-, Wer hat Angst vor dem »linguistic turn«?, in: GG 23 (1997) S. 134-151.

SCHREIBER, Christa, Das Berlinische Rathaus - Versuch einer Entstehungs- und Ideengeschichte, in: Ekkehard MAI, Jürgen PAUL, Stephan WAETZOLDT (Hg.), Das Rathaus im Kaiserreich. Kunstpolitische Aspekte einer Bauaufgabe des 19. Jahrhunderts, Berlin 1982 (Kunst, Kultur und Politik im deutschen Kaiserreich, 4), S. 91-149. 
SCHRODER, Hans-Christoph, Die Revolutionen Englands im 17. Jahrhundert, Frankfurt a. M. $1986,{ }^{2} 1990$.

SCHULTE, Regina, Der Aufstieg der konstitutionellen Monarchie und das Gedächtnis der Königin, in: HA 6 (1998) S. 76-103.

SCHULTZ, Heiner, Begriffsgeschichte und Argumentationsgeschichte, in: Reinhart KOSELLECK (Hg.), Historische Semantik und Begriffsgeschichte, Stuttgart 1979 (Sprache und Geschichte, 1), S. 43-74.

SCHULTZ, Helga, Mythos und Aufklärung. Frühformen des Nationalismus in Deutschland, in: HZ 263 (1996) S. 31-67.

SCHULZ, Sibylle, Denkmäler im Stadtbild Berlins. Geschichte und Erhaltung, in: Institut für Denkmalpflege, Arbeitsstelle Berlin (Hg.), Denkmale in Berlin und in der Mark Brandenburg, Weimar 1987, S. 88-105.

SCHULZE, Hagen, Staat und Nation in der europäischen Geschichte, München 1994, ND 1999.

SCHULZE, Winfried, Vom »Sonderweg « bis zur "Ankunft im Westen«. Deutschlands Stellung in Europa, in: GWU 53 (2002) S. 226-240.

SCOTT, David, National Icons: the semiotics of the French stamp, in: FrenchHSt 3 (1992) S. 215-234.

SEARLE, G. R., Critics of Edwardian Society: The case of the Radical Right, in: Alan O'DAY (Hg.), The Edwardian Age, London, Basingstoke 1979, S. 79-96.

SEIDEL, Emst, Grand Axe - Paris, in: ENGEL, RIBBE (Hg.): Via triumphalis, S. 131-145.

SEIER, Hellmut, Berlin und die deutsche Nation. Die Hauptstadt und ihr Modernisierungspotential im Bewußtsein der Deutschen, in: Berlin in Geschichte und Gegenwart. Jahrbuch des Landesarchivs Berlin, hg. v. H. J. ReICHHARDT, Berlin 1989, S. 33-52.

SELBMANN, Rolf, Versteinerte Poesie oder Verkehrshindernis? Zur Geschichte der Dichterdenkmäler in Deutschland, in: AKG 76 (1994) S. 365-388.

SELLIN, Volker, Mentalität und Mentalitätsgeschichte, in: HZ 241 (1985) S. 555-598.

-, Mentalitäten in der Sozialgeschichte, in: Wolfgang SCHEDER, DERS. (Hg.), Sozialgeschichte in Deutschland. Entwicklungen und Perspektiven im internationalen Zusammenhang, Bd. 3, Göttingen 1987, S. 101-122.

-, Nationalbewußtsein und Partikularismus in Deutschland im 19. Jahrhundert, in: Jan ASSMANN, Tonio HOLSCHER (Hg.), Kultur und Gedächtnis, Frankfurt a. M. 1988, S. 241-264.

-, Die Politik in der Neuzeit zwischen Konfessionalismus und Ideologisierung, in: Friedhelm HIITERHAUS, Michael ZOLLER (Hg.), Kirche als Heilsgemeinschaft - Staat als Rechtsgemeinschaft: Welche Bindungen akzeptiert das moderne Bewußtsein?, Köln 1993 (Veröffentlichungen der Hanns-Martin-Schleyer-Stiftung, 38), S. 65-72.

-, Napoleon auf der Säule der Großen Armee. Metamorphosen eines Pariser Denkmals, in: Christof DIPPER, Lutz KIINKHAMMER, Alexander NUTZENADEL (Hg.), Europäische Sozialgeschichte. FS für Wolfgang Schieder, Berlin 2000 (Historische Forschungen, 68), S. 377-402.

-, Die geraubte Revolution. Der Sturz Napoleons und die Restauration in Europa, Göttingen 2001.

SEWELL, William H. Jr., Geertz, Cultural systems, and history: from synchrony to transformation, in: Representations 59 (1997) S. 35-55.

-, Sind Kulturgeschichte und die vergleichende Methode vereinbar?, in: Comparativ 1 (1998) S. 90-94.

-, Eine Theorie des Ereignisses. Überlegungen zur )möglichen Theorie der Geschichte( von Marshall Sahlins, in: Andreas SUTER, Manfred HETTLING (Hg.), Struktur und Ereignis, Göttingen 2001 (GG Sonderheft, 19) S. 46-74. 
SHEEHAN, James J., The problem of the Nation in German History, in: DERS., Otto BUSCH (Hg.), Die Rolle der Nation in der deutschen Geschichte und Gegenwart, Berlin 1985, S. 3-20.

SHEPPARD, Francis, The crisis of London's Government, in: Roy MACLEOD (Hg.), David Owen: The Government of Victorian London 1855-1889. The Metropolitan Board of Works, the Vestries and the City Corporation, Cambridge/Mass., London 1982, S. $23-$ 46.

-, London and the Nation, in: TRHS $5^{\text {th }}$ ser. 35 (1985) S. 51-74.

SHERMAN, Daniel J., Monuments, mourning and masculinity in France after World War I, in: Gender \& History 8 (1996) S. 82-107.

SIEDER, Reinhard, Sozialgeschichte auf dem Weg zu einer historischen Kulturwissenschaft, in: GG 20 (1994) S. 445-468.

SIEMANN, Wolfram, Die deutsche Revolution von 1848/49, Frankfurt a. M. 1985, ND 1997.

- Die Revolution von 1848/49 zwischen Erinnerung, Mythos und Wissenschaft: 18481998, in: GWU 5/6 (1998) S. 272-281.

SIMON, Christian, Kaiser Wilhelm II. und die deutsche Wissenschaft, in: RÖL (Hg.), Der Ort Kaiser Wilhelms II., S. 91-110.

SIMON, Holger, Die Bildpolitik des preußischen Königshauses im 19. Jahrhundert. Zur Ikonographie der preußischen Königin Luise (1776-1810), in: WRJb 60 (1999) S. 231-262.

SiMONS, Katrin, Vom Triumph der Republik zur Apotheose Napoleons. Überlegungen zur Ikonographie der Revolution und des Konsulats am Beispiel einiger Gemälde von Jacques Louis David und Jacques Réattu, in: WRJb 43 (1982) S. 207-230.

SIMSON, Jutta von, Geschichte des Denkmals. Die plastischen Entwürfe, in: DEES., Das Berliner Denkmal für Friedrich den Großen. Die Entwürfe als Spiegelung des preußischen Selbstverständnisses, Berlin 1976, S. 7-26.

-, Das Denkmal der Königin Luise in Berlin. Ein Beitrag zur Luisenverehrung im 19. Jahrhundert, in: Lucius GRISEBACH, Konrad RENGER (Hg.), Festschrift für Otto von Simson zum 65. Geburtstag, Frankfurt a. M., Berlin, Wien 1977, S. 516-530.

SIRINELLI, Jean-François, Politische Kultur und nationale Emotionen, in: FrANÇOIS u.a. (Hg.), Nation und Emotion, S. 393-395.

SMTTH, Alan, The image of Cromwell in Folklore and Tradition, in: Folklore 79 (1968) S. $17-39$

SMTTH, Anthony D., State-Making and Nation-Building, in: John A. HALL (Hg.), States in History, Oxford u.a. 1986, S. 228-263.

-, The ,Golden Age and national renewal, in: Geoffrey HOSKING, George SCHÖPFLIN (Hg.), Myths and Nationhood, London 1997, S. 36-59.

-, Nationalism and modernism. A critical survey of recent theories of nations and nationalism, London, New York 1999, ND 2001.

SMTTH, Jeffrey R., The Monarchy versus the Nation: The »Festive Year 1913 in Wilhelmine Germany, in: German Studies Review 23 (2000) S. 257-274.

SMTH, T.B., In defence of privilege: The City of London and the challenge of municipal reform 1875-1890, in: Journal of Social History 27 (1993) S. 59-83.

SMrTH, Tori, >A grand work of noble conceptions: the Victoria Memorial and imperial London, in: DRIVER, GLBERT (Hg.), Imperial cities, S. 21-39.

SOBOUL, Albert, Sentiment religieux et cultes populaires pendant la Révolution, saintes patriotes et martyres de la liberté, in: Archives de Sociologie des Religions 2 (1956) S. 7387, wieder in: Annales Historiques de la Révolution Française 29 (1957) S. 193-213, [engl.: Religious feeling and popular cults during the French Revolution: spatriot saints and martyrs for liberty, in: Stephen WLSON (Hg.), Saints and their cults. Studies in religious Sociology, Folklore and History, Cambridge 1997, S. 217-232]. 
SÖSEMANN, Bernd, Der Verfall des Kaisergedankens im Ersten Weltkrieg, in: RÖHL (Hg.), Der Ort Kaiser Wilhelms II., S. 145-170.

Soulie, Michel, Histoire de la Presse. Dossier du Centre International d'Études pédagogiques de Sèvres, Sèvres 1983.

SPECK, W. A., The Monument, in: History Today 23 (1973) S. 664-668.

SPILMAN, Lyn, Nation and commemoration. Creating national identities in the United States and Australia, Cambridge 1997.

SPRENGER, Reinhard K., Die Jahnrezeption in Deutschland 1871-1933. Nationale Identität und Modernisierung, Schorndorf 1985 (Wissenschaftliche Schriftenreihe des Deutschen Sportbundes, 19).

SPRINGER, Peter, Schinkels Schloßbrücke in Berlin. Zweckbau und Monument, Frankfurt a. M., Berlin, Wien 1981.

SPRINGHALL, J.O., Lord Meath, Youth, and Empire, in: JContH 5 (1970) S. 97-111.

STAMBOLIS, Barbara, Nationalisierung trotz Ultramontanisierung oder: "Alles für Deutschland. Deutschland aber für Christus«. Mentalitätsleitende Wertorientierungen deutscher Katholiken im 19. und 20. Jahrhundert, in: HZ 269 (1999) S. 57-97.

-, Religiöse Festkultur. Tradition und Neuformierung katholischer Frömmigkeit im 19. und 20. Jahrhundert: Das Liborifest in Paderborn und das Kilianfest in Würzburg im Vergleich, Paderborn u.a. 2000 (Forschungen zur Regionalgeschichte, 38).

Stamm-KuHlmanN, Thomas, König in Preußens großer Zeit. Friedrich Wilhelm III., der Melancholiker auf dem Thron, Berlin 1992.

STEINMETZ, Willibald, Gemeineuropäische Tradition und nationale Besonderheiten im Begriff, Mittelklasser. Ein Vergleich zwischen Deutschland, Frankreich und England, in: Reinhart KOSELLECK, Klaus SCHREINER (Hg.), Bürgerschaft. Rezeption und Innovation der Begrifflichkeit vom Hohen Mittelalter bis ins 19. Jahrhundert, Stuttgart 1994 (Sprache und Geschichte, 22), S. 161-236.

STERNHELL, Zeev, La droite révolutionnaire, 1885-1914. Les origines françaises du fascisme, Paris 1978.

-, The political culture of nationalism, in: ToMBS (Hg.), Nationhood, S. 22-38.

STEVENSON, David, Cromwell, Scotland and Ireland, in: MORRILL (Hg.), Oliver Cromwell, S. $149-180$.

STOKES, Eric, The first century of British colonial rule in India: social revolution or social stagnation?, in: P\&P 58 (1973) S. 136-160.

STOKLUND, B., The role of the International Exhibitions in the construction of national cultures in the $19^{\text {th }}$ century, in: Ethnologia Europaea 24 (1994) S. 35-44.

STRACHAN, Hew, Militär, Empire und Civil Society: Großbritannien im 19. Jahrhundert, in: Ute FREVERT (Hg.), Militär und Gesellschaft im 19. und 20. Jahrhundert, Stuttgart 1997 (Industrielle Welt, 58), S. 78-93.

StrandmanN, Hartmut Pogge von, Der Kaiser und die Industriellen. Vom Primat der Rüstung, in: RÖHL (Hg.), Der Ort Kaiser Wilhelms II, S. 111-129.

STRUPP, Christoph, Erbe und Auftrag. Bürgerliche Revolutionserinnerung im Kaiserreich, in: HZ 270 (2000) S. 309-343.

STÜBIG, Heinz, Die Wehrverfassung Preußens in der Reformzeit. Wehrpflicht im Spannungsfeld von Restauration und Revolution 1815-1860, in: FOERSTER (Hg.), Die Wehrpflicht, S. 39-53.

STUMP, Wolfgang, Lutherstandbilder als Nationaldenkmäler. Streiflichter zur Geschichte des Konfessionalismus in Deutschland im 19. Jahrhundert, in: Saeculum 34 (1983) S. 138-147.

SUMMERS, Anne, Militarism in Britain before the Great War, in: History Workshop Journal 2 (1976) S. 104-123.

-, The character of Edwardian Nationalism: Three popular Leagues, in: KENNEDY, NiCHOLLS (Hg.), Nationalist and racialist movements, S. 68-87. 
—, Edwardian militarism, in: SAMUEL (Hg.), Patriotism, Bd. 1, S. 236-256.

SUTCLIFFE, Anthony, London and Paris: Capitals of the Nineteenth century, Leicester 1983 (The Fifth H. J. Dyos Memorial Lecture).

TACKE, Charlotte, Denkmal im sozialen Raum. Nationale Symbole in Deutschland und Frankreich im 19. Jahrhundert, Göttingen 1995 (Kritische Studien zur Geschichtswissenschaft, 108).

TALKENBERGER, Heike, Von der Illustration zur Interpretation: Das Bild als historische Quelle. Methodische Überlegungen zur Historischen Bildkunde, in: ZHF 21 (1994) S. 289-313.

TAYLOR, Alan J.P., The struggle for mastery in Europe, 1848-1918, Oxford ${ }^{9} 1990$.

TAYLOR, Anthony, Shakespeare and Radicalism: the uses and abuses of Shakespeare in nineteenth-century popular politics, in: HJ 45 (2002) S. 357-379.

-, Reynold's Newspaper, Opposition to Monarchy and the Radical Anti-Jubilee: Britain's Anti-Monarchist Tradition reconsidered, in: HR 68 (1995) S. 318-337.

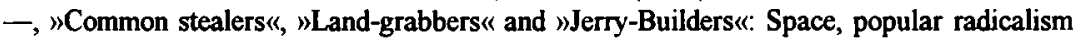
and the politics of public access in London, 1848-1880, in: International Review of Social History 40 (1995) 383-407.

TAYLOR, Miles, John Bull and the Iconography of Public Opinion in England c. 1712-1929, in: P\&P 134 (1992) S. 93-128.

-, The 1848 Revolutions and the British Empire, in: P\&P 166 (2000) S. 145-180.

-, The British Empire in the age of nationalism, 1815-1871, in: VON HIRSCHHAUSEN, LEONHARD (Hg.), Nationalismen in Europa, S. 117-132.

TELLENBACH, Gerd, Erinnern und Vergessen. Geschichtsbewußtsein und Geschichtswissenschaft, in: Saeculum 46 (1995) S. 317-329.

TENFELDE, Klaus, Adventus. Zur historischen Ikonologie des Festzuges, in: HZ 235 (1982) S. 45-84.

THADDEN, Rudolf von, Aufbau nationaler Identität. Deutschland und Frankreich im Vergleich, in: GIESEN (Hg.), Nationale und kollektive Identität, S. 493-512.

THOMPSON, Francis M.L. (Hg.), The Cambridge Social History of Britain, 1750-1950, Bd 1 : Regions and communities, Cambridge 1990.

THOMPSON, James, After the fall: class and political language in Britain, 1780-1900, in: HJ 39 (1996) S. 785-806.

TuLY, Charles, Big structures, large processes, huge comparisons, New York 1984.

TTTTEL, Lutz, Das Niederwalddenkmal 1871-1883, Hildesheim 1979.

-, Monumentaldenkmäler von 1871 bis 1918 in Deutschland. Ein Beitrag zum Thema Denkmal und Landschaft, in: MAI, WAETZOLDT (Hg.), Kunstverwaltung, S. 215-275.

TOMBS, Robert, Preface, in: DERS. (Hg.), Nationhood, XI-XV.

-, The political trajectory of Nationalism in nineteenth century France, in: VON HIRSCHHAUSEN, LEONHARD (Hg.), Nationalismen in Europa, S. 133-153.

- (Hg.), Nationhood and nationalism in France. From Boulangism to the Great War, 18891918, London, New York 1991.

TRÄGER, Jörg, Über die Säule der Großen Armee auf der Place Vendôme in Paris, in: DERS., Friedrich PEL (Hg.), FS Wolfgang Braunfels, Tübingen 1977.

-, Der Weg nach Walhalla. Denkmallandschaft und Bildungsreise im 19. Jahrhundert, Regensburg 1987, ${ }^{2} 1991$.

TREUE, Wilhelm, Christian Peter Wilhelm Friedrich Beuth, in: DERS., GRUNDER (Hg.), Berlinische Lebensbilder, Bd. 3, S. 119-134.

-, Karlfried GRUNDER (Hg.), Berlinische Lebensbilder, Bd. 3: Wissenschaftspolitik in Berlin. Minister, Beamte, Ratgeber, Berlin 1987 (Einzelveröffentlichungen der Historischen Kommission zu Berlin, 60).

TRIER, Eduard, Willy WEYRES (Hg.), Kunst des 19. Jahrhunderts im Rheinland, Bd. 4: Plastik, Düsseldorf 1980. 
TROYANSKY, David G., Monumental Politics: National History and Local Memory in French Monuments aux Morts in the Department of the Aisne since 1870, in: FrenchHSt 15 (1987) S. 121-141.

TRUESDELL, Matthew, Spectacular Politics. Louis-Napoléon Bonaparte and the Fête Impériale, 1949-1870, New York, Oxford 1997.

TULARD, Jean, Le retour des cendres, in: NORA (Hg.), Les lieux de mémoire II, Bd. 3, S. 81-110.

-, Frankreich im Zeitalter der Revolutionen, 1789-1851, Stuttgart 1989 (Geschichte Frankreichs, 4).

-, La vocation révolutionnaire de Paris, in: MIECK, MOLLER, VOSS (Hg.), Paris und Berlin, S. 15-18.

VALE, Lawrence J., Architecture, power, and national identity, New Haven und London 1992.

VALENSI, Lucette, Histoire nationale, histoire monumentale. Les lieux de mémoire (note critique), in: Annales 50 (1995) S. 1271-1277.

VALETTE, Jacques, L'expédition de Francis Garnier au Tonkin à travers quelques joumaux contemporains, in: RHMC 16 (1969) S. 189-220.

VERCRUYSSE, J., C'est la faute à Rousseau, c'est la faute à Voltaire, in: Studies on Voltaire in the eighteenth century 23 (1963) S. 61-76.

VIERHAUS, Rudolf, Wilhelm von Humboldt, in: TREUE, GRUNDER (Hg.), Berlinische Lebensbilder, Bd. 3, S. 63-76.

-, Die Rekonstruktion historischer Lebenswelten. Probleme moderner Kulturgeschichtsschreibung, in: Hartmut LEHMANN (Hg.), Wege zu einer neuen Kulturgeschichte, Göttingen 1995 (Göttinger Gespräche zur Geschichtswissenschaft 1), S. 7-28.

Vive la République 1792-1992, Paris 1992 (AK).

VOLCKER, Lars, Tempel für die Großen der Nation. Das kollektive Nationaldenkmal in Deutschland, Frankreich und Großbritannien im 18. und 19. Jahrhundert, Frankfurt a.M. 2000 (Europäische Hochschulschriften Reihe III, 877).

VOGEL, Barbara, Vom linken zum rechten Nationalismus. Bemerkungen zu einer Forschungsthese, in: WENDT (Hg.), Vom schwierigen Zusammenwachsen, S. 97-110.

VOGEL, Jakob, Nationen im Gleichschritt. Der Kult der Nation in Waffen in Deutschland und Frankreich, 1871-1914, Göttingen 1997 (Kritische Studien zur Geschichtswissenschaft, 118).

-, Nations in arms: military and commemorative festivals in Germany and France, 18711914, in: Karin FRIEDRICH (Hg.), Festive Culture in Germany and Europe from the sixteenth to the twentieth century, Lewiston, Queenston, Lampeter 2000, S. 245-264.

VOMM, Wolfgang, Denkmäler für Herrscher, in: TRIER, WEYRES (Hg.), Kunst des 19. Jahrhunderts, S. 213-247.

VOVELlE, Michel, La Marseillaise. La guerre ou la paix, in: NORA (Hg.), Les Lieux I, S. 85-136.

WAGNER, Monika, Allegorie und Geschichte. Ausstattungsprogramme öffentlicher Gebäude des 19. Jahrhunderts in Deutschland. Von der Cornelius-Schule zur Malerei der Wilhelminischen Ära, Tübingen 1989 (Tübinger Studien zur Archäologie und Kunstgeschichte, 9).

-, Selbstbegegnungen. Lebende Denkmäler in den Maifeiern der Sozialdemokratie um 1900, in: DiES. (Hg.), Mo(nu)mente, S. 93-112.

-, Outrages. Sculpture and kingship in France after 1789, in: Ann BERMINGHAM, John BREWER (Hg.), The consumption of culture, 1600-1800. Image, object, text, London New York 1995, S. 294-318.

WALKENHORST, Peter, Der ,Daseinskampf des Deutschen Volkes darwinismus und Imperialismus im wilhelminischen Deutschland, in: ECHTERNKAMP, MưlLER (Hg.), Die Politik der Nation, S. 131-148. 
WALLER, Philip J., Town, city, and nation. England 1850-1914, Oxford 1983, ND 1991.

WALTER, Eric, L'affaire La Barre et le concept d'opinion publique, in: Centre d'Études du XVIII ${ }^{\complement}$ siècle de l'Université Lyon III (Hg.), Le journalisme d'Ancien Régime. Questions et propositions. Table ronde CNRS 12-13 juin 1981, Lyon 1982, S. 361-392.

WALTER, Karin, Die Ansichtskarte als visuelles Massenmedium, in: Kaspar MAASE, Wolfgang KASCHUBA (Hg.), Schund und Schönheit. Populäre Kultur um 1900, Köln, Weimar, Wien 2001 (alltag \& kultur, 8), S. 46-61.

WALTER, Rodolphe, Un dossier délicat: Courbet et la colonne Vendôme, in: GBA 115 (1973) 173-184.

WARD, Paul, Red Flag and Union Jack. Englishness, patriotism and the british left, 18811924, London 1998.

WARWICK, Peter, Aftermath of war. Introduction, in: DERS., S.B. SPIES (Hg.), The South African War. The Anglo-Boer War 1899-1902, London 1980, S. 334-340.

WASHBROOK, D.A., India 1818-1860: the two faces of Colonialism, in: PORTER u.a. (Hg.), The nineteenth century, S. 395-421.

The Waterloo Directory of English Newspapers and Periodicals 1800-1900, 10 Bände, North Waterloo/Ontario 1997

WATSON, Nicola J., Gloriana Victoriana: Victoria and the cultural memory of Elizabeth I., in: HOMANS, MUNICH (Hg.), Remaking Queen Victoria, S. 79-104.

WEBER, Eugene, Peasants into Frenchmen. The modernization of rural France 1870-1914, London ${ }^{2} 1979$.

-, Gauls versus Franks: conflict and nationalism, in: ToMBS (Hg.), Nationalism, S. 8-21.

WEBER, Wilhelm, Luther-Denkmäler - Frühe Projekte und Verwirklichungen, in: MTTTIG, PlagemanN (Hg.), Denkmäler im 19. Jahrhundert, S. 185-215.

WEEKS, Theodore R., Monuments and memory: immortalizing count $\mathbf{M}$. N. Muraviev in Vilna, 1898, in: Nationalities Papers 27 (1999) S. 551-564.

WEHLER, Hans-Ulrich, Zur Funktion und Struktur der nationalen Kampfverbände im Kaiserreich, in: Werner CONZE, Gottfried SCHRAMM, Klaus ZERNACK (Hg.), Modernisierung und nationale Gesellschaft im ausgehenden 18. und im 19. Jahrhundert, Berlin 1979, S. 113-124.

-, Alltagsgeschichte. Königsweg zu neuen Ufern oder Irrgarten der Illusionen?, in: DERS., Aus der Geschichte lernen? Essays, München 1988, S. 130-151.

-, Deutsche Gesellschaftsgeschichte, Bd. 3: Von der "Deutschen Doppelrevolution $₫$ bis zum Beginn des Ersten Weltkrieges, 1849-1914, München 1995.

-, Rückblick und Ausblick - oder: arbeiten, um überholt zu werden?, in: Paul NOLTE, Manfred HeTtuING (Hg.), Perspektiven der Gesellschaftsgeschichte, München 2000, S. $159-168$.

-, Nationalismus. Geschichte, Formen, Folgen, München 2001.

WEILL, Georges (Hg.), La perspective de La Défense dans l'art et l'histoire, Nanterre 1983.

WEINLAND, Martina, Kriegerdenkmäler in Berlin 1870-1930, Frankfurt a. M. u.a. 1990 (Europäische Hochschulschriften, Reihe XXVIII, Kunstgeschichte, 105).

-, Kriegerdenkmäler in Berlin (1813/15 und 1914/18), in: BLOCH, EINHOLZ, VON SIMSON (Hg.), Ethos und Pathos, S. 281-291.

WEISBROD, Bernd, Der englische »Sonderweg« in die neuere Geschichte, in: GG 16 (1990) S. 233-252.

-, Philanthropie und bürgerliche Kultur. Zur Sozialgeschichte des viktorianischen Bürgertums, in: Hartmut BERGHOFF, Dieter ZEGLER (Hg.), Pionier oder Nachzügler? Vergleichende Studien zur Geschichte Großbritanniens und Deutschlands im Zeitalter der Industrialisierung, FS für Sidney Pollard, Bochum 1995 (ADEF-Veröffentlichungen, 28), S. 205-220.

WENDE, Peter, Probleme der englischen Revolution, Darmstadt 1980. 
WENDT, Bernd Jürgen, "Sonderweg" oder "Sonderbewußtsein«?, in: DERS. (Hg.), Vom schwierigen Zusammenwachsen, S. 111-141.

- (Hg.), Vom schwierigen Zusammenwachsen der Deutschen: nationale Identität und Nationalismus im 19. und 20. Jahrhundert, Frankfurt a. M. u.a. 1992.

WENG, Klaus, Rudolf Virchow und Emil du Bois-Reymond. Briefe 1864-1894, Marburg/Lahn 1995.

—, Rudolf Virchow und die Humboldt-Denkmäler vor der Berliner Universität, Berlin 1995, ${ }^{2} 1998$ (Berlin-Brandenburgische Akademie der Wissenschaften. Wissenschaftshistorische Manuskripte, 4).

WeSTFEHLING, Uwe, J. I. Hittorffs Pläne für ein Denkmalsforum in Paris, in: WRJb 36 (1974) S. 273-294.

WIENER, Deborah E.B., Architecture and social reform in late-Victorian London, Manchester 1994.

WIENFORT, Monika, Monarchie in der bürgerlichen Gesellschaft: Deutschland und England 1640-1848, Göttingen 1993 (Bürgertum, 4).

WILDEROTTER, Hans, Nationaldenkmäler. »Fern vom alltäglichen Gewühl ...«, in: Bodo Michael BAUMUNK, G. BRUNN (Hg.), Hauptstadt: Zentren, Residenzen, Metropolen in der deutschen Geschichte, Köln 1989 (AK Bonn), S. 297-301.

WILLIAMS, Richard, The contentious crown. Public discussion of the British monarchy in the reign of Queen Victoria, London 1997.

WILLMS, Johannes, Paris. Hauptstadt Europas 1789-1914, München 1988.

WINKLER, Heinrich August, Vom linken zum rechten Nationalismus. Der deutsche Liberalismus in der Krise von 1878/79, in: GG 4 (1978) S. 5-28.

-, Nationalismus, Nationalstaat und nationale Frage in Deutschland seit 1945, in: DERS., KAELBLE (Hg.), Nationalismus, S. 12-33.

-, Hartmut KAELBLE (Hg.), Nationalismus - Nationalitäten - Supranationalität, Stuttgart $1993,{ }^{2} 1995$ (Industrielle Welt, 53).

-, Der lange Weg nach Westen. Deutsche Geschichte vom »Dritten Reich « bis zur Wiedervereinigung, 2 Bände, München 2001.

WINOCK, Michel, Jeanne d'Arc, in: NORA (Hg.), Les lieux III, Bd. 3, S. 674-733.

-, Le mythe fondateur: l'affaire Dreyfus, in: Serge BERSTEI, Odile RUDELLE (Hg.), Le modèle républicain, Paris 1992, S. 131-146.

WINTER, Jay M., Sites of memory, sites of mourning. The Great War in European cultural history, Cambridge 1995, ND 1998 (Studies in the Social and Cultural History of Modern Warfare).

—, Paris, London, Berlin 1914-1918/19, in: DERS., ROBERT (Hg.), Capital cities at war, S. 3-24.

-, Jean-Louis ROBERT, Une recherche comparative: Berlin, Londres et Paris pendant la Guerre, in: Rainer HUDEMANN, François WALTER (Hg.), Villes et guerres mondiales en Europe au XX' siècle, Paris 1997, S. 29-48.

- (Hg.), Capital Cities at War. Paris, London, Berlin 1914-1919 (Studies in the Social and Cultural History of Modern Warfare), Cambridge 1997, ND 1999.

WIRSCHING, Andreas, Bürgertugend und Gemeininteresse. Zum Topos der »Mittelklassen « in England im späten 18. und frühen 19. Jahrhundert, in: AKG 72 (1990) S. 173-199.

-, Parlament und Volkes Stimme. Unterhaus und Öffentlichkeit im England des frühen 19. Jahrhunderts, Göttingen, Zürich 1990 (Veröffentlichungen des DHI London, 26).

-, Arbeiter und Arbeiterbewegung in Paris in vergleichender Perspektive, in: MIECK, MÖLLER, VOSS (Hg.), Paris und Berlin, S. 161-185.

WOHLLEBEN, Joachim, Wilhelm von Humboldt, in: ERBE (Hg.), Berlinische Lebensbilder, Bd. 4, S. 1-20.

WOLFRUM, Edgar, Geschichte als Waffe. Vom Kaiserreich bis zur Wiedervereinigung, Göttingen 2001. 
Wolgast, Eike, Absolutismus in England, in: Hans PATZE (Hg.), Aspekte des europäischen Absolutismus, Hildesheim 1979, S. 1-22.

WoOLF, Penelope, Symbol of the Second Empire: cultural politics and the Paris Opera House, in: Stephen DANIELS, Denis CosGROVE (Hg.), The Iconography of landscape. Essays on the symbolic representation, design and use of past environments, Cambridge 1988 (Cambridge Studies in Historical Geography, 9), S. 214-235.

WORDEN, Blair, The English reputations of Oliver Cromwell 1660-1900, in: William LAMONT (Hg.), Historical controversies and historians, London 1998, S. 35-48.

WÖRNER, Martin, Die Welt an einem Ort. Illustrierte Geschichte der Weltausstellungen, Berlin 2000.

WORTMAN, Richard, Statues of the Tsars and the Redefinition of Russia's Past, in: REYNOLDS (Hg.), Remove not the ancient landmark, S. 111-137.

WUUlLFING, Wulf, Karin BRUNS, Rolf PARR, Historische Mythologie der Deutschen: 17891918, München 1991.

-, Die heilige Luise von Preußen. Zur Mythisierung einer Figur der Geschichte in der deutschen Literatur des 19. Jahrhunderts, in: DERS., Jürgen LINK (Hg.), Bewegung und Stillstand in Metaphern und Mythen. Fallstudien zum Verhältnis von elementarem Wissen und Literatur im 19. Jahrhundert, Stuttgart 1984 (Sprache und Geschichte, 9), S. 233275.

YARRINGTON, Alison, The Commemoration of the Hero 1800-1864. Monuments to the British Victors of the Napoleonic Wars, New York, London 1988.

YATES, Frances A., Gedächtnis und Erinnem. Mnemotechnik von Aristoteles bis Shakespeare, Weinheim, Berlin ${ }^{4} 1994$, S. 11-31 [engl.: The Art of memory, London, Chicago 1966].

ZELLER, Joachim, Kolonialdenkmäler und Geschichtsbewußtsein. Eine Untersuchung der kolonialdeutschen Erinnerungskultur, Frankfurt a.M. 2000.

ZIEBURA, Gilbert, Interne Faktoren des französischen Hochimperialismus 1871-1914. Versuch einer gesamtgesellschaftlichen Analyse, in: DERS. (Hg.), Wirtschaft und Gesellschaft in Frankreich seit 1789, Gütersloh 1975, S. 282-330.

ZIEMANN, Benjamin, Sozialmilitarismus und militärische Sozialisation im deutschen Kaiserreich 1870-1914, in: GWU 53 (2002) S. 148-164. 